\title{
Opportunities and Challenges in Sustainable
}

\section{Treatment and Resource Reuse of Sewage}

\section{Sludge: A Review}

Abdul Raheem, ${ }^{a}$ Vineet Singh Sikarwar, ${ }^{a}$ Jun He, ${ }^{b}$ Wafa Dastyar, ${ }^{a}$ Dionysios D. Dionysiou, ${ }^{c}$ Wei Wang, ${ }^{a, d, e}$ and Ming Zhao, ${ }^{a, d, e, *}$

${ }^{\text {a }}$ School of Environment, Tsinghua University, Beijing, 100084, China

${ }^{b}$ Research Group of Natural Resources and Environment, International Doctoral Innovation Centre, Department of Chemical and Environmental Engineering, University of Nottingham Ningbo China, Ningbo, 315100, China.

${ }^{c}$ Environmental Engineering and Science Program, Department of Chemical and Environmental Engineering (ChEE), University of Cincinnati, OH, United States

${ }^{\mathrm{d}}$ Key Laboratory for Solid Waste Management and Environment Safety, Ministry of Education, Beijing, 100084, China

${ }^{\mathrm{e}}$ Beijing Engineering Research Center of Biogas Centralized Utilization, Beijing 100084, China

Corresponding Author

* Phone: +86 106278 4701; Email: ming.zhao@tsinghua.edu.cn 


\begin{abstract}
Sludge or waste activated sludge (WAS) generated from wastewater treatment plants may be considered a nuisance. It is a key source for secondary environmental contamination on account of the presence of diverse pollutants (polycyclic aromatic hydrocarbons, dioxins, furans, heavy metals, etc.). Innovative and cost-effective sludge treatment pathways are a prerequisite for the safe and environment-friendly disposal of WAS. This article delivers an assessment of the leading disposal (volume reduction) and energy recovery routes such as anaerobic digestion, incineration, pyrolysis, gasification and enhanced digestion using microbial fuel cell along with their comparative evaluation, to measure their suitability for different sludge compositions and resources availability. Furthermore, the authors shed light on the bio-refinery and resource recovery approaches to extract value added products and nutrients from WAS, and control options for metal elements and micro-pollutants in sewage sludge. Recovery of enzymes, bio-plastics, bio-pesticides, proteins and phosphorus are discussed as a means to visualize sludge as a potential opportunity instead of a nuisance.
\end{abstract}

KEYWORDS: Waste activated sludge, Anaerobic digestion, Thermochemical treatment, Bio-energy, Resources recovery, Sustainable management 


\section{INTRODUCTION}

Waste activated sludge (WAS) can simply be defined as the residual semi-solid material which is inevitably left over from municipal or industrial wastewater or sewage treatment processes. The rapid rise in population coupled with increasing industrialization has enhanced the production of sludge manifolds [1], which is speculated to increase further, in the near future. Engineering and design relative to wastewater treatment plants (WWTPs) encounters challenging issues related to processing, reuse and disposal of sludge [2].

Wastewater is usually treated via physical routes such as flotation, sedimentation, etc., chemical pathways such as flocculation, etc. and biological ways such as microbial treatment. In addition, wastewater treatment (WWT) processes are grouped into subsystems (for example, primary, secondary and tertiary treatments). The three-fold objectives are (i) to achieve the removal of contaminants, (ii) to ease the management of generated byproducts, and (iii) to meet the legislative standards about the quality of discharged water. As shown in Fig. 1, primary sludge is generated by post mechanical treatment after the primary stage whereas WAS is generated via biological treatment at secondary stage in WWTP. Usually WAS is used for resource recovery or energy generation. A typical WAS composition includes $59-88 \% \mathrm{w} / \mathrm{v}$ biodegradable organic matters (OMs), composed of $50-55 \% \mathrm{C}, 25-30 \% \mathrm{O}, 10-15 \% \mathrm{~N}, 6-10 \% \mathrm{H}$ with little amount of $\mathrm{P}$ and $\mathrm{S}[3]$. 


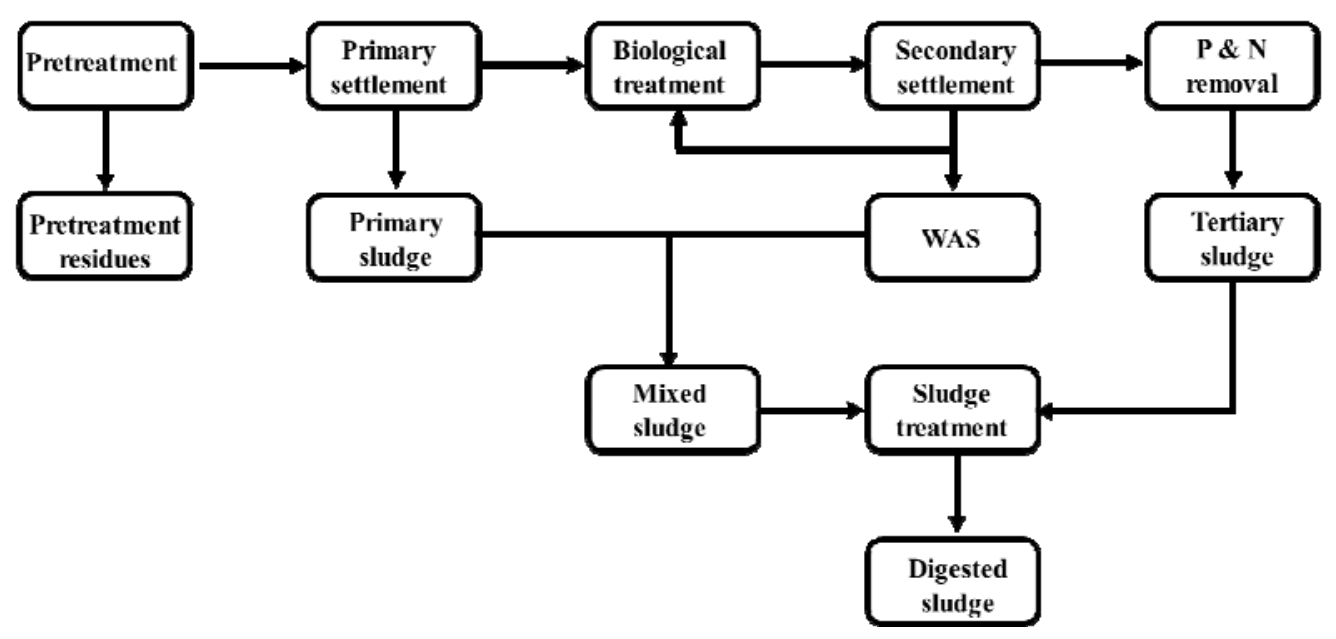

Fig. 1 Sludge generation in a WWTP [4].

Post-treatment WAS can be categorized as aerobic or anaerobic stabilized sludge. The structural composition, chemical properties and thermal behavior of WAS are the functions of stabilization techniques, engineering features of WWTP and pollution load of effluents. Sludge is an intricate blend of numerous materials such as OMs, inorganic matters, other substances, and microbes in dissolved or suspended states. Moreover, it also contains valuable inorganic ingredients such as $\mathrm{N}, \mathrm{P}, \mathrm{K}, \mathrm{Ca}, \mathrm{S}$ and $\mathrm{Mg}$, along with pollutants and potential carcinogens such as heavy metals (HMs), dioxins, furans, pathogenic microbes $[5,6]$. Bacterial constituents such as proteins, lipids, their decay products coupled with inorganic matter and cellulose form the chemical structure of a typical WAS [7].

WAS is the most vital by-product generated from WWTPs, whilst it causes human health problems as a potential source of secondary environmental pollution. Therefore, its proper disposal and treatment carries utmost significance. A diverse treatment range and valorization technologies are available for the safe disposal, resource recovery and power 
generation from WAS. Commonly used technologies for energy / resource recovery include anaerobic digestion (AD), incineration, pyrolysis and gasification [3]. In addition to nutrients ( $\mathrm{N}$ and $\mathrm{P}$ ), enzymes, bio-plastics, bio-pesticides and proteins can be recovered from WAS employing diverse techniques. Moreover, this perspective of biorefinery and resource recovery for WAS valorization will not only aid in holistic WAS management but will also lessen significant adverse environmental impact to a greater extent.

Thus, we have reviewed the scientific literature published on WAS treatment facilities during the last $5-7$ years. In spite of these facts, there is no single review on sewage sludge treatment with the emphasis on treatment technologies, energy recovery, bio-refinery approach for resource recovery as well as treatment scenarios in major countries such as EU, USA and China. We consider that, in all these respects, this is timely contribution. We expect that this review will encourage research and development work and may aid in the scale-up of conventional and advanced technologies. This review article is aimed at providing an overview and discusses the leading sludge treatment technologies (anaerobic digestion, incineration, pyrolysis, gasification and microbial fuel cell integrated process) and their comparative analysis. The coproduction of bio-refinery products from sewage sludge, resource recovery and pollution control for sewage sludge are also reviewed as an opportunity towards sustainable sludge management. An account of treatment scenarios for EU, USA and China is given, which is then followed by conclusions and future perspectives. 


\section{SEWAGE SLUDGE TREATMENT AND ENERGY RECOVERY}

Herein, anaerobic digestion (AD), incineration, pyrolysis, gasification and MFC integrated process are discussed as commonly employed routes for the safe treatment and energy recovery from WAS. There are some other pathways also such as wet air oxidation and hydrothermal treatment but they have very limited application and hence are not discussed here.

\subsection{Anaerobic digestion}

AD transforms sludge organic solids to biogas via the following biochemical reaction in an anaerobic condition (Eqn. 1).

$$
\mathrm{C}_{\mathrm{cHhO}} \mathrm{H}_{\mathrm{o}} \mathrm{N}_{\mathrm{s}}+\mathrm{yH}_{2} \mathrm{O} \rightarrow \mathrm{xCH} 4+\mathrm{nNH}_{3}+\mathrm{xH}_{2} \mathrm{~S}+(\mathrm{c}-\mathrm{x}) \mathrm{CO}_{2}
$$

where, $X=1 / 8(4 c+h-2 o-3 n-2 s)$ and $Y=1 / 4(4 c+h-2 o+3 n+3 s)$

Biogas comprises of $60-70 \%$ methane, and $30-40 \%$ of carbon dioxide, trace amounts of other gases (e.g. hydrogen, hydrogen sulfide and nitrogen), with a relative density of around 0.85 , and calorific value of about $13-21 \mathrm{MJ} \mathrm{kg}^{-3}$, which is lower than that of coal (15 - $\left.27 \mathrm{MJ} \mathrm{kg}^{-3}\right)$, but equivalent to lignite's $\left(12-16 \mathrm{MJ} \mathrm{kg}^{-3}\right)$ [8].

Apart from biogas, AD yields digestate as the final product containing high amounts of nutrients (e.g. phosphorus, potassium and nitrogen), which can be further utilized as fertilizer and/or compost.

Methane produced from WAS can be utilized for various applications such as gas engines, electricity and/or heat. The energy acquired via biogas is likely to cover $50 \%$ of the total operational cost of WWTP [9]. Currently, various parametric optimization studies were conducted to enhance the biogas yield and its quality (e.g. ratio of $\mathrm{CH}_{4}$ to $\mathrm{CO}_{2}$ ) [10-13]. Operating temperature is the most crucial parameter influencing the 
quantity and quality of the biogas and digestion rate. Three dissimilar temperature ranges, recognized as psychrophilic $\left(12-25^{\circ} \mathrm{C}\right)$, mesophilic $\left(35-38^{\circ} \mathrm{C}\right)$ and thermophilic $(50-$ $60{ }^{\circ} \mathrm{C}$ ), are applied depending on situations where the anaerobic fermentations occur, such as landfills, sediments, anaerobic digester [14]. Some studies have reported various biogas yields from AD of WAS $\left(270-385 \mathrm{~mL} \mathrm{CH}_{4} \mathrm{gVS}^{-1}\right)$ [15-17]. It is however known that OMs in WAS are immobilized; therefore, the OM hydrolysis or disintegration is known as rate-limiting step for the subsequent AD process [18]. Alternatively, various pretreatments such as thermal, chemical and mechanical have been applied to accelerate the conversion of persistent biomaterials present in WAS into soluble fractions, for which the main results are summarized in Table $1[10,12,19,20]$.

Compared to above pretreatments, post/inter-stage treatments are considered to be more advantageous for higher methane production [21, 22]. Nielsen et al. [21] compared different pretreatments such as moderate thermal, high thermal and thermochemical prior to $\mathrm{AD}$ with inter-stage treatments under the same experimental conditions as described in Table 1. They found thermal or thermochemical treatments of WAS more efficient when applied as inter-stage treatment rather than a pretreatment. The inter-stage treatment conditions $\left(170{ }^{\circ} \mathrm{C}, \mathrm{pH} 10, \mathrm{KOH}\right)$ led to improvement of methane yield by $28 \%$, whereas only $2 \%$ methane yield was improved using conventional pretreatment. A full-scale simulation showed that methane production would be improved by $45 \%$ using two anaerobic reactors with thermal inter-treatment, whilst only $20 \%$ improvement in methane production could be achieved using conventional AD and pretreatments [22]. More recently, a comprehensive study conducted by Campo et al. [23] demonstrated the low-temperature $\left(<100{ }^{\circ} \mathrm{C}\right)$ thermal and hybrid (thermal $+\mathrm{NaOH}$ and $\left.\mathrm{Ca}(\mathrm{OH})_{2}\right)$ 
intermediate and traditional pretreatments under the same experimental conditions. The intermediate treatments were found to be more efficient and produced $16 \%$ higher methane compared to traditional pretreatment, mainly due to their capability of utilizing a 7-day digestate for $\mathrm{AD}$ process. The economic assessment conducted in a commercial scale WWTP $(2,000,000$ population equivalent) revealed that thermal or hybrid pretreatments would probably augment the profits from the electricity sale between 13 to $15 \%$, when compared with the existing setup. On the other hand, intermediate treatments on a 7-day digestate would offer a revenue of $26 \%$ or $32 \%$, varying based on the operating temperature $\left(70\right.$ or $\left.90{ }^{\circ} \mathrm{C}\right)$. Albeit above methods could efficiently disintegrate WAS and promote methane production, almost all of them demand various chemical reagents and energy, which might be cost-intensive in application. Recently, Zhao et al. [19] (Table 1), utilized aged refuse (massively produced in landfills with high concentrations of enzymes and functional microorganisms) as a cost-effective alternative to accelerate the hydrolysis, solubilization and acidogensis mechanisms and has exhibited promising results. Considering the vast production of WAS, this approach should have considerable economic and ecological benefits if established at landfill sites. However, more studies to examine the potential role of $\mathrm{AR}$ in $\mathrm{AD}$ is urgently needed. Moreover, the applications of $\mathrm{AD}$ process at landfill sites will improve methane capture as fuel source for electricity generation and/or heat and also decrease $\mathrm{CO}_{2}$ emission from WWTPs operation. According to an analysis by United States Environmental Protection Agency (U.S.EPA), 2.3 million metric tons (Mt) of $\mathrm{CO}_{2}$ is released per annum (corresponding to the emissions by 430,000 automobiles) from WWTP. This amount could be counterbalanced, if existing WWTPs (with volume above 5 million gallons day ${ }^{-1}$ ) use AD 
technology for electricity production [24]. More recently, Kretschmer et al. [25] reported that in WWTPs in Austria provided with AD could attain electric independence under optimum operation of WWT and cogeneration. Thus, energy from biosolids in the form of biogas ensures energy security, a reduced dependence on fossil fuels, and lowered greenhouse gas (GHG) emissions. However, further research is required for the enhancement of energy recovery, process optimization towards energy independence using novel technologies such as the integration of solar energy with $\mathrm{AD}$ and Fuel Cell systems. 
Table 1. Summary of key information of WAS anaerobic digestion.

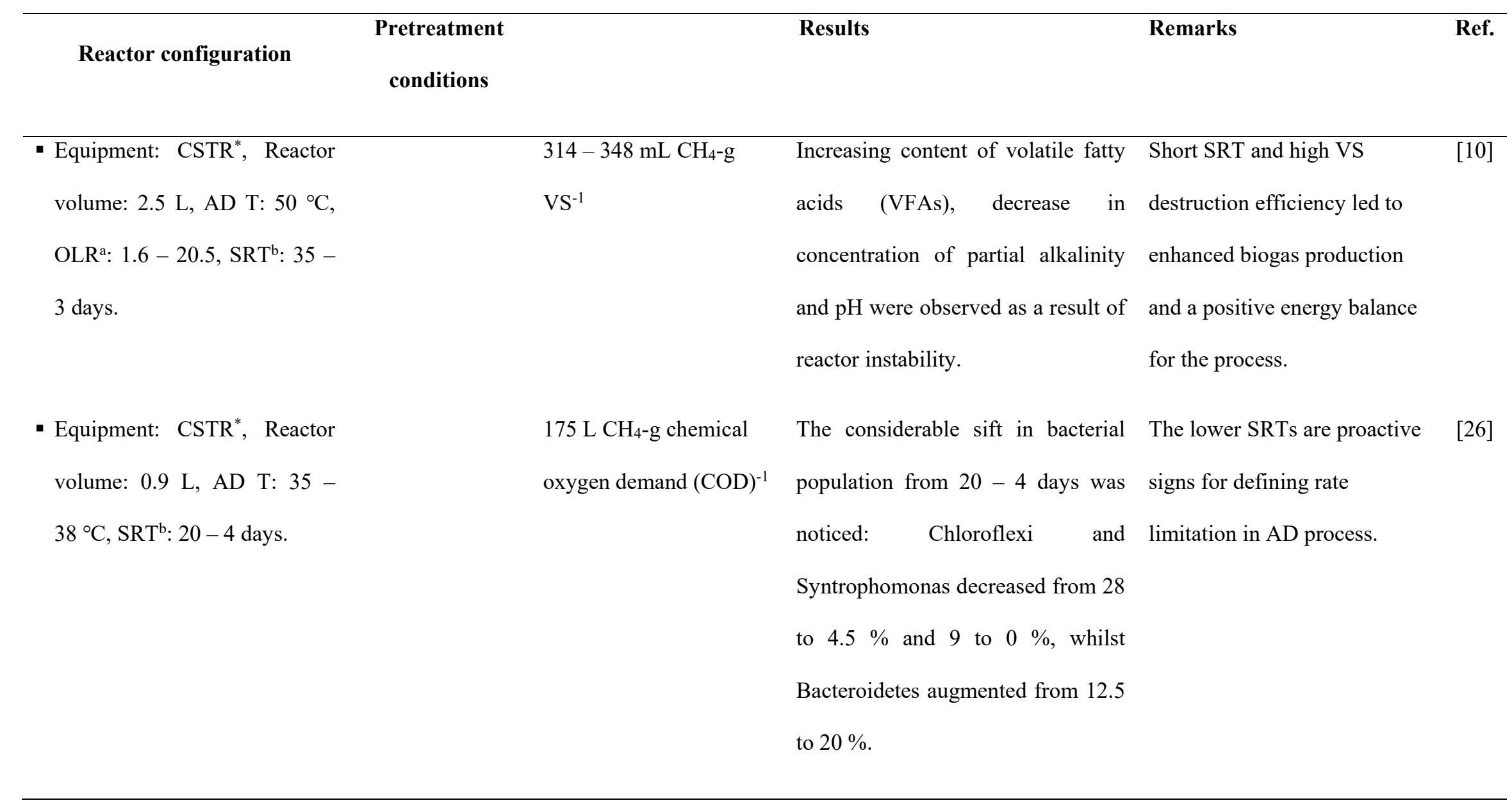




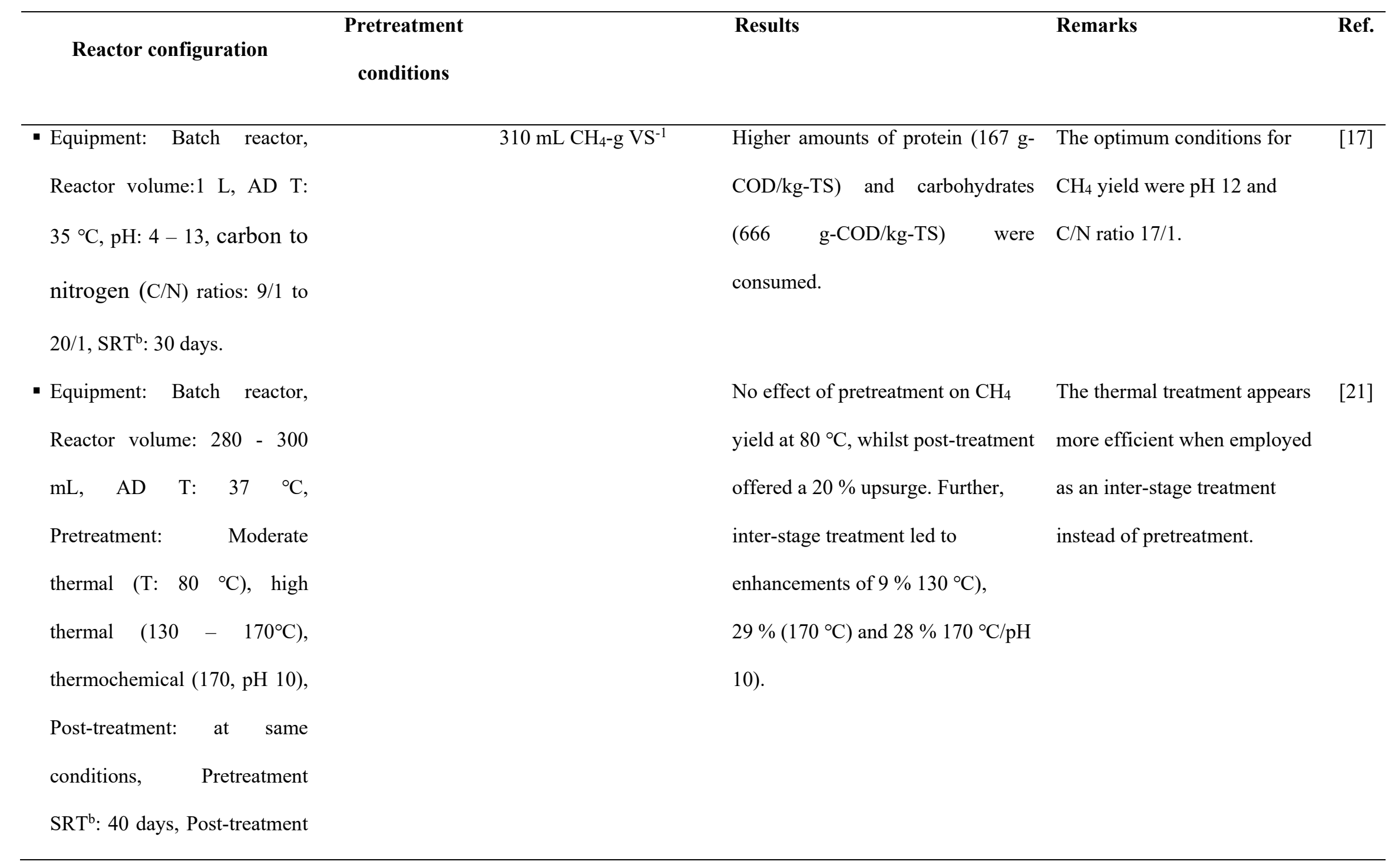




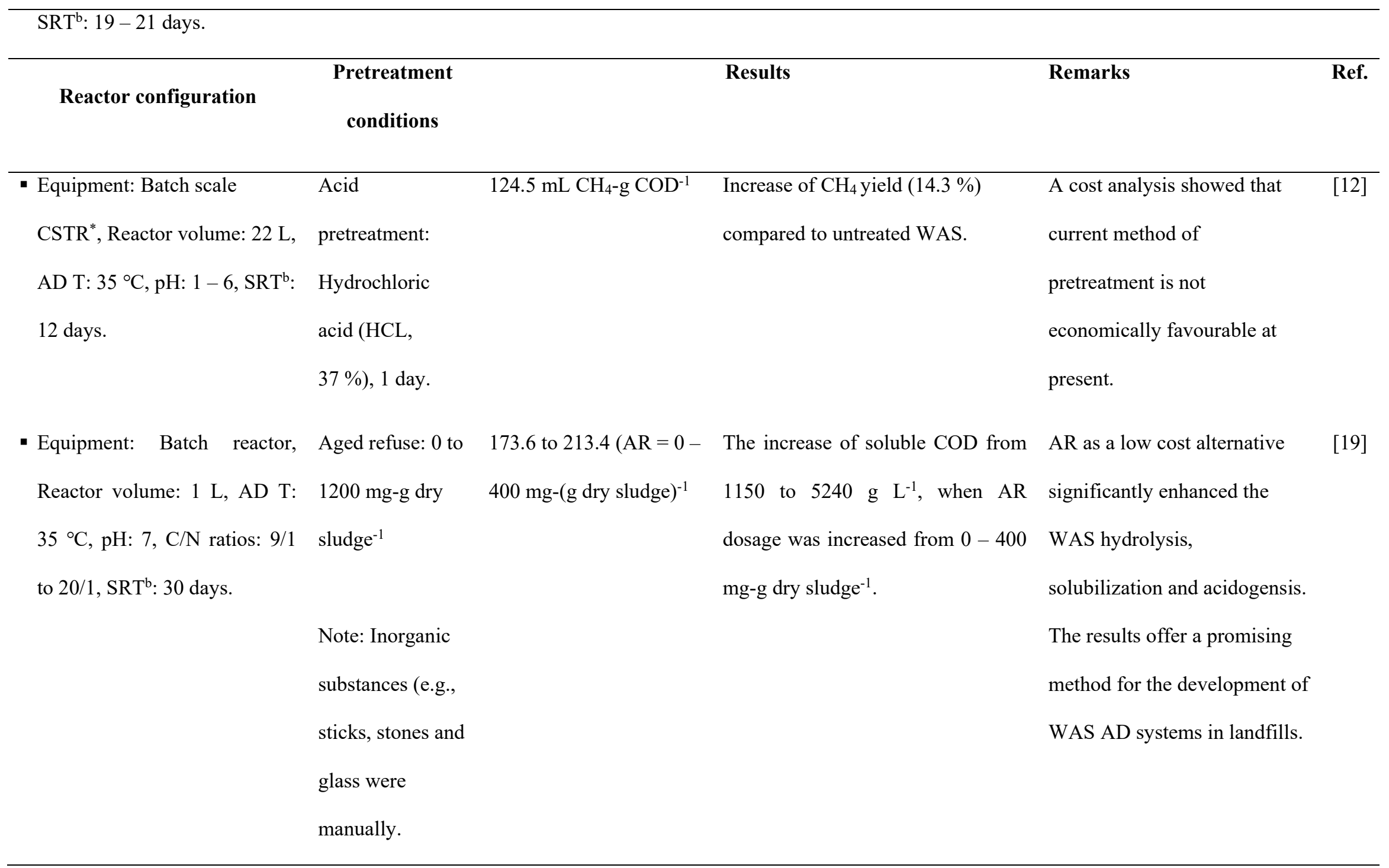




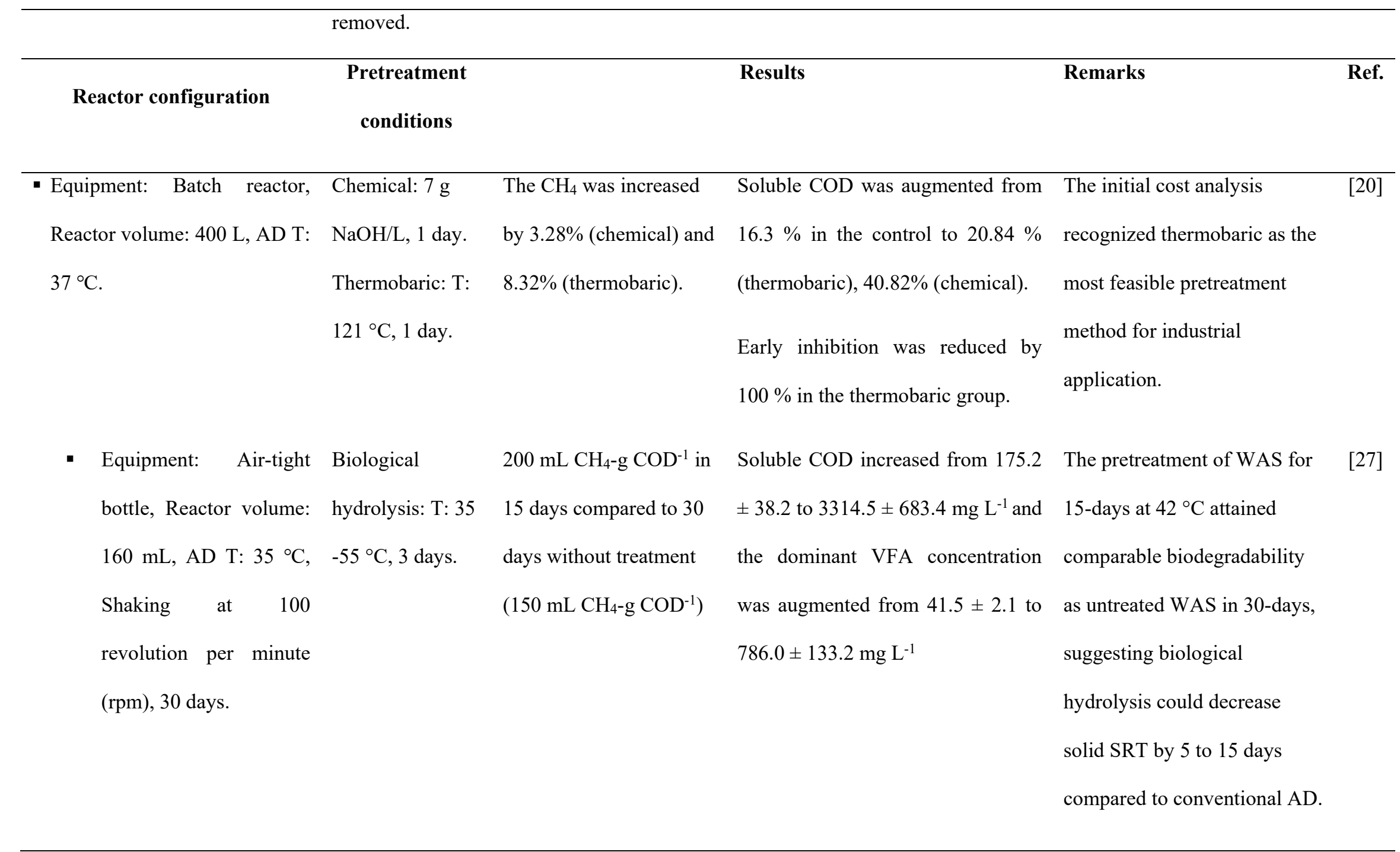




\begin{tabular}{|c|c|c|c|c|c|}
\hline Reactor configuration & $\begin{array}{c}\text { Pretreatment } \\
\text { conditions }\end{array}$ & & Results & Remarks & Ref. \\
\hline $\begin{array}{l}\text { Equipment: Batch reactor, } \\
\text { Reactor volume: } 125 \mathrm{~mL}, \mathrm{AD} \\
\mathrm{T}: 33^{\circ} \mathrm{C}, \mathrm{SRT}^{\mathrm{b}}: 18 \text { days. }\end{array}$ & $\begin{array}{l}\text { Microwave: } 50 \\
\text { to } 175{ }^{\circ} \mathrm{C} \text {. }\end{array}$ & $\begin{array}{l}\text { Increase of } \mathrm{CH}_{4} \\
\text { production }(>31 \%) \text {. }\end{array}$ & $\begin{array}{l}\text { Soluble COD increased from } 9 \\
\text { (unpretreated) to } 35 \% \text { as a result of } \\
\text { pretreatment. }\end{array}$ & $\begin{array}{l}\text { Inoculum acclimation } \\
\text { enhanced biogas yield as well } \\
\text { as the extent of ultimate } \\
\text { biodegradation of pretreated } \\
\text { WAS. }\end{array}$ & . \\
\hline $\begin{array}{l}\text { - Equipment: Batch reactor, } \\
\text { Reactor volume: } 25 \mathrm{~mL}, \mathrm{AD} \\
\text { T: } 35^{\circ} \mathrm{C}, \mathrm{SRT}^{\mathrm{b}}: 100 \text { days. }\end{array}$ & $\begin{array}{l}\text { Mechanical } \\
\text { (ultrasound): } 20 \\
\mathrm{kHz}, 0.33 \mathrm{~W} \mathrm{~mL}^{-} \\
\text {1, } 20 \mathrm{~min} .\end{array}$ & $\begin{array}{l}\mathrm{CH}_{4} \text { was increased from } \\
143 \text { (without treatment) } \\
\text { to } 292 \mathrm{~g} \mathrm{~kg}^{-1} \mathrm{TS}_{\text {in. }} .\end{array}$ & & $\begin{array}{l}\text { The existence of } \\
\text { polyelectrolyte flocculants } \\
\text { increased } \mathrm{CH}_{4} \text { yield during } \\
\text { first } 6 \text { days of digestion but } \\
\text { inhibited thereafter. }\end{array}$ & [29] \\
\hline
\end{tabular}

${ }^{*}$ Continuous stirred-tank reactor; ${ }^{\mathrm{a}}$ Organic loading rates $\left(\mathrm{kg} \mathrm{VS} \mathrm{m}^{-3}\right.$ day $\left.^{-1}\right)$; ${ }^{\mathrm{b}}$ Solid retention time 


\subsection{Incineration}

Incineration is an exothermic oxidation process of biosolids resulting in the flue gas comprising of $\mathrm{CO}_{2}$ and $\mathrm{H}_{2} \mathrm{O}$, ash and a certain amount of heat (Eqn. 2). Incineration reduces $90 \%$ sludge volume with the simultaneous destruction of pathogens. The residual ash (about 30 wt. \%) can be disposed into the landfills or to be utilized for building material production [30]. Whereas, the recovered heat produces steam, which is subsequently converted into power via steam turbines [3]

$$
\text { Biosolids / organics }+\mathrm{O}_{2} \text { (excess) } \rightarrow \mathrm{CO}_{2}+\mathrm{H}_{2} \mathrm{O}+\text { energy }+ \text { ash }
$$

Recently, incineration of WAS has gained great attention in several countries [7, 31] on the account of restricted application of WAS in arable land for food production [32, 33]. However, the augmented HMs quantities and the low P plant-accessibility is often related with incineration $[31,34]$. Therefore, several approaches are being developed to upgrade the incineration ashes or re-circulate WAS-P directly. Table 2 illustrates the operating conditions and results of several new methods such as thermal treatment with polyvinylchloride (PVC) and magnesium oxide ( $\mathrm{MgO})$ [35], acid leaching [36, 37], and electrodialysis [38, 39]. Thomsen et al. [40] (Table 2), reported that high content of total $\mathrm{P}$ retained in char and ash with the lower HMs per unit of $\mathrm{P}$ makes sludge as a potential source of P-fertilizer for agricultural systems. More discussion on $\mathrm{P}$ recovery from incineration is presented in Section 5. Recently, WAS incineration processes are increasingly established to recover the energy in the form of electric power or heat [4143].

The fluidized bed (FD) incinerators have been considered well efficient for WAS combustion in the form of dry or wet phase (with around $35-59$ wt. \% moisture content) 
with high combustion efficiency (e.g. lower organic fraction in the fly ashes $<0.3 \%$ ) and very low pollutants generation $\left(\mathrm{SO}_{\mathrm{x}}\right.$ and $\left.\mathrm{NO}_{\mathrm{x}}<200 \mathrm{mg} \mathrm{Nm}{ }^{-3}\right)$ [44]. Murakami et al. [41] successfully demonstrated WAS incineration in a unique FD incinerator (capacity $4.32 \mathrm{t}$ day $^{-1}$ ) provided with a turbocharger in Oshamanbe Cho in Hokkaido. Compared to conventional plants, less than half of emissions corresponding to $\mathrm{CO}, \mathrm{NO}_{\mathrm{x}}$, and $\mathrm{N}_{2} \mathrm{O}$ were observed in the flue gases. Nearly $50 \%$ of energy savings was estimated at incineration plant with capacity of $100 \mathrm{t}^{\text {day }^{-1}}$. Additionally, $\mathrm{CO}_{2}$ emission and the costs related to supplementary fuel and electricity consumption can be lowered by more than $40 \%$ and 0.2 million dollars, respectively. As reported by the National Association of Clean Water Agencies (NACWA), metro WWTP in St. Paul, Minnesota, U.S. has successfully installed incineration technology of 4.7 megawatt $\left(\mathrm{MW}_{\mathrm{e}}\right)$ electricity generation capacity. This plant has achieved approximately $20 \%$ of decrease in GHG emissions and about $\$ 1$ million savings each year [45]. Also, 0.2 and $0.8 \mathrm{MW}_{\mathrm{e}}$ incineration facilities are being established in Cleveland Ohio (U.S.) and in Hartford, Connecticut, respectively, which will substantially help to meet the energy requirement of plants [3, 45]. In another example, in Cyprus, Vassiliko cement plant, the sludge co-incineration with pet coke has successfully been employed [46]. The major advantages of WAS co-incineration in existing coal-based power plants can be summarized as below [47, 48]:

- To preclude the high cost of an incineration technology;

- To reduce the GHG emissions;

- To advance the energy retrieval efficacy as well as public acceptability.

In addition, low-caloric surplus heat of exhaust gases released from power plant can be effectively employed to enhance the sludge drying process [5]. Therefore, to ensure 
the simultaneous energy exploitation and efficient recovery of nutrients, further research is needed on the co-incineration of WAS with other feedstocks (such as coal, wood, etc.), the design of energy efficient incinerator, and the management of ashes with improved and optimized methods. 
Table 2. Summary of key information of WAS incineration.

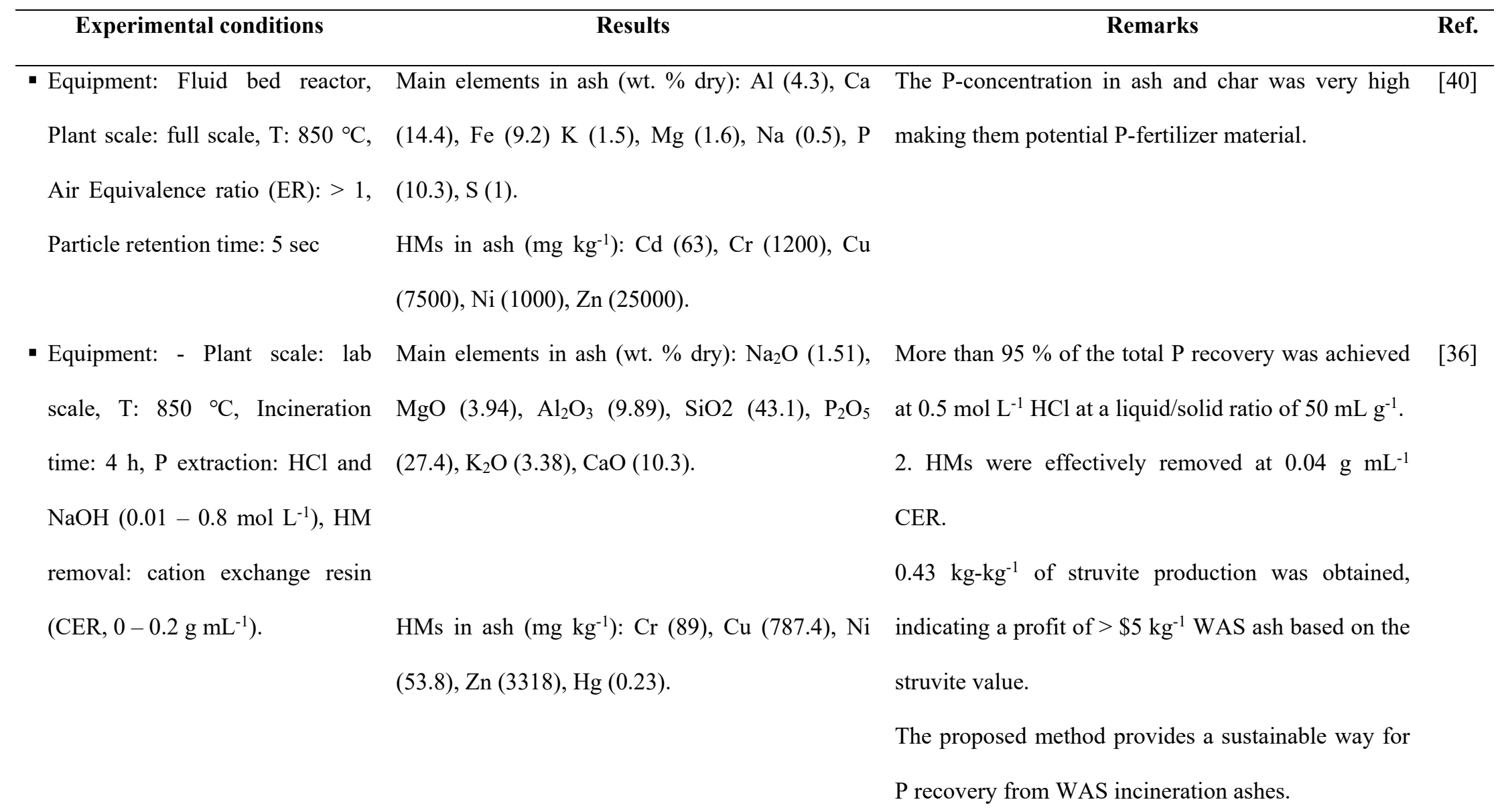




\begin{tabular}{|c|c|c|c|}
\hline Experimental conditions & Results & Remarks & Ref. \\
\hline $\begin{array}{l}\text { Equipment: Rotary furnace, Plant } \\
\text { scale: lab scale, T: } 800-950{ }^{\circ} \mathrm{C} \text {, } \\
\text { Air: } 5 \mathrm{~L} \mathrm{~min}{ }^{-1} \text {, Thermal treatment } \\
\text { for HMs removal: PVC and } \\
\text { MgO, Post-treatment: Chemical } \\
\text { (sulfuric and phosphoric acid). } \\
\text { Equipment: FD Incinerator, Plant } \\
\text { scale: Pilot scale, Ca-based bead } \\
\text { sorbents (SL-1 to SL-4) for } \\
\text { removal SO and particulate } \\
\text { matter (PM), T: } 850{ }^{\circ} \mathrm{C} \text {, Particle } \\
\text { retention time: } 6 \text { sec }\end{array}$ & $\begin{array}{l}\text { As }(1.1 / 1.3), \mathrm{Cd}(13.2 / 15.1), \mathrm{Cr}(266 / 288), \mathrm{Cu} \\
(480 / 522), \mathrm{Hg}(0.88 / 2.52), \mathrm{Pb}(144 / 180), \mathrm{Zn} \\
(2420 / 3245) \text {. }\end{array}$ & $\begin{array}{l}\text { SL-4 showed } 99 \% \text { removal efficiency for } \mathrm{SO}_{2} \text {, } \\
\text { probably due to higher specific surface area for } \\
\text { sorbent. } \\
\text { The collection of fine PM simultaneously eliminates } \\
\text { HMs WAS incineration. } \\
\text { The sorbent was found to be an effective material for } \\
\text { simultaneous removal of } \mathrm{SO}_{2} \text { and PM from WAS } \\
\text { incineration and therefore, it could be exploited for } \\
\text { industrial settings. }\end{array}$ & [49] \\
\hline - Equipment: & Gaseous products (\%): $\mathrm{H}_{2}(13.87), \mathrm{CO}(6.5), \mathrm{CO}_{2}$ & The combustible concentration in the fly ash & {$[50]$} \\
\hline
\end{tabular}




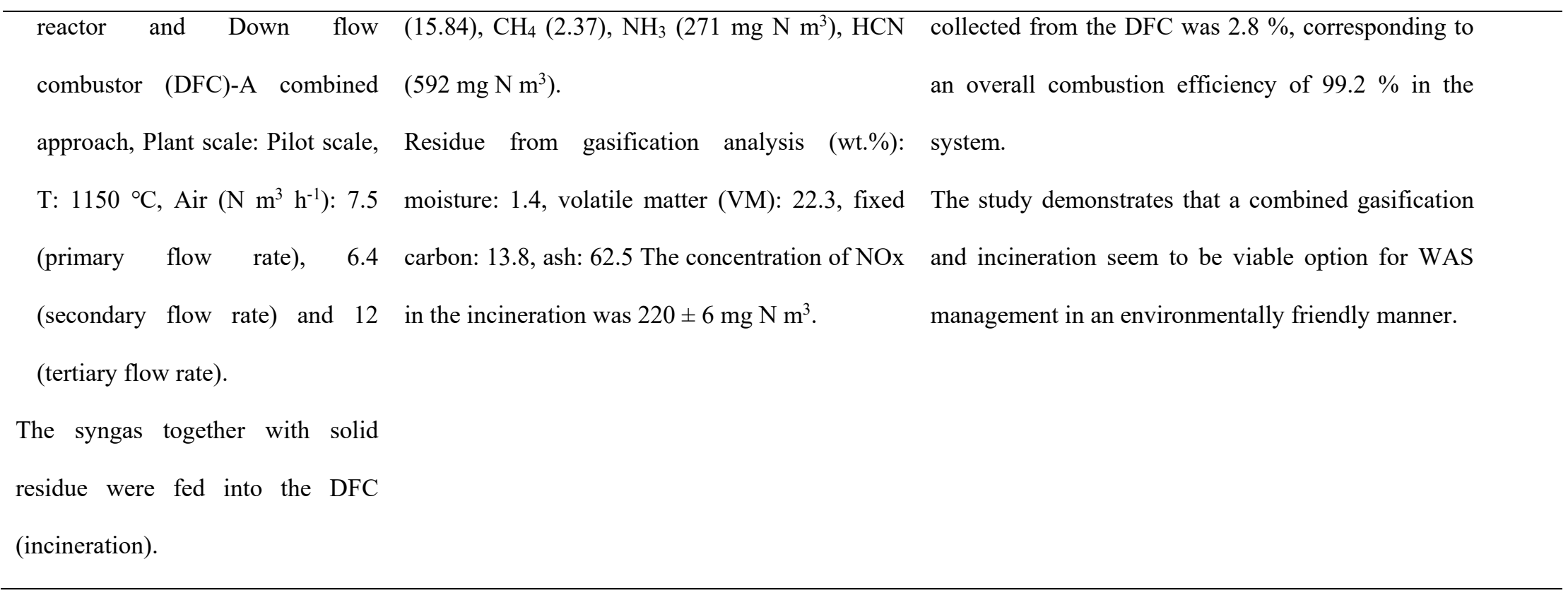




\subsection{Pyrolysis}

Pyrolysis is the thermal conversion $\left(350-900{ }^{\circ} \mathrm{C}\right)$ of WAS performed in an oxygen deficient environment generating vapors or pyrolytic gases. To separate the liquid or oil, the vapors need to be condensed through cooling, leaving behind a solid product namely char [51]. The quantity and quality of liquid, gas and char products depend on the process conditions including operating temperature, reaction time and pressure as well as the WAS characteristics.

Pyrolysis is generally characterized based on heating rate (HR), temperature, and gas residence time (GRT). A pyrolysis carried out at lower HR $\left(0.1-1{ }^{\circ} \mathrm{C} \mathrm{s}^{-1}\right)$, lower operating temperature $\left(300-400{ }^{\circ} \mathrm{C}\right)$, and higher GRT $(5-30 \mathrm{~min})$ is called slow pyrolysis. In contrary, fast pyrolysis takes place at higher $\mathrm{HR}\left(10-200{ }^{\circ} \mathrm{C} \mathrm{s}^{-1}\right)$, higher temperature $\left(450-600{ }^{\circ} \mathrm{C}\right)$, and a shorter GRT $(0.1-0.3 \mathrm{~s})$. Fast pyrolysis is a suitable approach for conversion of WAS to liquid or gaseous products. Carver-Greenfield technology (C-GT), Oil-from-Sludge technology (OFS) and the Siemens Schwell-Brenna technology (SSBT) are advanced applied pathways to generate renewable fuel (bio-oil) via pyrolysis of WAS [4]. C-GT uses the principle of multi-effect dehydration of waterbearing WAS and centrifugation to produce valuable products such as oil, animal feed and fertilizer $[52,53]$. OFS based pyrolysis enhances bio-oil production at $\sim 450{ }^{\circ} \mathrm{C}$ for over 30 min under atmospheric pressure to produce straight chain hydrocarbons, which are then condensed into oil [4]. SSBT includes co-pyrolysis of WAS and crushed wastes at $450{ }^{\circ} \mathrm{C}$ in a rotary kiln [54].

Compared to the highly exothermic incineration, most of the pyrolytic reactions are endothermic consuming energy of around $100 \mathrm{~kJ} \mathrm{~kg}^{-1}$ [55]. Table 3 shows the varying 
operating conditions and results of WAS pyrolysis carried out under various methods such as slow pyrolysis [56], fast pyrolysis [56-58], and microwave assisted [59] pyrolysis. As a result of using distinct technologies, operating conditions, and raw materials, WAS pyrolysis product characteristics and distribution differ noticeably. Atienza-Martínez et al. [58] (Table 3), reported a maximum liquid yield for anaerobically digested and thermally dried WAS fast pyrolysis $(32 \%)$ at $275{ }^{\circ} \mathrm{C}$ in $\mathrm{FD}$ reactor, when pretreatment (Torrefaction) and post-treatment (catalytic) were investigated. Gao et al. [60] investigated pyrolysis of dried WAS under the operating conditions described in Table 3, using a tubular reactor. They reported $46.14 \%$ of maximum tar yield at $550{ }^{\circ} \mathrm{C}$. One of the benefits of WAS pyrolysis is the low operating temperatures, thereby avoiding melting and evaporation of the HMs [4, 61-63]. Unlike incineration, WAS pyrolysis mainly yields a high amounts of char (approximately $50 \%$ of the mass of sludge), as shown in Table 3. These chars can be potentially used as solid fuel for heat or can be employed to adsorb HMs or organic contaminants [56]. Therefore, the emission of HMs into the environment triggering serious ecological and health effects could be significantly reduced [64]. Moreover, pyrolysis char has been explored as a cost-effective catalyst or catalyst support and an option for soil conditioning [65]. Nonetheless, the risk associated with the behavior of HMs contained in WAS pyrolysis char is still a serious concern, when considering its utilization or disposal.

Currently, several studies have been conducted mainly focusing on the distribution of HMs from pyrolysis of WAS. For instance, Gao et al. [56] studied the distribution of HMs in char and bio-oil produced from dried WAS under the experimental conditions presented in Table 3; it was noticed that most of the HMs were retained in the char, 
whilst very low concentration of HMs was observed in the bio-oil. HMs propensity in the char and the bio-oil were found to be comparable with the data reported by Trinh et al. [66], albeit the pyrolysis temperature was different. In addition, Jin et al. [67] (Table 3), suggested that majority of the HMs that accumulated in the char at $600{ }^{\circ} \mathrm{C}$ caused a major decline in bioavailability, indicating a tremendously low eco-toxicity/risk related to char subjected to the environment. Comparable results were also reported by Devi and Saroha [68] and Chen et al. [69], however different pyrolysis temperatures were used. The economic feasibility of pyrolysis is another challenging factor due to the relative complexity of processing equipment. However, it can be substantially supported by enhancing oil yields and production of high valued products from pyrolysis char [4]. The products produced from WAS such as oil, gas and char can be utilized for various application such as raw materials for producing chemicals and biofuel [4]. Moreover, pyrolysis flue gases also require lesser clean-up to satisfy emission limits than those from incineration. Samolada and Zabaniotou [70] compared WAS incineration, gasification and pyrolysis. Pyrolysis was identified as a zero waste technology, thus offering a potential solution to the pollution associated with WWT, compared to other technologies.

On the whole, it could be inferred that the technology of pyrolysis for WAS holds potential to satisfy the environmental criteria of sustainable development and economic and social concerns $[70,71]$. However, pyrolysis of WAS is still in infancy stages. Therefore, the introduction of more effective strategies (based on the type and content of HMs in the WAS) such as pre-/post-treatment, sorbents, and optimization of pyrolysis temperature towards high bio-oil production and the immobilization and/or minimization of HMs transfer to the products is needed. 
Table 3. Summary of key information of WAS pyrolysis.

\begin{tabular}{|c|c|c|c|}
\hline Experimental conditions & Results & Remarks & Ref. \\
\hline - Equipment: Horizontal tubular & Main elements in pyrolysis residue (wt. \% dry): Al (1.22), & Fast pyrolysis gave higher yield of tar & {$[60]$} \\
\hline furnace reactor, Plant scale: Lab- & $\mathrm{Ca}(1.79), \mathrm{Fe}(1.62) \mathrm{K}(1.5), \mathrm{Mg}(0.35), \mathrm{Na}(0.24), \mathrm{P}$ & compared to that of slow pyrolysis. & \\
\hline scale, Mode: slow pyrolysis $\left(8^{\circ} \mathrm{C}\right.$ & (4.3), and $\mathrm{S}$ (1.3). HMs in pyrolysis residue $\left(\mathrm{mg} \mathrm{kg}^{-1}\right): \mathrm{Cr}$ & With increasing temperature, total gas yield & \\
\hline $\left.\min ^{-1}\right)$ and fast pyrolysis $\left(100{ }^{\circ} \mathrm{C}\right.$ & (661), Ni (311), Mn (514), Ba (469), La (231), Ce (208), & increased and char decreased in both cases. & \\
\hline $\left.\min ^{-1}\right)$, Sludge loading: $120-200$ & and $\mathrm{Sr}(47)$. Tar yield (46.14 \%), Non-condensable gas & & \\
\hline g. & yield (28.64 \%), Char yield (47.07\%). & & \\
\hline - Equipment: FD reactor, Plant & Liquid yield (32\%), Non-condensable gas yield (21\%), & The combination of the treatments & {$[58]$} \\
\hline scale: $\quad$ Lab-scale, $\quad$ Sludge & Char yield (47 \%). & (torrefaction and catalytic) did not enhanced & \\
\hline pretreatment: Torrefaction $(\mathrm{T}$ : & & the properties of liquid for use as fuel, & \\
\hline $\left.250{ }^{\circ} \mathrm{C}, 13 \mathrm{~min}\right)$, Mode: Fast & & concerning $\mathrm{O} / \mathrm{C}$ molar ratio and nitrogen & \\
\hline pyrolysis, T: $250-275^{\circ} \mathrm{C}$, Sludge & & content. The treatment combination benefits & \\
\hline feeding rate: $<1 \mathrm{~kg} \mathrm{~h}^{-1}$, Hot & & were (i) the saving of catalyst ensuing from & \\
\hline pyrolysis vapors post-treatment: $\gamma-$ & & the lower quantity of vapors produced via the & \\
\hline $\mathrm{Al}_{2} \mathrm{O}_{3}$ catalyst (Auger reactor, $\mathrm{T}$ : & & pyrolysis torrefied WAS and (ii) the minor & \\
\hline $480{ }^{\circ} \mathrm{C}$, SRT: $\left.6.5 \mathrm{~min}\right)$ & & decline in the coke yield. & \\
\hline
\end{tabular}




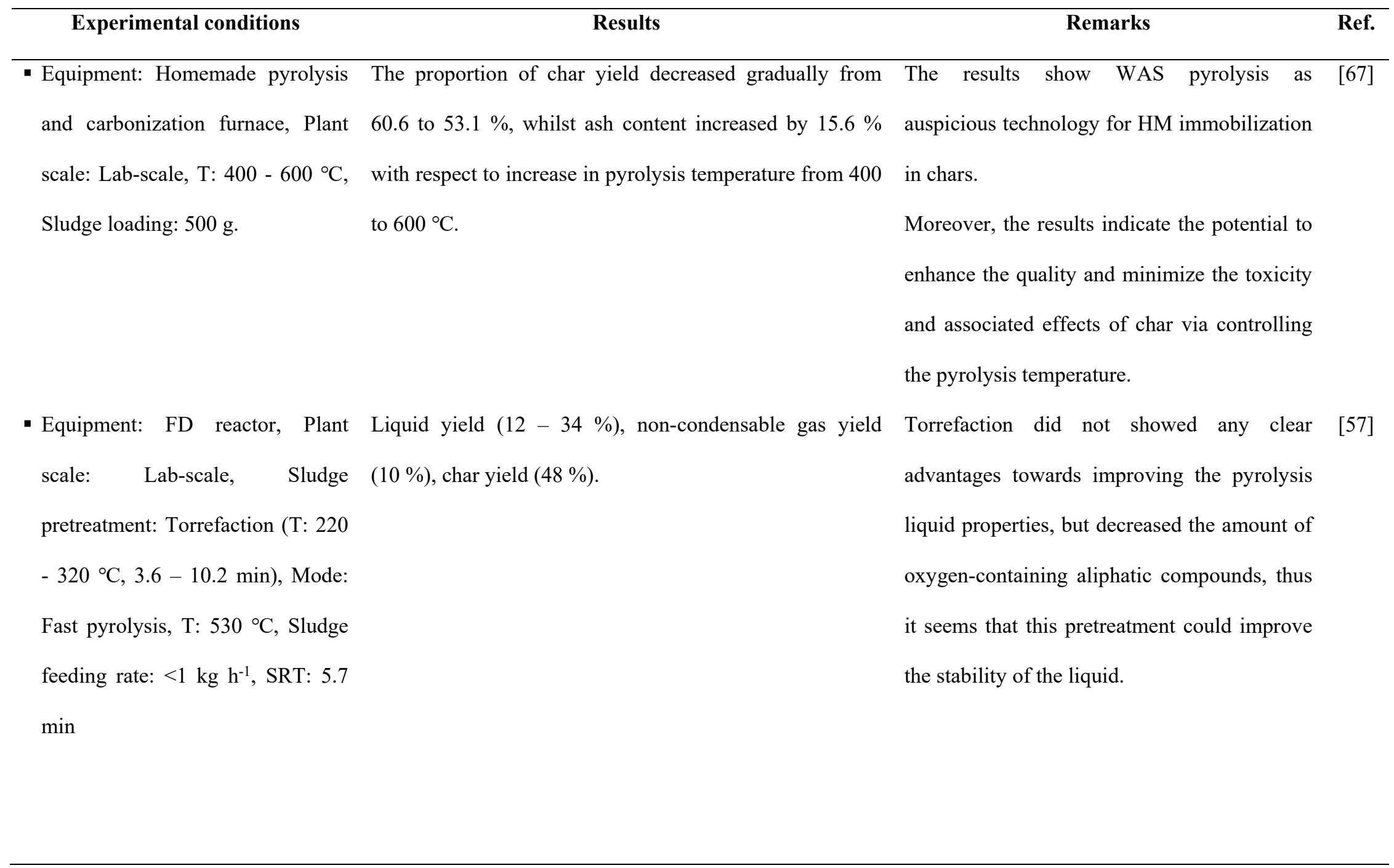




\begin{tabular}{|c|c|c|c|}
\hline Experimental conditions & Results & Remarks & Ref. \\
\hline $\begin{array}{l}\text { Equipment: continuous screw- } \\
\text { feeding reactor, Plant scale: Lab- } \\
\text { scale, T: } 500-800{ }^{\circ} \mathrm{C} \text {, Sludge } \\
\text { feeding rate: } 4.35-100 \mathrm{~g} \mathrm{~min}{ }^{-1} \text {, } \\
\text { RT: } 6-46 \mathrm{~min}\end{array}$ & $\begin{array}{l}\text { HMs in char and bio-oil }\left(\mathrm{mg} \mathrm{kg}^{-1} \text {, presented as Char/bio- }\right. \\
\text { oil): } \mathrm{Cu}(1500 / 129), \mathrm{Zn}(2996 / 38), \mathrm{Mn}(2388 / 33), \mathrm{Cr} \\
(680 / 10), \mathrm{Ni}(337 / 5), \mathrm{Pb}(134 / 4), \mathrm{Cd}(2 / 0) \text {. } \\
\text { Bio-oil yield (16.69\%), gas yield (16.49\%) and char } \\
\text { yield (65.2\%) }\end{array}$ & $\begin{array}{l}\text { The maximum bio-oil yield was obtained at } \\
700{ }^{\circ} \mathrm{C} \text { and SRT of } 23 \text { min. } \\
\text { The increase in temperature and SRT } \\
\text { decreased the char yields. } \\
\text { A great proportion of HMs retained in the } \\
\text { chars. }\end{array}$ & [56] \\
\hline $\begin{array}{l}\text { Equipment: microwave (MW) } \\
\text { oven, Plant scale: Lab-scale, MW } \\
\text { power: } 900 \text { Watt at } 2450 \mathrm{MHz} \\
\text { frequency, T: } 400-800{ }^{\circ} \mathrm{C} \text {, Sludge } \\
\text { loading: } 200 \mathrm{~g} \text {, Holding time: } 30 \\
\text { min }\end{array}$ & $\begin{array}{l}\text { Bio-oil yield (14-20 wt. \%), gas yield (15-29 wt. \%) and } \\
\text { char yield (57-69 wt.\%). The heating value of bio-oil } \\
\text { varied from } 8700-9200 \mathrm{kcal} \mathrm{kg}^{-1} \text {. Maximum energy } \\
\text { recovery of } 54 \% \text { at } 600{ }^{\circ} \mathrm{C} \text {. }\end{array}$ & $\begin{array}{l}\text { The elevated temperature decreases the yield } \\
\text { of bio-oil and chars and increases the gaseous } \\
\text { products. } \\
\text { MW assisted pyrolysis of wet sludge is a } \\
\text { promising approach for enabling pyrolysis oil } \\
\text { as fuel for various applications. }\end{array}$ & [59] \\
\hline
\end{tabular}




\subsection{Sludge gasification}

Gasification converts dried WAS into combustable gases known as syngas (mainly composed of $\mathrm{H}_{2}, \mathrm{CO}, \mathrm{CO}_{2}$ and $\mathrm{CH}_{4}$ ) under partical oxidation at elevated temperatures of $700-1000{ }^{\circ} \mathrm{C}$ [72]. Gasification reduces the volume and fixes the HMs in the solid residues [73]. Calorific value of syngas varies from 4 to $6 \mathrm{MJ} \mathrm{Nm}^{-3}$ and is mainly appropriate as a fuel for heating, steam trubine and gas engines etc., [74, 75]. WAS gasification mechanism includes four stages: (i) drying, (ii) pyrolysis or devolatization, (iii) combustion, and (iv) char gasification or reduction. Major reactions occurring during gasification are shown (Eqns. $3-11)[76,77]$.

Oxidation zone reactions:

$$
\begin{array}{ll}
\mathrm{C}+\mathrm{O}_{2} \rightarrow \mathrm{CO}_{2} & -4.6 \mathrm{~kJ} \mathrm{~mol}^{-1} \\
2 \mathrm{C}+\mathrm{O}_{2} \rightarrow 2 \mathrm{CO} & -123 \mathrm{~kJ} \mathrm{~mol}^{-1}
\end{array}
$$

Reduction zone reactions:

$$
\begin{array}{lc}
\mathrm{C}+\mathrm{CO}_{2} \rightarrow 2 \mathrm{CO} & 162 \mathrm{~kJ} \mathrm{~mol}^{-1} \\
\mathrm{C}+\mathrm{H}_{2} \mathrm{O} \rightarrow \mathrm{CO}+\mathrm{H}_{2} & 119 \mathrm{~kJ} \mathrm{~mol}^{-1} \\
\mathrm{C}+2 \mathrm{H}_{2} \rightarrow \mathrm{CH}_{4} & -87 \mathrm{~kJ} \mathrm{~mol}^{-1} \\
\mathrm{CO}+\mathrm{H}_{2} \mathrm{O} \rightarrow \mathrm{CO}_{2}+\mathrm{H}_{2} & -42 \mathrm{~kJ} \mathrm{~mol}^{-1}
\end{array}
$$

Reforming reaction occurs between hydrocarbons and steam (water vapor), which results in rich $\mathrm{H}_{2} / \mathrm{CO}$ mixture in gaseous products (Eqn. 9) whereas the hydrogen is further enhanced by water-gas shift (WGS) reaction (Eqn. 8) [78].

$$
\mathrm{CH}_{\mathrm{x}} \mathrm{O}_{\mathrm{y}}+(1-\mathrm{y}) \mathrm{H}_{2} \mathrm{O} \rightarrow \mathrm{CO}+(1-\mathrm{y}+\mathrm{x} / 2) \mathrm{H}_{2}
$$


The end-products of WAS gasification depend on its properties (such as moisture, $\mathrm{VM}$, ash, and thermal conductivity) and experimental conditions (such as temperature, HR, and feeding ratio) [79].

Table 4 shows experimental conditions and results corresponding to sludge air gasification [72, 80, 81], steam sludge gasification [72, 81, 82] and supercritical sludge gasification [83] reported in literature. These studies have shown considerable results for WAS gasification for producing hydrogen-rich syngas. However, implementation of WAS gasification confronts several challenges. For instance, higher moisture content of approximatley 80 wt. \% and lower heating value (LHV) of WAS are the major challenges, which results in lower gasification efficiency (GE) [84]. Whereas the dewatering process is energy-intensive (i.e. kilogram of $\mathrm{H}_{2} \mathrm{O}$ requires about 2,260 $\mathrm{kJ}$ of unrecoverable energy [74]) and thus, overall cost of WAS disposal becomes considerably higher. Moreover, high tar production from WAS gasification is also another main obstacle which requires additional treatment because it can probably hinder the gasifier operation through blocking the tubing or fouling the downstream apparatus [85]. The tar removal can be accomplished through two attempts: i) the 'primary method,' where tar treatment is performed inside the gasifier by considering various parameters (i.e., gasifier design, temperature, gasifying agent and catalysts), and ii) the 'secondary method,' where tar is removed from gaseous products by means of installing equipment after the gasifier [85]. The primary method has been proven more economically appealing than the secondary one, because it avoids high costs of installing additional technology such as gas scrubbers [86]. Choi et al. [80] (Table 4), studied the effect of ER and activated carbon (AC) to sludge ratio on tar production. With increasing ER from 0.22 to 0.5 , tar content, $\mathrm{H}_{2}$ yield, 
and HHV of producer gas were significantly decreased from 296 to $76 \mathrm{mg} \mathrm{Nm}^{3}, 28.1$ to $24.4 \mathrm{vol} \%$, and 6.25 to $5.27 \mathrm{MJ} \mathrm{Nm}^{3}$, respectively. This trend has also been widely reported in literature [85, 87]. Similarly, Roche et al. [72] (Table 4), investigated the effect of throughput (TR), the gasifying agent, and the dolomite catalyst on tar production and gas composition. The results showed that the increasing throughput reduced the $\mathrm{H}_{2}$ production and greatly increased the tar production. On the other hand, air plus steam, mainly in the presence of dolomite, improved the $\mathrm{H}_{2}$ production by $20-30 \%$, reaching tar removal efficiency of $\sim 71 \%$. Typical design of gasifier is also an alternative approach at primary tar removal. A recent study conducted by Molino et al. [88] highlighted an effective operation of the FD gasifier in biomass gasification, emphasizing special characteristics of FD gasifier (i.e. high mixing potential and a high tar conversion), particularly in presence of catalysts. Currently, numerous trials using the novel type or modified gasifiers have been used for tar reduction inside the gasifiers. Choi et al. [80, 89] (Table 4), conducted the sludge gasification with a three-stage gasifier (i.e. auger reactor, FD reactor, and tar-cracking reactor connected in sequence) and reported the least tar quantities of 22 and $27 \mathrm{mg} \mathrm{Nm}^{3}$ in producer gas, respectively. Another exclusive gasifier is that in which the catalytic filter components were integrated into the freeboard of the FD steam gasifier to enable the efficient tar and removal of trace elements (TEs) [90]. Moreover, Lurgi-Ruhrgas and the ChemChar waste gasification processes are considered as advanced technologies for sludge gasification, because they manage to achieve significant retaining of metals in the char matrix and high conversion of carbonaceous char residues from WAS into combustible gas [4]. 
On the other hand, WAS co-gasification with other carbonaceous materials entitles various benefits which advocate its utilization as a feedstock for gasification. Currently, WAS and woody biomass co-gasification have been extensively studied [73, 91-95]. The high VM, low ash and moisture content (in particular), are some of the major attributes of woody biomass that makes it an appropriate to be blended with moist WAS for gasification.

Peng et al. [73] investigated the co-gasification of wet WAS (76 \% dry basis moisture content) and woody biomass ( $8.6 \%$ dry basis moisture content) in a lab-scale fixed bed gasifier. The effects of different sludge mixing ratios $(0 \%, 30 \%, 50 \%, 70 \%$ and $100 \%$ in the test) and reactor temperatures (700 to $\left.900{ }^{\circ} \mathrm{C}\right)$ were assessed on product distribution and gasification performance. The results indicated that the sludge moisture participated in the gasification with char. The addition of woody biomass to WAS compensated the moisture content and improved the VM content in the blends. An optimum $\mathrm{H}_{2}$ and $\mathrm{CO}$ yield of $35.8 \%$ and $28 \%$ were obtained at a WAS ratio of $50 \%$ and temperature of $800{ }^{\circ} \mathrm{C}$. The LHV and carbon conversion efficiency (CCE) varied from 11.89 to $12.72 \mathrm{MJ} \mathrm{Nm}^{-3}$ and 57.86 to $72.21 \%$, respectively.

Ong et al. [94] co-gasified woody biomass with WAS in a fixed-bed downdraft gasifier. The effects of different WAS ratios $(0-33$ wt. \%) and operating temperature $\left(700-1000{ }^{\circ} \mathrm{C}\right)$ on the product distribution were studied. The results indicated that 20 wt. \% of WAS ratio in the feedstock was successfully gasified to generate gaseous products comprising of $>30$ vol. $\%$ of syngas $\left(\mathrm{H}_{2}\right.$ and $\left.\mathrm{CO}\right)$ with an average LHV of 4.5 $\mathrm{MJ} \mathrm{Nm}^{-3}$. Further increase in the WAS ratio to $33 \mathrm{wt}$ \% resulted in gasifier blockage due to the ash agglomeration. 
Furthermore, Seggiani et al. [93] co-gasified dehydrated WAS (20\% w/w moisture content) blended with woody biomass in a pilot-scale updraft fixed-bed gasifier operating at the atmospheric pressure. Authors found it viable to co-gasify WAS with woody biomass. However, at high content of WAS $(70 \% \mathrm{w} / \mathrm{w})$, slagging and extreme residue development in the oxidation zone could occur due to high ash content and low ash fusion temperatures of WAS, which makes the whole process unstable. It was found that increase in the ER leads to higher gas yields and cold gas efficiencies (CGE).

Similarly, Lee et al. [95] determined the optimum process parameters and their influence on gas composition via co-gasification of WAS blended with woody biomass in a FD gasifier. The WAS and woody biomass were mixed at different ratios of $50-100$ wt. $\%$, respectively. The temperature was varied from 600 to $900{ }^{\circ} \mathrm{C}$. By adding the wood, $\mathrm{H}_{2}$ and $\mathrm{CO}$ increased from 4 to $7 \%$ and 11.5 to $19 \%$ at WAS mixing ratios from 100 to $50 \%$ and 100 to $60 \%$, respectively. Temperature also supported gaseous products at elevated temperatures. 
Table 4. Summary of key information of WAS Gasification.

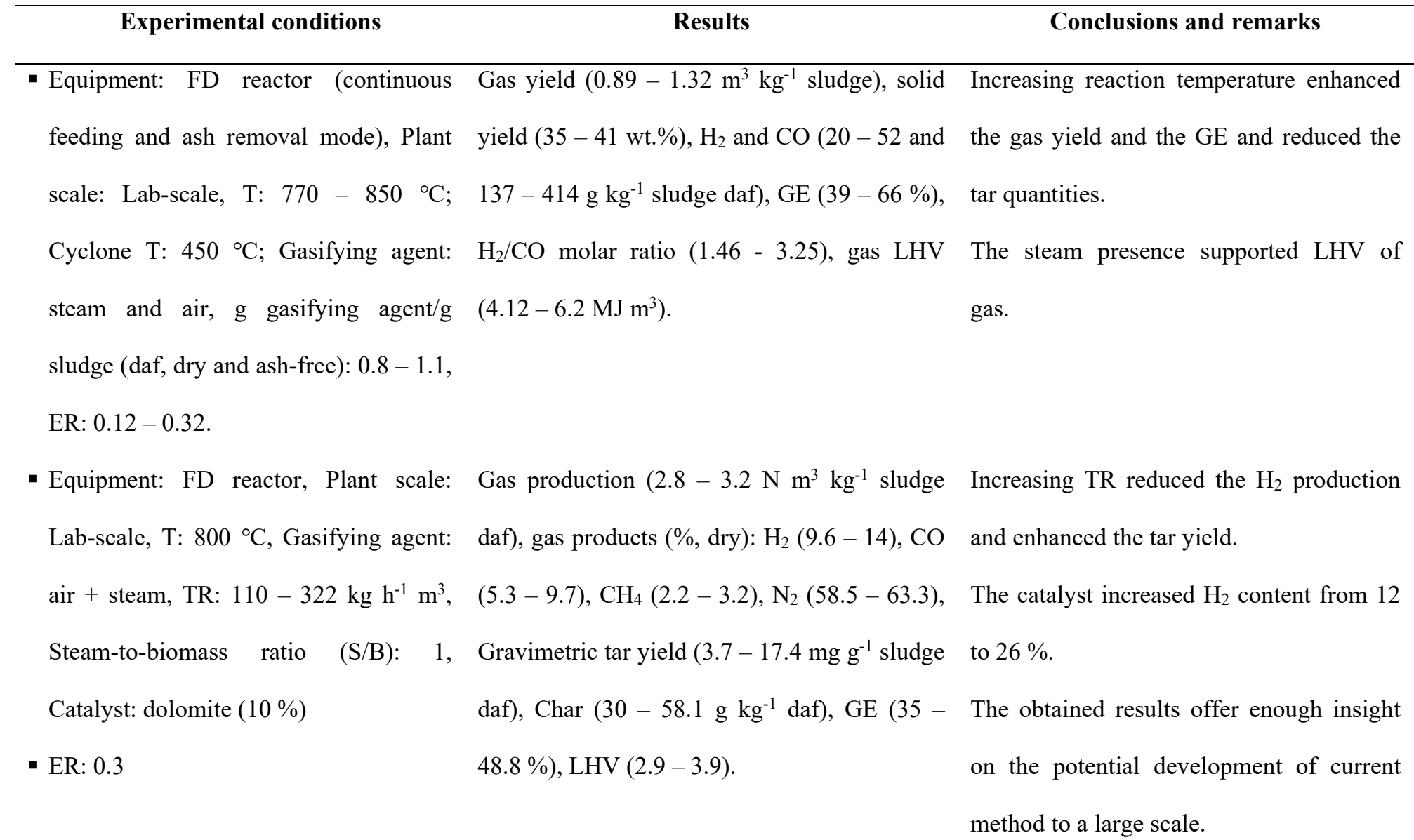




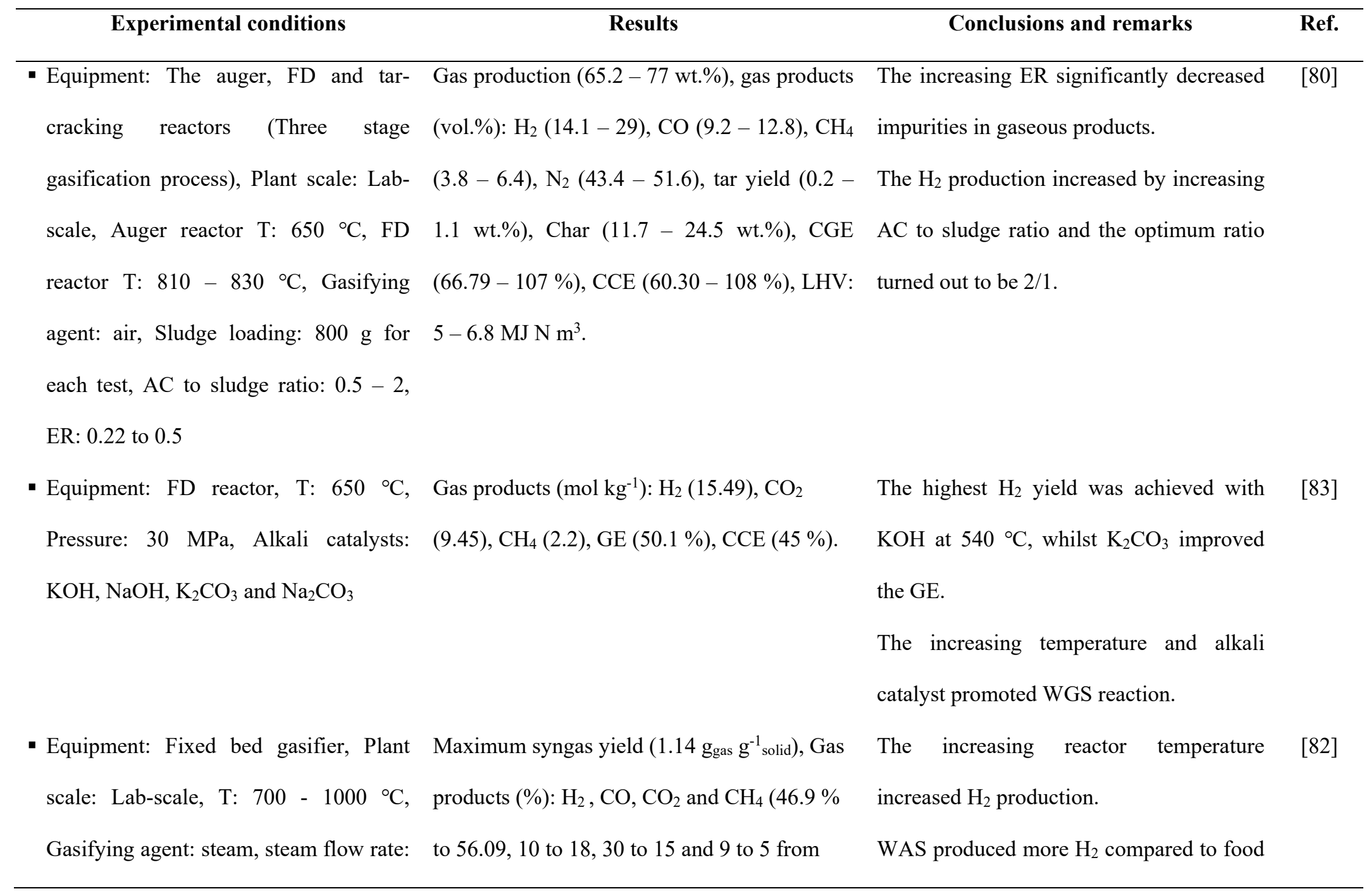


$0.3 \mathrm{~g} \mathrm{~min}^{-1}$, Sludge loading: $35 \mathrm{~g}$ for 700 to $1000^{\circ} \mathrm{C}$ ).

each test

[96] and paper [97] waste under same

experimental conditions.

Steam gasification of WAS yielded about

three times higher $\mathrm{H}_{2}$ than that of air

gasification [98]. 


\subsection{Integration of microbial fuel cells with WAS treatment}

Bioelectrochemical systems (BES), such as microbial fuel cells (MFCs) are a fascinating technology that biologically converts OM into electricity $[99,100]$. MFCs are advantageous on account of their ability to directly convert OMs into electricity and their efficient operation under ambient temperature, normal pressure and neutral $\mathrm{pH}$. These characteristics distinguish them from all other existing bioenergy approaches. In a MFC, electrons produced through bacteria from the OM are switched to the anode and flow to the cathode connected via a conductive substance comprising a resistor [101]. In the cathode, terminal electron acceptors (e.g., oxygen) consume the electrons to complete the electrochemical reaction. Recently, various studies have reported the successful application of MFC technology for producing bioelectricity from organic wastes (e.g., WAS) [102-104]. MFCs significantly decrease the adverse environmental impacts associated with conventional WAS treatment (e.g., incineration and landfill) [105]. Dentel et al. [106] first demonstrated the direct generation of electricity from sludge via MFC. They used anaerobically digested sludge and achieved a maximum voltage of 517 $\mathrm{mV}$ [106]. Thenceforth, the concern of addressing an enhanced power generation from WAS has become the key research direction $[99,102,103,107,108]$, and the power output densities increased from 2004 to $2017\left(0.1\right.$ to $\left.227 \mathrm{~W} / \mathrm{m}^{3}\right)$ [108]. In addition to power generation, sludge digestion is also of utmost significance to make MFC technology competent. Ghadge et al. [109] have reported the simultaneous sludge degradation of $81 \%$ and power generation $\left(8.7 \mathrm{~W} \mathrm{~m}^{3}\right)$ in MFC with sodium hypochlorite as catholyte within short RT of 8 days. Moreover, as compared to other fermentable materials (e.g., glucose, acetic acid and lactic acid) typically exploited in MFCs, WAS 
composition is complex, slowly biodegradable, and the persistent biomaterials/organics are challenging to be consumed efficiently [110]. Thus, to make these refractory organics more susceptible to effective microbial degradation pretreatment of WAS is absolutely imperative [111]. Today, many pretreatment methods such as alkaline pretreatment [112114], ultrasonic pretreatment [103, 111, 113], aerobic digestion [107], thermal pretreatment [107], microwave digestion [115], ozonation [115] have been explored to enhance the electricity generation via WAS in MFCs. Jiang et al. $[103,111,113]$ investigated the ultrasonic and alkaline pretreatments. Both methods accelerated the OM dissolution leading to remarkable total COD removal rate. Xiao et al. [107] and Yuan et al. [116] studied the base and heat pretreatments as an effective alternatives to accelerate the hydrolysis, and thereby increasing electricity production. However, recent findings have shown the possibility of destruction of the original microbial consortia via base and heat pretreatments, indicating that inoculation would be essential in BES [107]. More recently, $\mathrm{Oh}$ et al. [117] evaluated the influence of ultrasonic and heat/alkaline pretreatments with varied sources of sludge (such as primary sludge, WAS and AD sludge) for electricity production in MFCs. Although the aforementioned pretreatments are efficient in liquefying WAS and promoting overall system performance, they also increase the operational cost of MFCs. Thus, more cost-effective approaches as recently adopted by Suor et al. [99] and Cia et al. [118] should be further researched to increase electricity generation from WAS via MFCs. 


\section{COMPARATIVE STUDY OF THE LEADING TECHNOLOGIES FOR SLUDGE DISPOSAL}

The comparison among well-known technologies for WAS is depicted in Table 5. On the account of stringent flue gas emission requirements, WAS incinerators require advanced emission control systems [70]. Additionally, WAS co-firing with coal and/or biomass appears a favourable and encouraging option. The pyrolysis of WAS is a more complex technology when compared with incineration. However, compared to incineration, pyrolysis entitles potential benefits such as zero waste method, the lower costs, less environmental impact and much lower dependency on ever diminishing fossil fuel reserves [70].

Moreover, these versatile benefits endow WAS pyrolysis with adequate capacities to be stepped up for commercial applications in the near future. Nonetheless, enhancement of energy conversion efficiency is the major consideration and an area of concern for WAS pyrolysis. Conversion technologies like WAS pyrolysis and gasification are still in embryonic stages. Several of the claims such as pollution-free and economic viability for these technologies are based on laboratory and pilot scale demonstration projects. The real problem with these approaches is that the plants fail to meet the increasingly stringent air quality and emissions standards when scale up to real world applications or outside of the laboratory $[70,119,120]$. In addition, some other limitations on WAS technological advancement are as follows:

- Improper matches among the risk bearing capabilities of suppliers, clients, and investors. Generally, they are not able or reluctant to realize/accept any levels of 
the probable risks associated with a project if the technology applied is unguaranteed or unproven.

- The obstacles to secure safe investment for technologies with restrict operating experience and/or without any proved track record.

- For WAS treatment and disposal, low gate fees are enumerated as one of the major inhibitors for all types of waste management projects and the inhibition is mostly linked to the utilization of capital intensive plant and equipment, indeed.

- Considering unreal expenses of scarce resources and other benefits as the priority rather than actual effort and focus on developments that might result in real advantages. 
Table 5. Comparative analysis of leading sludge treatment technologies [4, 14, 23, 70, 104, 121-125].

\begin{tabular}{|c|c|c|c|}
\hline Technology & Factors & Recognized benefits & Limitations \\
\hline \multirow{3}{*}{ Incineration } & Technological & $\begin{array}{l}\text { 1) Well-established and reliable } \\
\text { 2) About } 90 \% \text { WAS volume reduction } \\
\text { 3) Almost complete destruction of toxic organic components } \\
\text { and pathogens } \\
\text { 4) Heat recovery to power the steam turbine and WAS } \\
\text { drying) }\end{array}$ & $\begin{array}{l}\text { 1) Dewatering of the sludge is required (41-65 wt. \% } \\
\text { content of dry material) } \\
\text { 2) Incineration can be energy deficient } \\
\text { 3) Far from Zero Waste method }\end{array}$ \\
\hline & $\begin{array}{l}\text { Social- } \\
\text { Environmental }\end{array}$ & $\begin{array}{l}\text { 1) Low GHG emissions compared to open burning } \\
\text { 2) Co-combustion with other conventional fuels such as coal } \\
\text { can reduce GHG emissions and public acceptability } \\
\text { thereof }\end{array}$ & $\begin{array}{l}\text { 1) Strong Public's opposition } \\
\text { 2) Mono-incineration: } 232.2 \mathrm{~kg} \mathrm{CO} 2 \text { eq./t sludge } \\
\text { 3) Co-incineration with municipal solid waste } \\
\text { (MSW): (-15.4 kg CO} 2 \text { eq./t sludge) } \\
\text { 4) } \mathrm{NOx} \text { and } \mathrm{SO}_{2} \text { emissions, slag, TEs, fly ash and } \\
\text { ash disposal }\end{array}$ \\
\hline & Economic & $\begin{array}{l}\text { 1) Energy savings } \\
\text { 2) Existing infrastructure of energy kilns } \\
\text { 3) Co-firing with other conventional fuels }\end{array}$ & $\begin{array}{l}\text { 1) Strict and expensive emission control } \\
\text { 2) High cost of the flue gas cleaning and ash disposa } \\
\text { problems (HMs etc.) }\end{array}$ \\
\hline
\end{tabular}




\begin{tabular}{|c|c|c|c|}
\hline Technology & Factors & Recognized benefits & Limitations \\
\hline \multirow{3}{*}{ Pyrolysis } & Technological & $\begin{array}{l}\text { 1) It converts both raw and digested WAS into useful } \\
\text { bioenergy. } \\
\text { 2) Non-burning and zero waste process } \\
\text { 3) Bio-oil: used to produce various chemicals and even as a } \\
\text { fuel } \\
\text { 4) Biochar (HHV of WAS is } \sim 5 \mathrm{MJ} \mathrm{kg}^{-1} \text { ) as a byproduct } \\
\text { (holds potential for carbon sequestration and soil } \\
\text { conditioning) }\end{array}$ & $\begin{array}{l}\text { 1) Complex when compared with incineration } \\
\text { 2) Dewatering requirements limits the WAS } \\
\text { pyrolysis applications } \\
\text { 3) Products have not very well established markets } \\
\text { 4) Pyrolysis gas needs less treatment to meet } \\
\text { emission limits than incineration } \\
\text { 5) Limited technological acceptance by the low } \\
\text { economic value of the produced oil }\end{array}$ \\
\hline & $\begin{array}{l}\text { Socio- } \\
\text { Environmental }\end{array}$ & $\begin{array}{l}\text { 1) Lowest GHG emissions than incineration due to the } \\
\text { lower temperatures and oxygen absence } \\
\text { 2) Lower temperatures are also responsible for the HMs } \\
\text { absence in the pyrolysis gas } \\
\text { 3) Turns a waste into a valuable raw material }\end{array}$ & $\begin{array}{l}\text { 1) Air pollution } \\
\text { 2) HMs remain trapped in the resulting char, those } \\
\text { require costly treatments, without which their } \\
\text { landfilling is not possible due to legal constrains }\end{array}$ \\
\hline & Economic & $\begin{array}{l}\text { 1) Viability is proven only in large scale plants }(>20,000 \\
\text { tons year-1) } \\
\text { 2) Sustainable development and green entrepreneurship }\end{array}$ & $\begin{array}{l}\text { 1) High investment cost } \\
\text { 2) Unstable economic environment }\end{array}$ \\
\hline
\end{tabular}




\begin{tabular}{|c|c|c|c|}
\hline Technology & Factors & Recognized benefits & Limitations \\
\hline \multirow[t]{3}{*}{ Gasification } & Technological & $\begin{array}{l}\text { 1) Turn various types of waste into useful energy } \\
\text { 2) Potential of co-feeding with biomass } \\
\text { 3) High energy efficiency } \\
\text { 4) Marketable products: WAS conversion to a combustible } \\
\text { gas (i.e. syngas), which significantly contributes to } \\
\text { produce methanol. } \\
\text { 5) Char or slag, oils and water as byproduct } \\
\text { 6) Avoids problems such as supplementary fuel, SOx and } \\
\text { 7) Energy self-sustaining }\end{array}$ & $\begin{array}{l}\text { 1) WAS water content required }(<10 \% \text { dry solids } \\
\text { (DS) content) } \\
\text { 2) WAS dewatering and drying is essential } \\
\text { 3) Gas cleaning for syngas applications } \\
\text { 4) HHV of WAS syngas reaches } \sim 4 \mathrm{MJ} \mathrm{m}^{-3} \text {, which is } \\
\text { suitable for electricity/heat }\end{array}$ \\
\hline & $\begin{array}{l}\text { Socio- } \\
\text { Environmental }\end{array}$ & $\begin{array}{l}\text { 1) Lower environmental impacts } \\
\text { 2) Turn a waste into energy }\end{array}$ & $\begin{array}{l}\text { 1) Heavy organic pollutant compounds in the } \\
\text { exhaust stream }\end{array}$ \\
\hline & Economic & $\begin{array}{l}\text { 1) Economies of scale and automation favor large scale } \\
\text { operations } \\
\text { 2) Green Entrepreneurship } \\
\text { 3) Sustainable development }\end{array}$ & 1) High investment and operation cost \\
\hline
\end{tabular}




\begin{tabular}{|c|c|c|c|}
\hline Technology & Factors & Recognized benefits & Limitations \\
\hline \multirow{3}{*}{$\begin{array}{l}\text { Anaerobic } \\
\text { digestion }\end{array}$} & Technological & $\begin{array}{l}\text { 1) Accepts organic feedstocks with high moisture content } \\
(80-90 \%) \text {, thus suitable for WAS. } \\
\text { 2) Methane-rich and high calorific value biogas } \\
\text { 3) Combined heat and power plants. }\end{array}$ & $\begin{array}{l}\text { 1) Lengthy reaction steps } \\
\text { 2) Low conversion efficiency by microbe and/or } \\
\text { enzyme } \\
\text { 3) The HMs and Persistent organic pollutants (POPs) } \\
\text { contained in WAS cannot be alleviated via AD }\end{array}$ \\
\hline & $\begin{array}{l}\text { Socio- } \\
\text { Environmental }\end{array}$ & $\begin{array}{l}\text { 1) Significant reduction in carbon emissions } \\
\text { 2) Creates jobs and increases skilled labor force } \\
\text { 3) Replaces chemical fertilizer with organic fertilizer for } \\
\text { arable land } \\
\text { 4) Decreases use of firewood, helping to combat } \\
\text { deforestation }\end{array}$ & $\begin{array}{l}\text { 1) Digestate resulted from } \mathrm{AD} \text { would have impacts } \\
\text { on the public health and environment if not treated } \\
\text { properly. }\end{array}$ \\
\hline & Economic & $\begin{array}{l}\text { 1) Digestate is energy profitable due to its organic matter } \\
\text { 2) Reduces transport and disposal costs } \\
\text { 3) Cost-effective fertilizer } \\
\text { 4) Green Entrepreneurship } \\
\text { 5) Sustainable development }\end{array}$ & 1) High capital and maintenance costs \\
\hline
\end{tabular}




\begin{tabular}{|c|c|c|c|}
\hline Technology & Factors & Recognized benefits & Limitations \\
\hline \multirow[t]{3}{*}{$\begin{array}{l}\text { WAS- } \\
\text { microbial } \\
\text { fuel cell }\end{array}$} & Technological & $\begin{array}{l}\text { 1) It is a clean technology (no combustion) } \\
\text { 2) Direct conversion of a great variety of organics into } \\
\text { electricity } \\
\text { 3) Efficient operation under ambient temperature, normal } \\
\text { pressure and neutral pH. } \\
\text { 4) Sludge stabilization and volume reduction } \\
\text { 5) Noise free operation }\end{array}$ & $\begin{array}{l}\text { 1) Low power output. } \\
\text { 2) Pretreatment requirement due to complex } \\
\text { structure of WAS } \\
\text { 3) The scale-up is still a big challenge } \\
\text { 4) Biological fouling } \\
\text { 5) In some cases, (i.e. phototrophic MFCs) artificia } \\
\text { illumination is required } \\
\text { 6) The lack of electrolytes buffer capacity drastically } \\
\text { impediment scaling up of MFCs for WWT }\end{array}$ \\
\hline & $\begin{array}{l}\text { Socio- } \\
\text { Environmental }\end{array}$ & $\begin{array}{l}\text { 1) Considerable reduction of environmental impacts } \\
\text { associated with WAS treatment. } \\
\text { 2) Bioenergy in the form of electricity. } \\
\text { 3) It diminishes the competition with food production as is } \\
\text { the concern with conventional biofuels. }\end{array}$ & \\
\hline & Economic & $\begin{array}{l}\text { 1) Energy saving. } \\
\text { 2) Reduced maintenance cost since not moving parts. }\end{array}$ & $\begin{array}{l}\text { 1) High operational (i.e. pretreatment) and materia } \\
\text { costs (i.e. membrane materials, Pt catalyst and }\end{array}$ \\
\hline
\end{tabular}




\begin{tabular}{l|l|l|l}
\hline & 3) Sustainable development. & $\begin{array}{l}\text { bipolar plates etc.). } \\
\text { 2) Additional costs for artificial illumination. }\end{array}$ \\
\hline
\end{tabular}


$\mathrm{AD}$ is the most prevalent sludge disposal route as it is not affected by high water content of the sludge. However, it suffers from long processing time, improper removal of the $\mathrm{OM}$ and low efficiency. Incineration has high efficiency and can be employed to generate power. However, flue gases require expensive treatment unlike AD before they are vented out to the atmosphere. Other thermal treatments such as gasification and pyrolysis have important benefits as they generate syngas and bio-oil, respectively, which can be used for diverse applications, but they suffer from low efficiency and high costs of WAS pretreatment to reduce moisture content. Developments in the technologies such as AD coupled with pyrolysis, co-combustion and co-incineration are needed to diminish the energy penalty and improve the progress economics. This will in turn aid in the scale up of pilot plant studies to commercial level applications.

\section{CO-PRODUCTION OF BIOREFINERY PRODUCTS FROM SEWAGE}

\section{SLUDGE}

\subsection{Enzymes}

Three major biochemical families (carbohydrates, proteins and lipids) of WAS represent approximately $80 \%$ of the OM [3]. Thus, the recovery of various enzymes (e.g. lipases, dehydrogenase, glycosidase, peroxidase, and aminopeptidases) from WAS is essential on account of their high value. Nabarlatz et al. [126] studied various enzyme extraction methods. The obtained results proved ultrasonication alone or supported with additives as an effective approach for enzyme recovery methods at the operating conditions listed in Table 6. They also suggested that enzymes help to enhance the bio-digestibility of OMs towards higher biogas production during $\mathrm{AD}$ and so forth [126]. Likewise, according to 
Guanghui et al. [127] (Table 6), using ultrasonication supported by ethylenediaminetetraacetic acid recovered various enzymes from WAS. The method demonstrated an effective recovery of the hydrolytic enzymes (e.g. lipase and protease).

More recently, Ni et al. [53] (Table 6), utilized WAS to extract the hydrolytic enzymes. According to observations, the produced enzymes appear to be an appropriate compound enzyme for feed.

Generally, enzymes are biological catalysts that upsurge the rate of chemical reactions and are employed commercially for various industrial applications such as pharmaceutical, food, diagnostics, cosmetics, detergent and fine chemical industries. With regard to their wide commercial significance, reliable and economical supply of these enzymes is a key endeavor on account of the fact that $30-40 \%$ of the production costs in aforementioned industries attribute to the cost of preparing culture medium [128]. Therefore, WAS-derived enzymes could potentially lessen the industrial processing time and cost. Therefore, holistic research is required to optimize the enzyme recovery along with techno-economical assessment of the processes. The enzymes produced are appropriate for certain industrial applications (e.g., as additives for detergents or biocatalysts in esterification reactions); however, such applications demand high purity and specific enzymatic activity, and therefore further purification and concentration procedures are usually required.

\subsection{Bio-plastics}

The plastics are commonly derived from petrochemicals. However, the environmental and human health problems related to the application of conventional plastics 
(petrochemical derived plastics) have motivated researchers to develop the biodegradable alternative.

Besides, other polymers such as polyhydroxyalkanoates (PHAs), which exhibit properties comparable to petroleum based plastics, are a group of biodegradable polymers (linear polyesters) produced via microorganisms using carbon as a substrate [129]. Polybeta-hydroxybutyric acid and its co-polymer poly (3-hydroxybutyrate-co-hydroxyvalerate $[\mathrm{P}(3 \mathrm{HB}-\mathrm{co}-\mathrm{HV})])$ are very common PHAs [130].

Several microorganisms in WAS have the ability to accumulate PHAs (0.30 to 22.7 mg polymer g-sludge [131]); however, high production cost (i.e. $\sim$ USD $4-6 \mathrm{~kg}^{-1}$ compared to USD $0.6-0.9 \mathrm{~kg}^{-1}$ for conventional plastics) $[129,132]$ has limited their widespread uses. The current advances in bacterial fermentation and WAS use are likely to improve the yield and diminish the process costs of PHAs production [129, 132-135].

The excess carbon and limitation approach under 'feast and famine' conditions has been observed promising for the effective cultivation of PHA yielding organisms. In addition, Longo et al. successfully exploited nitorgen removal strategy to obtain higher yield of PHA during the PHA production step [136]. However, being aerobic, these processes are energy intensive (1 kg PHA production requires $\sim 39 \mathrm{MJ})$, when the aerobic accumulation step is used [137]. Table 6 presents the experimental approaches applied for the extraction of PHAs. Jiang et al. [138], Morgan-Sagastume et al. [139], and Pittamnn et al. [135] (Table 6) examined the potential for the enhancement of PHA producing communities and the PHA accumulation capacity of fermented sludge under varying experimental conditions. The obtained results demostrated the successful enrichment of PHA-storing communities by means of the fermented sludge as feedstock, 
albeit excessive nutrient loads did control the maximum level of PHA accumulation [139]. Morgan-Sagastume et al. [139] also scrutinized a novel concept for the operation of WWTP, where the variety of PHA accumulating organisms were successfully supplemented based on the conversion of the readily biodegradable COD from municipal wastewater without its pre-conversion to VFAs [140]. On the other hand, post-treatment was necessitated, especially for higher nurtient removal of the treated effluent [141].

Recently, a pilot-scale study conducted by Bengtsson et al. [140] demonstrated PHA accumulation potential integrated with biological nitrogen removal through predenitrification, nitrification and post-denitrification. The obtained PHA accumulation potential was comparable to what has been formerly reported by employing a completely aerobic 'feast and famine' process [141]. Therefore, based on above results, nitrogen removal could be assimilated into the enrichment process without diminishing the PHA accumulation potential. But, this is directly contrary to what has been reported in literature [142]. Moreover, Bengtsson et al. [140] also confirmed previously reported findings of high PHA accumulation using conventional domestic wastewater regardless of low to negligible concentrations of influent VFAs [141]. Alternatively, municipal WWT has been using streams with high VFAs resulting from fermentation of solids to produce enhanced biomass along with high PHA accumulation $[135,143,144]$, which has been reported as unnecessary [140]. Therefore, the conversion of highly concentrated VFA-media into only polymers seems to be a good choice rather than biomass and polymers. This will in turn lead to a higher overall PHA potential. Despite the clear technical potential of PHAs in sludge, it is not yet economically appealing [129, 145]. 
Therefore, to make sludge-derived PHAs more attractive in future, holistic research approach aiming to improve the yields through process integration, parametric optimization, and PHAs storage capacity, etc., are necessary. Such aspects will boost the confidence and effectiveness in the industrial fraternity about the economic and commercial viability of the technology.

\section{3 Bio-pesticides}

Currently, Bacillus thuringiensis (Bt) is by far the most effective bio-pesticide, which owns the ability to produce delta endotoxins ( $\delta$-endotoxin, known as cry and cyt toxins), being utilized widely in agronomy, forestry and public sector [3, 146]. Moreover, biopesticides are highly target specific compounds with zero toxic residues, and therefore have a much lesser impact on the environment compared to chemical pesticides. However, high cost associated with raw materials has impeded the commercial application of $B t$ to a great extent [147]. The conventional fermentation medium for $B t$ based bio-pesticides production carries a significant portion of $\sim 40-60 \%$ of the total production cost $[148,149]$. Therefore, it has become important to explore a new raw material considering some criteria which should include i) renewable in nature, ii) high yielding potential, iii) cost-effectiveness, and iv) year round availability for $B t$ production. With these, WAS appears to be highly nutritional and cost-effective medium for $B t$ production $[150,151]$, which will substantially reduce the $B t$ production cost and will contribute to sustainable WAS utilization and management. WAS based bio-pesticide production undergoes three steps namely, i) WAS fermentation, ii) harvesting and/or product recovery, and iii) product formulation. The use of sludge for Bt production has been widely studied as shown in Table 6 [147, 152, 153]. These studies have 
demonstrated that $B t$ based bio-pesticides production highly depends on fermentation conditions such as $\mathrm{pH}, \mathrm{C} / \mathrm{N}$ ratio, dissolved oxygen concentration, solids concentration and inoculum sludge type. Montiel et al. indicated that more than $50 \%$ of net savings can be achieved by substituting commercial medium for producing $B t$ with WAS (\$0.25-0.34 $\mathrm{L}^{-1}$ sludge medium vs $\$ 0.75 \mathrm{~L}^{-1}$ commercial medium) $[152,154]$. Attending a higher entomotoxicity (Tx) level could led to further decrease the Bt production cost [152]. Zhuang et al. [147] (Table 6), showed higher yields of Tx corresponding to different substrates (i.e. sludge + wheat and commercial medium) compared to sludge, indicating the reliance of $\mathrm{Tx}$ production efficiency on the type of medium. The lower $\mathrm{Tx}$ productivity in sludge sample could be attributed to the complex nature of sludge and thus less biodegradability. Vidyarthi et al. [155] indicated the availability of biodegradable OMs in the substrate was very crucial limiting factor for obtaining a high yield of $\mathrm{Tx}$ and $\delta$-endotoxin. Therefore, the suitable pretreatment to alter less biodegradable materials into more easily degradable ones is highly recommended $[156$, 157]. Ultrasonication as sludge pretreatment has been introduced as a potential approach to improve the sludge biodegradability [158]. However, recently, Fenton oxidation pretreatment was proven to be more effective for growth of sludge based $B t$ production compared to ultrasonication pretreatment, proposing that further research on $B t$ production using above pretreatment in large scale reactor are needed [153]. Zhuang et al. [147] also demonstrated the feasibility of producing $B t$ based bio-pesticides using WAS as raw materials under solid-state fermentation technology. The effect of $\mathrm{HMs}[\mathrm{Pb}(0-$ $\left.300 \mathrm{mg} \mathrm{L}^{-1}\right), \mathrm{Cu}\left(0-150 \mathrm{mg} \mathrm{L}^{-1}, \mathrm{Cd}\left(0-30 \mathrm{mg} \mathrm{L}^{-1}, \mathrm{Cr}\left(0-300 \mathrm{mg} \mathrm{L}^{-1}\right)\right]\right.$ on $\mathrm{Bt}$ production was examined. The highest $\mathrm{Bt}$ production corresponding to $\mathrm{Pb}, \mathrm{Cu}, \mathrm{Cd}$ and $\mathrm{Cr}$ 
was found to be $227,82,15$, and $263 \mathrm{mg} \mathrm{L}^{-1}$, respectively. The high contents of HMs had considerable negative influence on the growth, crystal formation and toxicity of $B t$. The extent of metal toxicity to $B t$ production caused $50 \%$ inhabitation in total cell (TC) biomass of $B t$. Among the examined metals, $B t$ exhibited the utmost tolerance against $\mathrm{Cr}$ (III), followed by $\mathrm{Pb}(\mathrm{II}), \mathrm{Cu}(\mathrm{II})$ and $\mathrm{Cd}(\mathrm{II})$.

Thus, sludge based Bt production followed by its use to forests and in particular, agro-crops for pest control appears to be entirely compatible with up-to-date sludge disposal practices (e.g. zero or minimal transportation cost). However, the aforementioned methods mostly suffer from low $B t$ productivity and complex nature of sludge. Therefore, further studies focusing on downstream processing (i.e., parametric optimization, process control, and product separation/purification) are required to enhance $B t$ production into the global pesticide market. This will also contribute to sustainable sludge utilization and management by developing the final $B t$ formulation, and consequently expand the repertoire of commercial Bt product types.

\subsection{Proteins}

The major organic constituents of WAS are polysaccharides, proteins and lipids [159, 160]. Noticeably, due to the higher portion of proteins ( $\sim 50 \%$ dry weight of bacterial cells), WAS has high potential to be used as a protein source $[3,161]$. On another side, protein is an essential component used in animal feed for supplying energy and nitrogen [160]. Thus, protein recovery from WAS offers various benefits over traditional protein recovery sources. For instance, destruction of microbes can result in increased dewaterability, and the protein removed WAS would take less volume and inhibit limited OMs. 
Many significant studies on protein extraction and analysis from WAS have been published [160-164], as listed in Table 6. Hwang et al. [163] disintegrated WAS $(5,330$ $\mathrm{mg} \mathrm{L}^{-1}$ ) for the intracellular protein recovery assisted by an alkali treatment coupled with ultra-sonication under the parametric conditions elucidated in Table 6. They reported protein extraction rate as high as $80 \%$ at an optimum $\mathrm{pH}$ of 3.3 , with comparable nutrimental composition as of commercial protein feeds and thus suitable as an animal feed supplement. Similarly, Jimenez et al. [161] (Table 6) investigated the efficiency of different colorimetric methods such as Lowry, modified Lowry, and the Bicinchonic Acid (BCA) to characterize the OM (e.g. protein, carbohydrates and lipids) contents of the WAS. The protein was found as a main component representing $50 \%$ of biochemical portion. 
Table 6. Summary of key information of WAS bio-refinery.

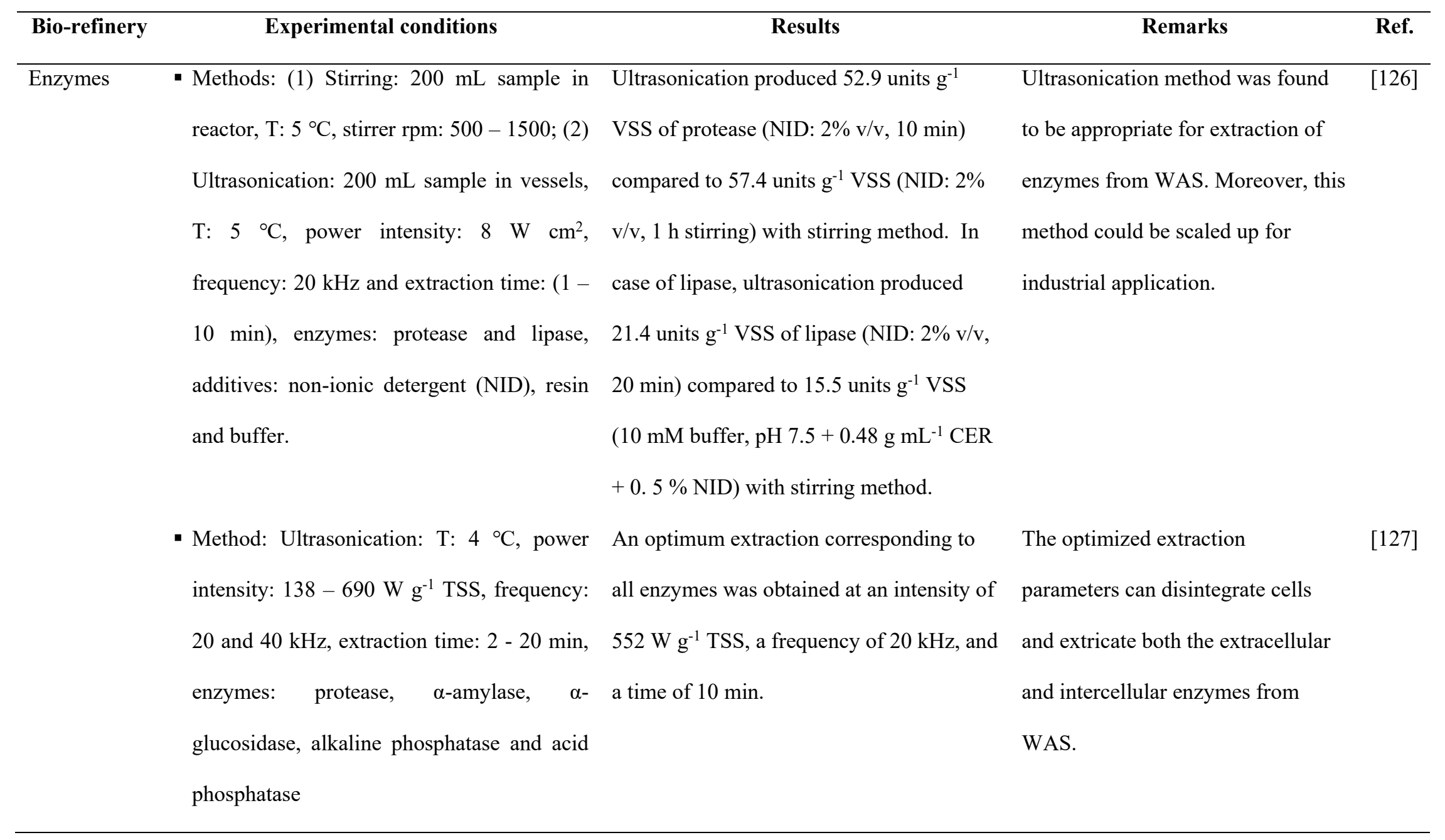




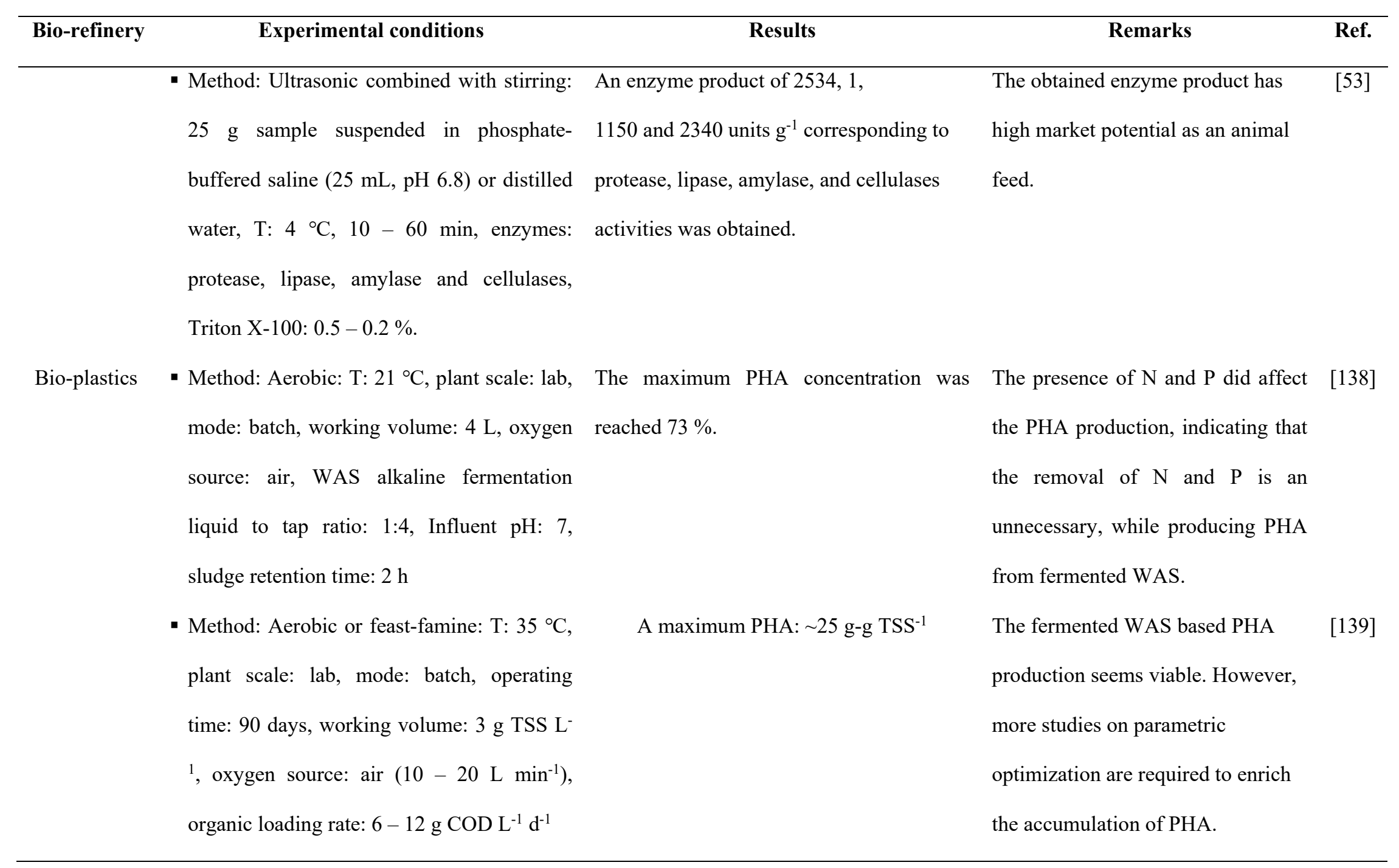




\begin{tabular}{|c|c|c|c|c|}
\hline Bio-refinery & Experimental conditions & Results & Remarks & Ref. \\
\hline \multirow{4}{*}{$\begin{array}{l}\text { Bio- } \\
\text { pesticides }\end{array}$} & $\begin{array}{l}\text { - Method: Aerobic: } \mathrm{T}: 15-30^{\circ} \mathrm{C} \text {, plant scale: } \\
\text { lab, mode: batch, rector operating time: } 90 \\
\text { days, substrate concentration (SC): } 1200 \text { - } \\
2000 \text { mgVFA L-1, pH: } 6-9 \text {, cycle time } \\
\text { (CT): } 24-72 \mathrm{~h} \text {. }\end{array}$ & $\begin{array}{l}\text { A highest PHA production of } 25.9 \% \\
\left(20{ }^{\circ} \mathrm{C}, 1200 \mathrm{mg}_{\mathrm{VFA}} \mathrm{L}^{-1}, \mathrm{pH} 7\right) \text { and } 28.4 \% \\
\text { cell dry weight }(24 \mathrm{~h}, \mathrm{pH} 8) \text { was achieved. }\end{array}$ & $\begin{array}{l}\text { The PHA production was highly } \\
\text { affected by temperature, } \mathrm{pH}, \mathrm{SC} \text { and } \\
\mathrm{CT} \text {. Lower } \mathrm{SC}, 20^{\circ} \mathrm{C} \text {, neutral } \mathrm{pH}- \\
\text { value and } 24 \mathrm{~h} \mathrm{CT} \text { were found best } \\
\text { for high production of PHA. }\end{array}$ & [135] \\
\hline & $\begin{array}{l}\text { - Method: Fermentation: STR bioreactor, } B t \\
\text { fermentation profile: volume: } 15 \mathrm{~L} \text {, time: } 3 \\
\text { - } 48 \mathrm{~h} \text {, air flow: } 5 \text { - } 20 \mathrm{~L} \mathrm{~min}{ }^{-1} \text {, agitation } \\
\text { rate: } 150 \text { - } 1350 \mathrm{rpm}, \mathrm{DO}: 95-35 \%\end{array}$ & A maximum Tx: $16,552 \mathrm{SBU} \mu \mathrm{L}^{-1}$ & $\begin{array}{l}\text { The Tx was directly associated with } \\
\text { the protease activity. }\end{array}$ & [151] \\
\hline & - Method: solid state fermentation: & The mixture of SW (ii) gave the maximum & The solid culture media (SL, SW SS & [147] \\
\hline & $\begin{array}{l}\text { Fermentation: substrate ( } 4 \text { types): (i) sludge } \\
\text { (SL), (ii) sludge + wheat roughage (SW); } \\
\text { (iii) sludge + straw powder (SS); (iv) } \\
\text { commercial culture (CM), pH: 7.2, CT: } 80 \\
\text { h. }\end{array}$ & 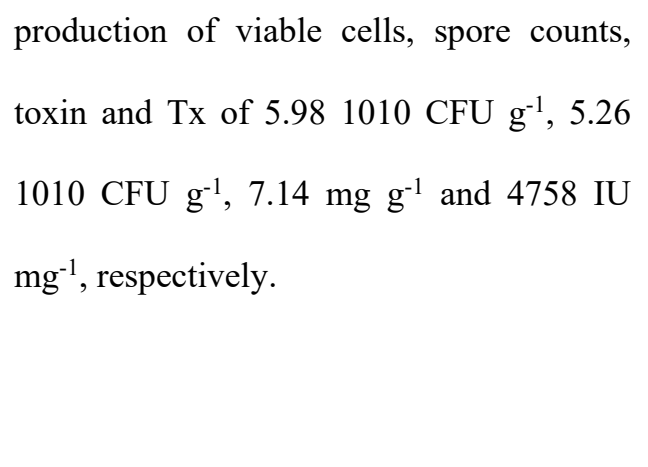 & $\begin{array}{l}\text { and } \mathrm{CM} \text { ) supported Bt production } \\
\text { under solid state fermentation. } \\
\text { The highest } \mathrm{Tx} \text { during the } \\
\text { fermentation of SW and } \mathrm{CM} \\
\text { indicated that Tx potency highly } \\
\text { dependence on the type of substrate. }\end{array}$ & \\
\hline
\end{tabular}




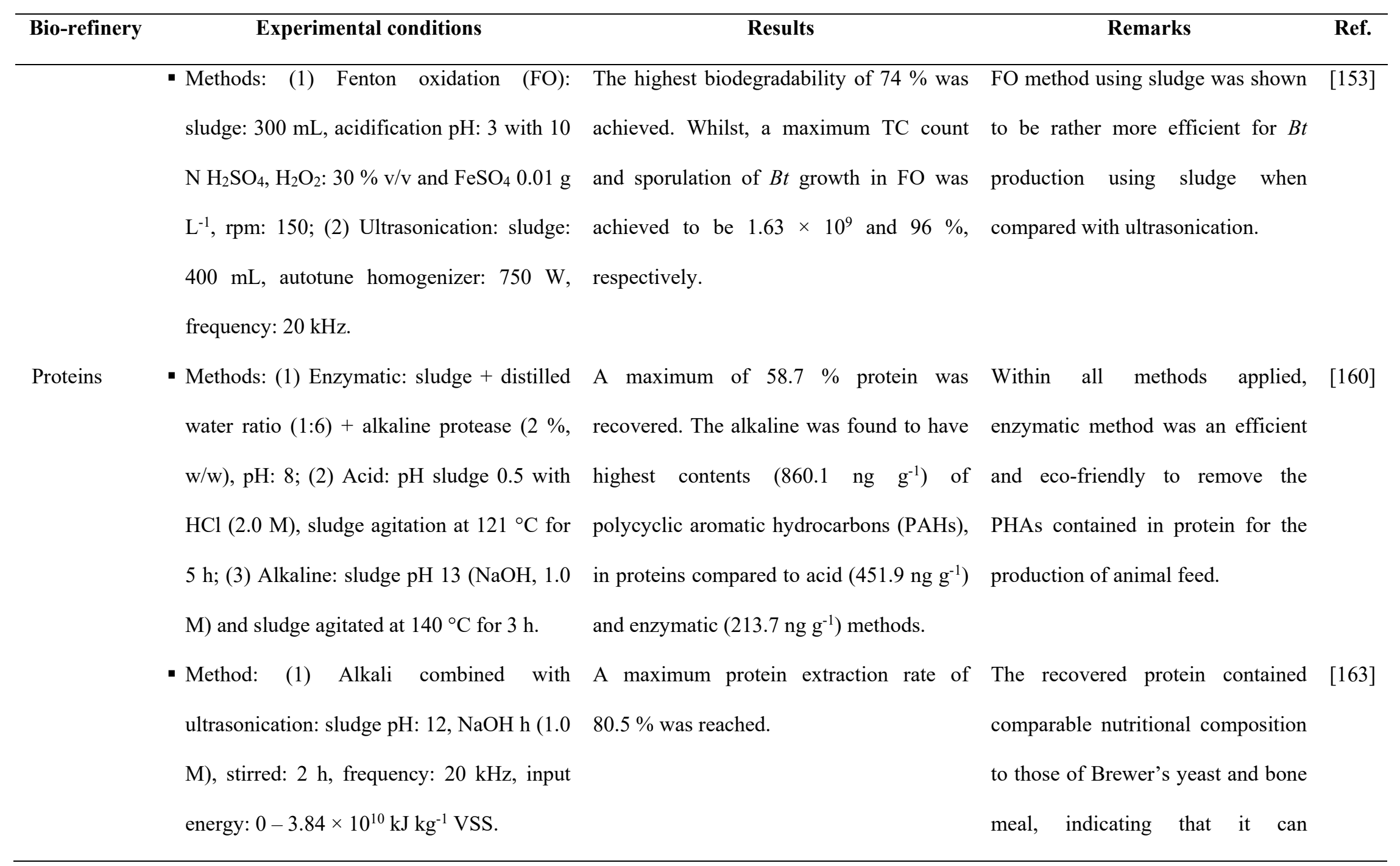


technically be used as animal feed.

- Methods: colorimetric methods (Lowry, The protein was found as a main The selected methods for [161]

modified Lowry, and the BCA): sludge: 0.5 component representing $50 \%$ of characterization of OM exhibited to

and $0.1 \mathrm{~mL}$, linearity for Lowry and the biochemical portion.

be appropriate for WAS analysis

modified Lowry: 0 to $100 \mathrm{mg}_{\mathrm{BSA}} \mathrm{L}^{-1}$,

with a good recovery of the VMs.

linearity for BCA: $0-2000 \mathrm{mg}_{\mathrm{BSA}} \mathrm{L}^{-1}$. 


\section{RESOURCE RECOVERY AND POLLUTION CONTROL FOR SEWAGE}

\section{SLUDGE}

\subsection{Nutrients}

WAS contains considerable amounts of nutrients, particularly P total solids (TS, $0.5-$ $0.7 \%)$ and $\mathrm{N}(2.4-5.0 \% \mathrm{TS})[3]$, these nutrients exist primarily in the form of proteinaceous material. The disintegration and solubilization of WAS and its later transition to ammonia and phosphates could possibly lead the way to produce magnesium ammonium phosphate (struvite), which is an excellent plant fertilizer and can be employed directly for land application [165-167].

About $1 \mathrm{~kg} \mathrm{~N}$ and $1 \mathrm{~kg} \mathrm{P}$ in commercial fertilizer costs approximately US \$ 1.3 and US $\$ 2.6$, respectively. The DS of WAS possesses $\sim 1 \mathrm{~kg} \mathrm{P}$ and $1.2 \mathrm{~kg} \mathrm{~N}^{\text {inhabitant }}{ }^{-1}$ year $^{-1}$ corresponding to a cost of nearly US $\$ 4.2$. Regarding P recovery from WAS, the cost has been reported around 1.6 to 3.0 times higher than the commercial $\mathrm{P}$ in different studies $[168,169]$.

On the other hand, $\mathrm{P}$ is a limited non-renewable resource as there will be no $\mathrm{P}$ left in apatite mines within 150 years [3]. Therefore, it must be considered as a highly valued asset/product and recovered efficiently from WAS.

Recently, significant efforts have been made toward P recovery from WAS based on the precipitation of phosphoric minerals in the form of struvites, hydroxyapatites or calcium phosphates $[170,171]$. These P-recovery technologies have been developed and put into operation largely in the Japan and Netherlands $[170,172]$. However, their high operational cost US $\$ 52,100$ year $^{-1}$ (Table 7) for struvite recovery with low 
reimbursement level of US $\$ 16,100-21,200$ year $^{-1}$ has declared them outdated and economically unjustifiable $[173,174]$. Some researchers claim that struvite could be extracted via biological nutrient removal process before WWT, resulting in $80-85 \%$ of $\mathrm{P}$ recovery [174]. While others claim that struvite extraction will never be reasonably efficient because of the high ammonia demand [175]. However, recently, Wang et al. [176] studied MW and $\mathrm{NaOH}$ techniques for WAS treatment to release and recover the $\mathrm{P}$, for application as a fertilizer. The MW and $\mathrm{NaOH}$ released $34.2-43.73 \%$ of total $\mathrm{P}$. At $\mathrm{pH} 9.5$ and an $\mathrm{Mg}: \mathrm{P}$ ratio of $1.5: 1,23.48-32.07 \%$ of the total $\mathrm{P}$ was recovered as a result of crystallizing struvite. The total process cost to treat WAS was found to be $\$ 85-$ $103 \mathrm{DT}^{-1}$ WAS. Therefore, more research on struvite extraction is required to counter aforementioned uncertainties.

The P-recovery from WAS incineration ashes is also under investigation nowadays [177-180]. These ashes contain high amounts of $\mathrm{P}$, mainly due to the considerable volume reduction of up to $90 \%$ [181]. Generally, the P content in WAS varies from $1-$ $5 \%$ (may reach up to $\sim 15 \%$ if any suitable technology is employed), whereas its content in ashes varies from $5-11 \%$ (more than $20 \%$ in specific case) [34, 169]. In addition, Cieślik et al. [174] stated that P-recovery could be $5-10$ times higher from ashes compared to that from WAS directly, but unfortunately viability of such technologies is proved only in large scale treatment plants, primarily because of the need to incur large capital costs associated with building a facility which meets all the environmental standards for WAS incineration. Le et al. [180] demonstrated the reuse of P resources from WAS ash in a pilot scale circulating FD kiln. The sample was mixed with $2-10$ wt. $\%$ of calcium oxide $(\mathrm{CaO})$. The temperature was varied from $750-950{ }^{\circ} \mathrm{C}$. The $\mathrm{P}$ 
released from WAS was deposited in bottom ash (89.29 \%) and fly ash (5.61 \%), respectively. Moreover, results suggested that higher temperature and more dose of $\mathrm{CaO}$ were advantageous for the conversion of non-apatite inorganic phosphorus to apatite $\mathrm{P}$.

On the other hand, Shih et al. [171] treated synthetic wastewaters containing high concentrations of $\mathrm{P}$ via crystallization of struvite in a FD crystallizer. The higher phosphate removal and crystallization ratio of $96 \%$ and $93.5 \%$, respectively, were obtained at optimum conditions, namely $\mathrm{pH}$ of 9.5 , molar ratio $\mathrm{Mg} / \mathrm{N} / \mathrm{P}$ of $1.3 / 4 / 1$, struvite seed dose of $30 \mathrm{~g} \mathrm{~L}^{-1}$, total flow rate of $12 \mathrm{~mL} \mathrm{~min}^{-1}$, and reflux of $120 \mathrm{~mL} \mathrm{~min}^{-1}$.

Similarly, other investigations have also reported a remarkable P content of $>95 \%$ and ammonia $>50 \%$ solubilization via various combined thermochemical treatments [182-184]. Guedes al. [181] and Couto et al. [185] presented a viable method for Precovery by an electro dialysis approach from WAS. The process gave a total yield of 30 $-85 \%$ including some amounts of gypsum, thus necessitating further research to evaluate the opportunity of utilizing residues as dopants for construction materials.

The technological advancement refereeing to commercial scale P-recovery includes Aqua Reci (AR), OSTARA, SUSAN and KREPO, which are based on physicochemical and thermal treatment to dissolve $\mathrm{P}$ and then recover it by precipitation. The AR process, a commercial technology, has been established in Sweden to recover both P and energy using combined Supercritical Water Oxidation technology. The process can efficiently recover $\sim 100 \%$ of $\mathrm{P}$ by means of $\mathrm{HCl}$ and $\mathrm{H}_{2} \mathrm{SO}_{4}$ with $2 \mathrm{~h}$ of reaction time and at $90{ }^{\circ} \mathrm{C}$ [186]. Another process called OSTARA has been employed to recover P from WAS stream using magnesium chloride $\left(\mathrm{MgCl}_{2}\right)$ at the city of Edmonton, Canada. The process was established in 2007 , and is expected to produce $200-250 \mathrm{Mt} \mathrm{year}^{-1}$ of struvite [3, 
187, 188]. A commercial scale plant $\left(45,000 \mathrm{~m}^{-3}\right.$ day ${ }^{-1}$ treatment capacity) with the technology for P-recovery (>90\%) as struvite (about $550 \mathrm{~kg} \mathrm{day}^{-1}$; equivalent to $0.01 \mathrm{~kg}$ struvite $\mathrm{m}^{-3}$ ) has been in operation at the Lake Shinji East Clean Center in Japan [189]. Moreover, the Crystalactor ${ }^{\circledR}$ technology, was commercialized in Netherlands. However, this technology was challenged by high cost of P-recovery and thus considered as uneconomical [190]. The high cost of P-recovery from WAS is considered the major obstacle in the scaling up of the explored technologies. As a result, it is likely that a new technology should be proposed that may allow not only the recovery of valued phosphoric material, but also all-inclusive management of all wastes produced during WAS thermal treatment. The limitations and benefits of presented P recovery approaches from sludge are presented in Table 7. 
Table 7. Recognized benefits and limitations of selected methods for P recovery from sludge [174, 191-195].

\begin{tabular}{|c|c|c|c|c|c|c|}
\hline \multirow{2}{*}{$\begin{array}{l}\text { P recovery methods } \\
\text { Direct use of WAS in }\end{array}$} & \multicolumn{2}{|r|}{ Process sub-classification } & \multicolumn{2}{|r|}{ Recognized benefits } & \multicolumn{2}{|r|}{ Limitations } \\
\hline & 1) & Stabilization via & 1) & Low cost technologies, even if & 1) & Long stabilization periods at lower temperature. \\
\hline \multirow[t]{7}{*}{ agricultural land } & & earthworms & & the small quantities of WAS is & 2) & Risk of environmental pollution through high organic \\
\hline & 2) & Composting & & used. & & carbon loads, pathogens and parasites, aromatic \\
\hline & 3) & Stabilization in pools & 2) & The management of all sludge & & hydrocarbons and HMs. \\
\hline & 4) & Drying and pellet & & with lower HMs concentration & 3) & Limited applications (i.e. soil conditioning and \\
\hline & & production & & is possible if earthworm & & fertilizers). \\
\hline & & & & stabilization is employed. & 4) & Based on soil remediation strategy, these \\
\hline & & & & & & technologies are opposed by the EU. \\
\hline incinerated & 1) & Incineration & 1) & Partial reimbursement of & 1) & High operational cost \\
\hline \multirow[t]{6}{*}{ ashes } & 2) & Acidic extraction & & expenditures. & 2) & Risk of environmental pollution through \\
\hline & 3) & Thermochemical & 2) & Highly efficient WAS & & organic pollutants and chlorinated species. \\
\hline & & treatment & & management with inspiring $\mathrm{P}$ & 3) & Complex procedures. \\
\hline & 4) & Cementing & & recovery. & 4) & Obstacles with achieving high strength building \\
\hline & & & 3) & Substantial savings related & & materials. \\
\hline & & & & with sludge disposal, with & 5) & The technology is economical only if large amounts \\
\hline
\end{tabular}


4) Facility of simultaneous HMs treatment.

5) Energy recovery.

6) Processing is less odours.

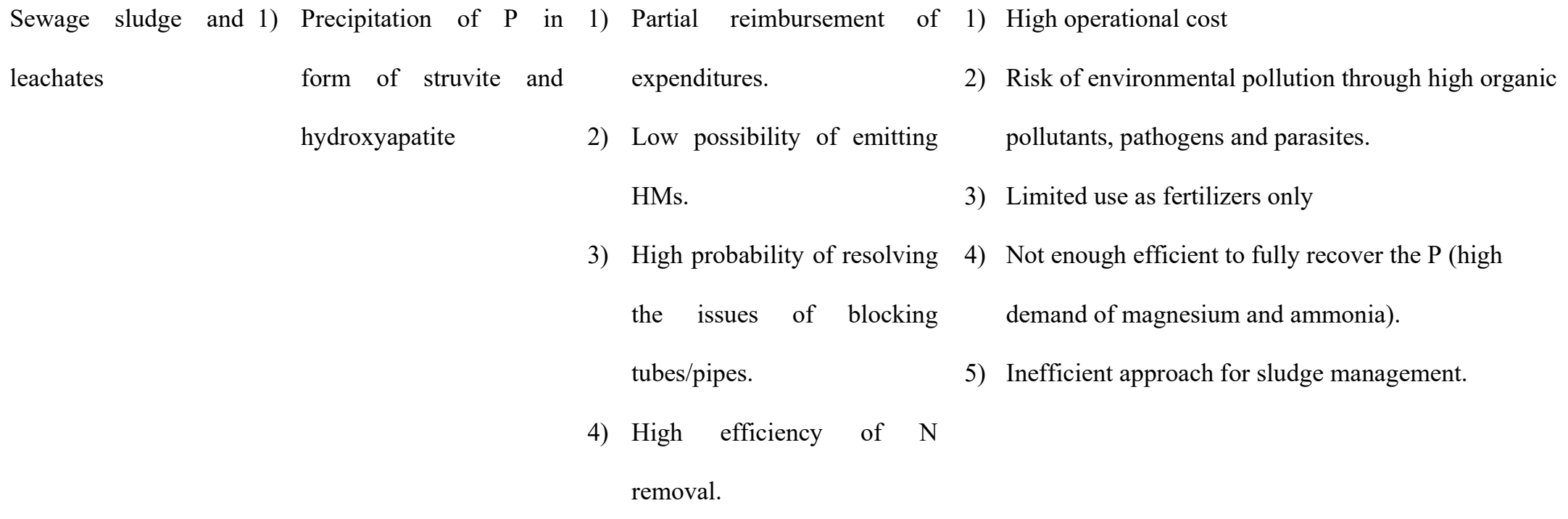




\subsection{Reduction and immobilization of heavy metals in sewage sludge products}

WAS has been under vigilance due to the high concentration of HMs such as chromium $(\mathrm{Cr})$, copper $(\mathrm{Cu})$, zinc $(\mathrm{Zn})$, lead $(\mathrm{Pb})$, cadmium $(\mathrm{Cd})$, nickel $(\mathrm{Ni})$, arsenic (As) mercury $(\mathrm{Hg})$ and selenium (Se). Table 8 shows the comparison of HMs content from different sources and a group of hazardous inorganic compounds examined in WAS. The presence of such metallic species in high concentrations can be a problematic case for value-added chemicals and extraction of biochemical materials as well as for energy recovery from WAS [196].

Referring to WAS thermal conversion via gasification and pyrolysis technologies, TEs typically exist in the gaseous stream, liquid pyrolysis products, and residual biochar. It is reported that the volatilization of TEs is clearly associated to their boiling point [197]. Consequently, higher gasification temperatures opposed to pyrolysis result in an enhanced gaseous product contamination risk and henceforth the significance of monitoring the HMs distribution in the gasification is more. Various gasification studies have demonstrated the potential routes of HMs to various process products [197]. He et al. [198] conducted the pyrolysis with a sequential extraction procedure in electric furnace, mainly focusing on fractionation of $\mathrm{HMs}$ (e.g. $\mathrm{Zn}, \mathrm{Pb}, \mathrm{Cu}$ and $\mathrm{Cd}$ ) in WAS and its residues which were generated after pyrolysis at temperatures ranging from 250 to $700{ }^{\circ} \mathrm{C}$. The $\mathrm{Cd}$ was volatilized in the off-gas at $700{ }^{\circ} \mathrm{C}$ and decreased in the residues. In addition, $\mathrm{Cu}, \mathrm{Pb}$ and $\mathrm{Cd}$ in the WAS and pyrolysis residues, were primarily bounded to $\mathrm{OM}$ and sulphides, whereas $\mathrm{Zn}$ was bounded to Fe and Mn oxides 
Table 8. Heavy metal contents in different biomass materials [199, 200].

\begin{tabular}{|c|c|c|c|c|c|c|c|c|}
\hline \multirow[t]{2}{*}{ Feedstock } & \multicolumn{7}{|c|}{ Heavy metals (mg kg ${ }^{-1}$ dry basis) } & \multirow[b]{2}{*}{ As } \\
\hline & Cd & $\mathrm{Cr}$ & $\mathrm{Cu}$ & $\mathbf{H g}$ & $\mathbf{N i}$ & $\mathbf{P b}$ & Zn & \\
\hline \multirow[t]{2}{*}{ WAS } & $<1-$ & $10-$ & & \multirow[t]{2}{*}{2.7} & $2-$ & $13-$ & $101-$ & $3-$ \\
\hline & 3410 & 990,000 & 2300 & & 179 & 465 & 49,000 & 230 \\
\hline Paper sludge & $<0.4$ & 110 & 310 & 1000 & - & 160 & 470 & 8 \\
\hline Paper sludge & 350 & 100 & 450 & - & 480 & 480 & 170 & - \\
\hline Wheat straw & 1.0 & 25 & 0.06 & 6 & - & - & - & 0.18 \\
\hline Beech wood & 1.0 & 2.5 & 43 & 0.12 & - & 33 & 15 & 3.5 \\
\hline Recovered & & & & & & & & \\
\hline fuel & 24 & 1020 & 2800 & - & 209 & 1100 & - & 37 \\
\hline
\end{tabular}

Hwang et al. [201] investigated the distribution of $\mathrm{HMs}$ such as $\mathrm{Cr}, \mathrm{Cd}, \mathrm{Zn}, \mathrm{Pb}, \mathrm{Cu}, \mathrm{K}$, $\mathrm{Na}$ and $\mathrm{Mg}$ present in pyrolysis residue of WAS (obtained at $500{ }^{\circ} \mathrm{C}$ ) in column experiments under simulated landfill conditions and the bottom ash of WAS incineration (achieved at 900 to $1000{ }^{\circ} \mathrm{C}$ ) to compare the environmental loads of the leachates depending on thermal treatment. Most of the HMs in the WAS remained immobile in the residues without being volatilized except $\mathrm{Cd}, \mathrm{Pb}$, and $\mathrm{Zn}$. Although the residues comprised more of surplus OM than that of ash, their carbon emission into the leachate under aerobic conditions were comparable to that of ash under anaerobic conditions. Therefore, it was concluded that pyrolysis of contaminated WAS limited to $500{ }^{\circ} \mathrm{C}$ temperatures reduces the emissions of HMs from produced char in landfill, unlike other 
pyrolysis studies [201-203] conducted at higher temperatures, making it a promising method of treating WAS before landfilling.

Contemplating the consequences of potentially harmful HMs during gasification, it should be noticed that ash dust is a chief carrier of (specially $\mathrm{Cd}$ and $\mathrm{Pb}$ ) in turbulent waste gasification routes; therefore, if the gasification occurs under non-turbulent conditions, particulate ash emissions are almost eliminated [197]. Currently, Saveyn et al. [197] have studied the fate of metallic species during WAS gasification, indicating that HMs such as $\mathrm{Cu}, \mathrm{Pb}$, and $\mathrm{Zn}$ were nearly retained in the char, whilst $\mathrm{Hg}$ and $\mathrm{Cd}$ were depleted from the WAS and ended up in the different downstream sections like char residues, condensate liquids, and particles in filters. Similar trend for $\mathrm{Cd}$ was observed during co-gasification of solid recovered fuel and coal [204]. The transformation of HMs $(\mathrm{Zn}, \mathrm{Pb}, \mathrm{Ni}, \mathrm{Cu}, \mathrm{Cr}$ and $\mathrm{Cd}$ ) from gasification of WAS to by-products and their major accumulation in solid and liquid residues, i.e. ash, char and tar, have been reported by several studies $[75,200,205]$. On the other hand, $\mathrm{Hg}$ and As due to high volatility at high temperatures can be entirely mobilized with aerosol particles [4].

Generally, the type, speciation and concentration of HMs depend on the sources of raw sludge, which majorly pass into products at high operating temperatures used for thermochemical conversion processes. The scheme of linking WAS and biofuel production can be introduced as a promising approach. However, implementation of appropriate thermochemical processes and its optimum operating conditions are highly desirable based on the type and content of HMs in the WAS, as well as, reactor design and the presence of probable pre-/post-treatment techniques [206]. For example, pyrolysis process at lower temperatures around 400 to $600{ }^{\circ} \mathrm{C}$ has been found safer and 
efficient compared to gasification, liquefaction and incineration with higher temperatures/pressure, thereby increasing the emission of HMs into gaseous phase. Moreover, low temperature pyrolysis could contribute a considerable reduction on contamination level, bioavailability and environmental risk of HMs [67, 206, 207].

Even though, thermochemical processes can be suggested as a promising pathway for clean bioenergy recovery from WAS contaminated with HMs, still they are in infancy stages in terms of implication of pre-/post-treatment towards the immobilization and/or minimization of HMs transfer to the products [71]. For example, in some research studies, the implication of hydrothermal treatment prior to pyrolysis has been introduced as an effective method to accumulate the major amount of HMs in the biochar [71]. Besides, other studies have shown the considerable effect of operating reactors equipped with post-treatment technologies, such as hot-gas filter, $[208,209]$ cyclone, $[210,211]$ etc., to minimize the HMs emission from the thermochemical conversion of other contaminated biomass. Moreover, the blends of sewage sludge with other clean biomass, such as algae, sawdust, etc., has been also introduced to enhance the processes efficiency, to improve the characteristics of biofuel, and to reduce contamination resulted from diluting inorganic and toxic compounds [4]. In addition, the toxicity/risk of HMs, particularly $\mathrm{Cu}$ and $\mathrm{Zn}$, could be reduced through dewatering the sludge prior to utilization by pyrolysis or liquefaction technologies [212]. Therefore, it is anticipated that the implementation of aforementioned policies, i.e. operating reactor at optimum conditions and equipped with post-treatment technologies, could be practical to prevent or minimize the emission of HMs during thermochemical conversion of WAS. As outlook, the implication of proper pretreatment techniques using potential sorbents, hydrothermal and leaching pretreatment 
could be a good policy to hinder the transfer of HMs to the products, which to our best knowledge has not been sufficiently addressed.

\subsection{Removal of micro-pollutants}

Apart from HMs, sludge is also comprised of a wide range of micropollutants (MPs). MPs are mainly classified into three categories: (i) pharmaceutical products (PHPs) such as anti-inflammatory drugs, antibiotics, X-ray contract media and $\beta$-blockers; (ii) personal care products (PCPs) such as steroids, analgesics, synthetic hormones, fragrances, cosmetics, sun screens, lipid regulators and shampoos; and (iii) endocrine disrupting chemicals (EDCs) such as estrone (E1), 17 -estradiol (E2) and 17 $\alpha$ ethinylestradiol (EE2) [213, 214]. The serious environmental and human risks associated with the contamination of WWTP sludge (through biosoild amended soils, and groundwater) have been widely reported in literature [33, 215-217]. This results mainly due to the hydrophobicity or propensity of pollutants to be adsorbed on particles (sludge) during primary and biological treatments in WWTPs.

Therefore, effective removal strategies for OMPs are urgent and arduous task to limit the contamination of environment. Today, various efforts have been made for removal/transformation of OMPs during sludge treatment via AD. Example include Nonylphenol ethoxylates and steroid estrogens via a lab scale reactor running under mesophilic $\left(35^{\circ} \mathrm{C}\right)$ and thermophilic $\left(55^{\circ} \mathrm{C}\right)$ trials [218], pharmaceutical products via two semi-continuous lab reactors under mesophilic $\left(38^{\circ} \mathrm{C}\right)$ and thermophilic $\left(55^{\circ} \mathrm{C}\right)$ conditions [219]. The results obtained from above studies concluded that the temperature (mesophilic or thermophilic) is not an important parameter, except for carbamazepine and nonylphenol, whilst naproxen, trimethoprim and sulfamethoxazle are substantially 
removed. On the contrary, the removal efficiencies of several studies for OMPs removal are rather contentious; they have shown low $(<25 \%)$ or no removal of E1, E2, EE2 (hormones) [219, 220], musk fragrances [221, 222], diclofenac [219, 223], ibuprofen $[219,221]$ and triclosan [223]; whereas other researchers disagree. For example, a study conducted by Carballa et al. [224] showed that hormones and musk fragrances were effectively removed up to $\sim 70 \%$ and $\sim 95 \%$, respectively; also, Samaras et al. [214] reported removals more than $90 \%$ for diclofenac and ibuprofen, and within the range of $60-80 \%$ for triclosan. The reasons of these inconsistencies remain vague. Further research in this area is highly valuable to deeply assess the impact of WAS treatmetns on the fate of MPs.

\section{PREFERENCE OF WAS VS. LIGNOCELLULOSIC BIOMASS}

Herein, the preference and/or comparison of WAS over other lignocellulosic biomasses (LBs) is discussed concisely. The pros and cons of WAS compared to LBs (i.e. agricultural residues and forestry waste) are mainly attributed to their basic structural and compositional differences. As previously described, WAS possesses a semi-solid structure with $59-88 \%$ w/v biodegradable OMs [1, 3]. Whereas, generally most of the lignocellulosic biomass comprises of cellulose $(30-50 \%)$, hemicellulose ( $20-35 \%)$ and lignin (10 - $27 \%)$ [149]. Firstly, lignocellulosic biomass is known to be the nonebiodegradable due to its complex chemical composition [225], making it difficult to produce high yield and quality biofuels, value-added products and chemicals [226]. In order to cope with these challenges, these biomasses require various pretreatments, such as crushing, cracking, drying, preheating [227, 228] and more costly and sophisticated (thermo-)chemical operations to enhance the accessibility of biomass for conversion 
reactions [229-231]. For instance, various thermochemical processes have been investigated to produce bio-oils or other form of biofuels from LBs, but the quality of biofuels still remains a big challenge, which needs further catalytic, separation or purification reactions to be upgraded [232-235]. Likewise, challenging fractionation procedure to separate cellulose from lignin and hemicellulose can be remarked to emphasize the controversial practicability of an expensive and/or hazardous pretreatment approaches, like ionic liquids, eutectic/organic solvents, steam explosion, acid and alkaline methods, etc., to facilitate the conversion and saccharification processes or materials recovery from agricultural wastes [230, 236, 237]. Secondly, regardless of the high potential of LB for thermochemical biofuel production [238], relatively a low biological methane yield [239], limited value-added products [239, 240] and chemicals recovery [241].

On the contrary, as comprehensively discussed in this paper, the soft structure and rich OMs content endow WAS with adequate potential for the recovery of energy [3, 21, 72], nutrients [36, 165, 174], and value-added materials [126, 136, 147] using various thermochemical and biological etc., processes with/without implementing costly pretreatment or post-treatment stages. The WAS ashes can also be reused in cement mixtures to produce diverse construction materials, including brick, mortar, etc. [242, 243]. However, regardless of aforementioned advantages of using WAS over LB, there are some limitations associated with each one, which can be compensated using their coprocessing, particularly for energy recovery. For example, LB on account of the high $\mathrm{C} / \mathrm{N}$ ratio and bio-recalcitrant compounds cannot reach to higher biogas yield [239, 244]. Whereas, WAS can be anaerobically biodegraded with high biogas yield of $270-385$ 
$\mathrm{mL} \mathrm{CH}_{4} \mathrm{gVS}^{-1}[3,15-17]$. Therefore, the anaerobic co-digestion of WAS (holding low $\mathrm{C} / \mathrm{N}$ ratio) and lignocellulosic biomass (with medium or high $\mathrm{C} / \mathrm{N}$ ratio) under mesophilic and thermophilic condition seems to be a rational option to increase biogas yield[244]. Similarly, Chiang et al. [245] have elucidated that a mixed feedstock with higher ratio of WAS causes an enhancement of thermal reaction activity. The reason is also attributed to the less fixed carbon content of WAS, so that it could decrease the activation energy and consequently the significant increase of thermal reaction. On the other hand, WAS has a lower bio-oil yield of 32 wt. $\%$ and heating value of about $13-21 \mathrm{MJ} \mathrm{kg}^{-1}[8,57,58]$, compared to the lignocellulosic biomass with higher bio-oil yields of $40-50$ wt. \% and heating value of $16.79-19 \mathrm{MJ} \mathrm{kg}^{-1}[238,246,247]$. In addition, another major problem linked to the WAS are higher moisture content and lower syngas calorific value of $4-6$ MJ Nm${ }^{-3}[58,74]$, which can be compensated through co-pyrolysis, [248]-gasification, [73] -incineration [249, 250] and -liquefaction [251] of WAS with lignocellulosic biomass to high yield and quality usable energy in an environment friendly manner.

\section{SLUDGE TREATMENT SCENARIOS IN EU, USA AND CHINA}

Global WAS production is on a relentless growth curve and environmental quality requirements for WAS are becoming increasingly stringent, therefore disposal outlets are decreasing and economic pressures require low-cost solutions [252]. EU, USA and China represent a vast fraction of present world in terms of population, growth, technological advancements and, rules and strategies for environmental protection. The other countries in the world follow them as benchmarks especially in the arena of waste disposal and reuse. 


\subsection{European Union-15 countries}

Among EU-15 countries, over $76 \%$ of total WAS production belongs to Germany, UK, Italy, France and Spain as depicted in Fig. S1 (see Electronic Supporting Information, ESI). Figs. S1 and S2, WAS quantity in the EU-15 countries was around 10 million of DT in 2010 and it is estimated to reach to 10.5 million DT by 2020 [7, 70, 253].

According to EU landfill Directive, [254] landfill practice of wastes are forbidden. As a result, landfilling in EU-15 countries presenting a continuing decline between 2010 and 2020, from $11 \%$ to $4 \%$ (Fig. S3). Furthermore, WAS recycling has been a prevailing technology in EU-15 countries for soil conditioning and fertilization [7]. On the other side, HMs, pathogens and POPs often outweigh the soil's nutrients leading to the risk of eutrophication, acidification and GHG emissions [70, 255]. Therefore, WAS application for arable land will remain almost steady among EU-15 countries (43\% in 2010) expecting to attain $45 \%$ in 2020, owing to imposed legislative restrictions (Fig. S3) [70]. The highest proportion of WAS recycling in 2010 was observed in Luxemburg (90\%), followed by UK (75\%), Ireland (75\%), France (65\%), Spain (65\%), Portugal (50\%), Denmark (50\%) and Italy (25\%), indicating that the recycling was most preferred disposal practice in EU-15 countries except Netherlands (Fig. S2). The change in WAS recycling has been estimated for 2020 as follows: for Italy and France (10\%), Spain (5\%), Austria and Luxemburg (-10\%), and for UK and Germany (-5\%).

Although incineration is considered as a cost intensive process with potential environmental problems [256], most of EU-15 countries seem to invest in incineration facilities (Fig. S2 (A) and Fig. S3). The Netherlands demonstrates $100 \%$ incineration of the WAS produced, followed by Belgium (90\%), Germany (50\%), Denmark (45\%), 
Portugal (30 \%) UK (20\%), Italy (20\%), France (15\%) and Spain (10\%) (Fig. 2S (A)). The incineration shares based on 2020 estimation are predicted to increase as follows: Austria (45\%), Greece (40\%), Spain (15\%), Luxemburg (15\%), Italy, Ireland and Portugal (10 \%) (Fig. S2 (B)). The significant variations in incinerated WAS among EU15 countries are closely related to the incineration methods. WAS co-incineration with MSW, coal-fired power plants or cement kilns are preferred.[257, 258] Monoincineration practice is widely expanding in Germany, UK, and Denmark with 23, 11 and 5 dedicated WAS incinerators, respectively [7]. Mono-incinerators have proved to be a reliable approach to recover phosphorus from incineration ashes [258]. Moreover, modern incinerators should be capable of using resultant heat to generate their own electricity so that WAS treatment becomes energy-neutral.

\subsection{United States of America (USA)}

The USA employs WAS (biosolids) typically for arable land application as shown in Fig. S4. It adds the nutrients into soils, thereby providing more OMs and improving its holding capacity $[32,259]$. Referring to Fig. S4, over 8 million DT of WAS is annually produced ( 23 kg of WAS person ${ }^{-1}$ year $\left.^{-1}\right)$ in USA, $55 \%$ applied to arable land, $30 \%$ landfilled, and $15 \%$ incinerated [32]. The cost of arable land application, landfilling, and incineration are estimated to be $300-800,100-650$ and $300-500 \$ \mathrm{DT}^{-1}$, respectively. Moreover, local ordinances have forbidden WAS land use to curb the associated odors, pathogens and pollutants [32].

In terms of nutrients ( $\mathrm{N}$ and $\mathrm{P}$ ) recovery, the reported data [260] of 8 million DT of WAS recycled in arable land (55\%) (Fig. S4), with $\mathrm{N}$ and $\mathrm{P}$ contents of 3.4 and $2.3 \%$, respectively [32]. Consequently, the potential annual net flux is respectively $134,640 \mathrm{t} \mathrm{N}$ 
year $^{-1}$ and 91,080 t $\mathrm{P}$ year ${ }^{-1}$. Based on the data presented in the literature [261] regarding the annual nutrients consumption, aforementioned values could provide only $1.1 \%$ and $5.3 \%$ of the net annual $\mathrm{N}$ and $\mathrm{P}$ fertilizer consumption. Thus, recovered $\mathrm{N}$ and $\mathrm{P}$ do not seem significant enough to rely upon them as imperative nutrients source for land application. However, their removal from wastewater and prevention of eutrophication phenomenon in water bodies are still in the first priority. In terms of energy, around 16, 000 WWTPs are operating in U.S.A. However, only 544 of WWTPs have adopted AD technology for biogas production, and merely 106 of these are able to use the biogas produced for various applications such as electricity and/or thermal energy [262].

\subsection{China}

Over the last 20 years, China has been investing considerably in WWTPs. Currently, China has become the world's second largest WAS producer with around 5,797 WWTPs in 2014, generating 6.25 million DT equivalent to $\sim 4.5 \mathrm{~kg}_{\text {person }}{ }^{-1}$ year $^{-1}$, with an average annual growth of $13 \%$ [52]. On the other hand, more than $80 \%$ of the WAS has not been treated or disposed properly, and subsequently poses a great threat to both the public health and the environment [263]. As a result, China government has set a goal to start treating 5.18 MM of DT year-1 [52]. Fig. 2 illustrates the detailed WAS treatment/disposal options indicating that arable land application, sanitary landfill, AD, and incineration are the four most commonly employed routes in China. Hitherto, the mainstream routes applied in China are thickening, conditioning, and dewatering [52]. The thickening route reduces over $5 \%$ WAS moisture and the major pathways include flotation, mechanical and gravity thickening $[52,264]$. Moreover, the organic polymer 
electrolytes and inorganic coagulants (chemical conditioning) have been frequently applied routes for enhancement of WAS dewatering [52].

The accurate official data on WAS disposal is scarce, rather conflicting sources with dissimilar estimations [52, 265]. According to Yang et al. [52] over $84 \%$ of WAS is disposed by improper dumping. Concerning the proper disposal, sanitary landfill has been most widely used method, which accounts for $13 \%$, followed by land application $(2 \%)$, incineration $(0.4 \%)$ and building material production $(0.2 \%)$. Data reported by Wang et al. [265] showed that the most commonly employed disposal method is landfilling (63\%), followed by agricultural applications (14\%), and incineration (2\%). Moreover, the disposal method for approximately $21 \%$ of WAS is unknown.

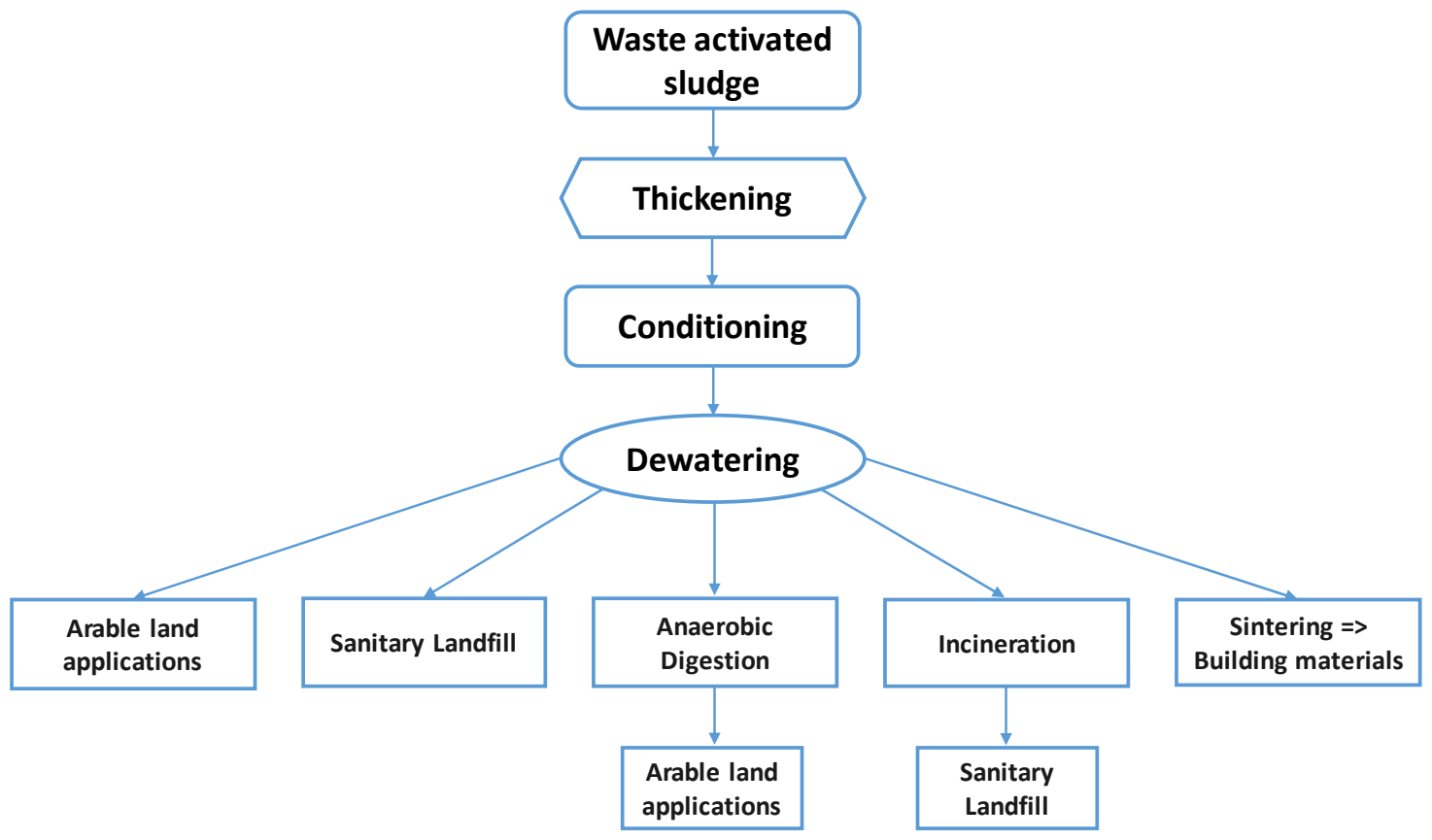

Fig. 2 Technical routes of WAS treatment and disposal in China [52].

The significant variations of data are attributed to WWTPs in China, because they do not send proper reports on the treatment and final disposal of their WAS [266]. Moreover, 
the cost of sanitary landfill, arable land application, incineration, building materials are estimated to be $72-96,240-280,240-260$ and $240-260 \$ \mathrm{DT}^{-1}$, respectively, whereas improper disposal only costs around $16-24 \$ \mathrm{DT}^{-1}$ [52]. Therefore, WWTPs and associated organizations typically opt for cheap disposal routes. In China only $50 \%$ of WWTPs adopted AD to stabilize WAS. However, only $30 \%$ of those $50 \%$ plants are operating the $\mathrm{AD}$ apparatus properly due to insufficient operational expertise and insufficient funding [52, 267]. Furthermore, the treatment efficiency of WAS by AD process is not sufficient due to high sand content and low volatile organic compounds [267]. According to Yang et al. [52] thickening-dewatering-AD and subsequent arable land application can be employed as the major technological route in the future. This route appears to be promising for large and moderate WWTPs due to the limited land availability in the cities and scarcity of energy supply in economically poor countries.

\section{FUTURE PERSPECTIVE}

Rapid increase in population and societal living standards will undoubtedly enhance the sludge generation to a vital extent. In the wake of lesser land-fill sites and stringent disposal regulations, a shift is required from conventional disposal to advanced valorization strategies. Numerous pathways are employed nowadays to explore the possibilities of energy extraction from sludge. However, complex composition of sludge such as the presence of very high amount of moisture, bacterial constituents (proteins, lipids, etc.), HMs and other contaminants (e.g. polycyclic aromatic hydrocarbons (PAHs), dioxins, furans) reduces the efficiency and safety of these processes and enhances their 
overall costs. In addition, it also demands special equipment / plant design to cater such a need.

Biological route such as $\mathrm{AD}$ is considered as the most appropriate sludge valorization technique but it suffers for poor efficiency and long processing time. Thermochemical pathways such as incineration, pyrolysis and gasification have improved efficiencies with faster processing and versatile end applications. However, they all are energy intensive for high moisture containing feedstock such as wet sludge. In addition, flue gases (in incineration) and syngas (in gasification) require conditioning and expensive clean-up prior to usage and emissions. Same is the case with pyrolysis derived bio-oil which also needs upgrading prior to its application. Therefore, innovation is needed in the existing pathways to eliminate these limitations. AD coupled with pyrolysis, co-combustion and co-incineration can be the viable routes provided the process economics is enhanced via proper process design and reduction in energy requirements. This may lead to the scale up of pilot plant studies to commercial level applications.

There can be other sustainable solutions for efficient and cost-effective disposal of sludge with simultaneous energy and materials recovery. An integrated bio-refinery system could be designed focusing on reuse options rather than disposal pathways to generate power and recover all the possible resources. It will not only valorize the sludge but will also aid in reducing adverse environmental impact to a significant extent. This integrated system can be designed based on the local circumstances such as composition and amount of sludge, economy, topography, and weather conditions. In addition, sludge disposal and application models given by EU and USA can serve as references for other developing nations. On the whole, application of advanced technologies for WAS 
management must transform from treatment of a liability toward a promising opportunity (i.e. recovery of embedded energy, metals, and nutrients), while enduring to protect the environment and public health.

\section{ACKNOWLEDGEMENT}

This work was supported by National Key Technology R\&D Program of China (grant number 2015BAD21B05); and Tsinghua University Initiative Scientific Research Program (grant number: 20161080094).

\section{ABBREVIATIONS}

$\mathrm{AD}$

Anaerobic digestion

$\mathrm{AC}$

Activated carbon

Bt Bacillus thuringiensis

BES Bioelectrochemical systems

BSA Bovine Serum Albumin

BCA Bicinchonic Acid

COD Chemical oxygen demand

$\mathrm{C} / \mathrm{N} \quad$ Carbon to nitrogen ratio

CER Cation exchange resin

CCE Carbon conversion efficiency

CGE Cold gas efficiency

C-GT Carver-Greenfield technology

CT Cycle time

DFC Down flow combustor

ER Equivalence ratio 


$\begin{array}{ll}\text { FB } & \text { Fluidized bed } \\ \text { GRT } & \text { Gas residence time } \\ \text { GHG } & \text { Greenhouse gas } \\ \text { GE } & \text { Gasification efficiency } \\ \text { HMs } & \text { Heavy metals } \\ \text { HR } & \text { Heating rate } \\ \text { LHV } & \text { Lower heating value } \\ \text { LBs } & \text { lignocellulosic biomasses } \\ \text { MW } & \text { Microwave } \\ \text { MWe } & \text { Megawatt } \\ \text { Mt } & \text { Metric tons } \\ \text { MSW } & \text { Municipal solid waste } \\ \text { MFCs } & \text { Microbial fuel cells } \\ \text { OMs } & \text { Organic matters } \\ \text { OLR } & \text { Organic loading rates } \\ \text { OFS } & \text { Oil-from-Sludge technology } \\ \text { PHA } & \text { Polyhydroxyalkanoates } \\ \text { POPs } & \text { Persistent organic pollutants } \\ \text { PVC } & \text { Polyvinylchloride } \\ \text { RPM } & \text { Revolution per minute } \\ \text { SSBT } & \text { Siemens Schwell-Brenna technology } \\ \text { Tx } & \text { Entomotoxicity } \\ \text { TEs } & \text { Trace elements } \\ \text { TS } & \text { Total solids } \\ \text { TD } & \text { Volatile fatty acids } \\ \text { VFAs } & \text { Waste activated sludge } \\ \text { WMas shift }\end{array}$


WWTP Wastewater treatment plant

WWT Wastewater treatment

\section{REFERENCES}

[1] K. Bibby, J. Peccia, Identification of viral pathogen diversity in sewage sludge by metagenome analysis, Environmental science \& technology 47 (2013) 1945-1951.

[2] J. Zhang, W. Zuo, Y. Tian, L. Chen, L. Yin, J. Zhang, Sulfur Transformation during Microwave and Conventional Pyrolysis of Sewage Sludge, Environmental science \& technology 51 (2016) 709-717.

[3] V.K. Tyagi, S.-L. Lo, Sludge: A waste or renewable source for energy and resources recovery?, Renewable and Sustainable Energy Reviews 25 (2013) 708-728.

[4] P. Manara, A. Zabaniotou, Towards sewage sludge based biofuels via thermochemical conversion-a review, Renewable and Sustainable Energy Reviews 16 (2012) 2566-2582.

[5] W. Rulkens, Sewage sludge as a biomass resource for the production of energy: overview and assessment of the various options $\dagger$, Energy \& Fuels 22 (2008) 9-15.

[6] X. Wang, J. Li, R. Liu, R. Hai, D. Zou, X. Zhu, N. Luo, Responses of Bacterial Communities to CuO Nanoparticles in Activated Sludge System, Environmental Science \& Technology 51 (2017) 5368-5376.

[7] A. Kelessidis, A.S. Stasinakis, Comparative study of the methods used for treatment and final disposal of sewage sludge in European countries, Waste Management 32 (2012) 1186-1195.

[8] M. Samolada, A. Zabaniotou, Potential application of pyrolysis for the effective valorisation of the end of life tires in Greece, Environmental Development 4 (2012) 73-87.

[9] D. Deublein, A. Steinhauser, Biogas from Waste and Renewable Resource (Weinhem, WileyVCH Verlag GmbH \& Co. KgaA, 2008.

[10] I.A. Nges, J. Liu, Effects of solid retention time on anaerobic digestion of dewatered-sewage sludge in mesophilic and thermophilic conditions, Renewable Energy 35 (2010) 2200-2206.

[11] G. Esposito, L. Frunzo, A. Panico, F. Pirozzi, Modelling the effect of the OLR and OFMSW particle size on the performances of an anaerobic co-digestion reactor, Process biochemistry 46 (2011) 557-565.

[12] D. Devlin, S. Esteves, R. Dinsdale, A. Guwy, The effect of acid pretreatment on the anaerobic digestion and dewatering of waste activated sludge, Bioresource Technology 102 (2011) 40764082.

[13] W. Qiao, X. Yan, J. Ye, Y. Sun, W. Wang, Z. Zhang, Evaluation of biogas production from different biomass wastes with/without hydrothermal pretreatment, Renewable Energy 36 (2011) 3313-3318.

[14] Y. Cao, A. Pawłowski, Sewage sludge-to-energy approaches based on anaerobic digestion and pyrolysis: Brief overview and energy efficiency assessment, Renewable and Sustainable Energy Reviews 16 (2012) 1657-1665.

[15] B.E. Rittmann, P.L. McCarty, Environmental biotechnology: principles and applications. 2001, New York, USA: McGraw-Hill Series in Water Resources \& Environmental Engineering 173 569570 . 
[16] K. Sato, S. Ochi, M. Mizuochi, Up-to-date modification of the anaerobic sludge digestion process introducing a separate sludge digestion mode, Water science and technology 44 (2001) 143-147.

[17] X. Dai, X. Li, D. Zhang, Y. Chen, L. Dai, Simultaneous enhancement of methane production and methane content in biogas from waste activated sludge and perennial ryegrass anaerobic co-digestion: The effects of $\mathrm{pH}$ and $\mathrm{C} / \mathrm{N}$ ratio, Bioresource technology 216 (2016) 323-330.

[18] D. Traversi, V. Romanazzi, R. Degan, E. Lorenzi, E. Carraro, G. Gilli, Microbial-chemical indicator for anaerobic digester performance assessment in full-scale wastewater treatment plants for biogas production, Bioresource technology 186 (2015) 179-191.

[19] J. Zhao, L. Gui, Q. Wang, Y. Liu, D. Wang, B.-J. Ni, X. Li, R. Xu, G. Zeng, Q. Yang, Aged refuse enhances anaerobic digestion of waste activated sludge, Water Research 123 (2017) 724-733.

[20] P.W. Harris, T. Schmidt, B.K. McCabe, Evaluation of chemical, thermobaric and thermochemical pre-treatment on anaerobic digestion of high-fat cattle slaughterhouse waste, Bioresource Technology 244 (2017) 605-610.

[21] H.B. Nielsen, A. Thygesen, A.B. Thomsen, J.E. Schmidt, Anaerobic digestion of waste activated sludge - comparison of thermal pretreatments with thermal inter - stage treatments, Journal of chemical technology and biotechnology 86 (2011) 238-245.

[22] E. Ortega-Martinez, I. Sapkaite, F. Fdz-Polanco, A. Donoso-Bravo, From pre-treatment toward inter-treatment. Getting some clues from sewage sludge biomethanation, Bioresource technology 212 (2016) 227-235.

[23] G. Campo, A. Cerutti, M. Zanetti, G. Scibilia, E. Lorenzi, B. Ruffino, Enhancement of waste activated sludge (WAS) anaerobic digestion by means of pre-and intermediate treatments.

Technical and economic analysis at a full-scale WWTP, Journal of Environmental Management (2017).

[24] N. Naik-Dhungel, The Opportunities for and Benefits of Combined Heat and Power at Wastewater Treatment Facilities, Proceedings of the Water Environment Federation 2010 (2010) 557-566.

[25] F. Kretschmer, G. Neugebauer, R. Kollmann, M. Eder, F. Zach, A. Zottl, M. Narodoslawsky, G. Stoeglehner, T. Ertl, Resource recovery from wastewater in Austria: wastewater treatment plants as regional energy cells, Journal of Water Reuse and Desalination 6 (2016) 421-429.

[26] I.-S. Lee, P. Parameswaran, B.E. Rittmann, Effects of solids retention time on methanogenesis in anaerobic digestion of thickened mixed sludge, Bioresource technology 102 (2011) 10266-10272.

[27] H.H. Ding, S. Chang, Y. Liu, Biological hydrolysis pretreatment on secondary sludge: Enhancement of anaerobic digestion and mechanism study, Bioresource Technology 244 (2017) 989-995.

[28] C. Eskicioglu, K. Kennedy, R. Droste, Enhanced disinfection and methane production from sewage sludge by microwave irradiation, Desalination 248 (2009) 279-285.

[29] C. Chu, D. Lee, B.-V. Chang, C. You, J. Tay, "Weak" ultrasonic pre-treatment on anaerobic digestion of flocculated activated biosolids, Water research 36 (2002) 2681-2688.

[30] M.-H. Wu, C.-L. Lin, W.-C. Huang, J.-W. Chen, Characteristics of pervious concrete using incineration bottom ash in place of sandstone graded material, Construction and Building Materials 111 (2016) 618-624.

[31] O. Krüger, A. Grabner, C. Adam, Complete survey of German sewage sludge ash, Environmental science \& technology 48 (2014) 11811-11818.

[32] J. Peccia, P. Westerhoff, We should expect more out of our sewage sludge, Environ. Sci. Technol. 49 (2015) 8271-8276. 
[33] R. Mailler, J. Gasperi, G. Chebbo, V. Rocher, Priority and emerging pollutants in sewage sludge and fate during sludge treatment, Waste management 34 (2014) 1217-1226.

[34] L.M. Ottosen, G.M. Kirkelund, P.E. Jensen, Extracting phosphorous from incinerated sewage sludge ash rich in iron or aluminum, Chemosphere 91 (2013) 963-969.

[35] C. Vogel, R.M. Exner, C. Adam, Heavy metal removal from sewage sludge ash by thermochemical treatment with polyvinylchloride, Environmental science \& technology 47 (2012) 563-567.

[36] H. Xu, P. He, W. Gu, G. Wang, L. Shao, Recovery of phosphorus as struvite from sewage sludge ash, Journal of Environmental Sciences 24 (2012) 1533-1538.

[37] S. Donatello, D. Tong, C. Cheeseman, Production of technical grade phosphoric acid from incinerator sewage sludge ash (ISSA), Waste management 30 (2010) 1634-1642.

[38] R.P. Viader, P.E. Jensen, L.M. Ottosen, J. Ahrenfeldt, H. Hauggaard-Nielsen, Electrodialytic extraction of phosphorus from ash of low-temperature gasification of sewage sludge, Electrochimica Acta 181 (2015) 100-108.

[39] L.M. Ottosen, P.E. Jensen, G.M. Kirkelund, Electrodialytic separation of phosphorus and heavy metals from two types of sewage sludge ash, Separation Science and Technology 49 (2014) 1910-1920.

[40] T.P. Thomsen, Z. Sárossy, J. Ahrenfeldt, U.B. Henriksen, F.J. Frandsen, D.S. Müller-Stöver, Changes imposed by pyrolysis, thermal gasification and incineration on composition and phosphorus fertilizer quality of municipal sewage sludge, Journal of environmental management 198 (2017) 308-318.

[41] T. Murakami, Y. Suzuki, H. Nagasawa, T. Yamamoto, T. Koseki, H. Hirose, S. Okamoto, Combustion characteristics of sewage sludge in an incineration plant for energy recovery, Fuel Processing Technology 90 (2009) 778-783.

[42] R. Thorpe, B. Brampton, S. Robson, A. Perrault, Investigating the effect of an alternative feedstock on the performance of sludge powered generators: developing a theoretical model and analysing trial data, Proceedings of The IWA Specialist Conference On Sludge Management: Sludgetech 2017, International Water Association, 2017.

[43] A.G. Gorgec, G. Insel, N. Yağci, M. Doğru, A. Erdincler, D. Sanin, A. Filibeli, B. Keskinler, Comparison of energy efficiencies for advanced anaerobic digestion, incineration, and gasification processes in municipal sludge management, Journal of Residuals Science \& Technology 13 (2016).

[44] D. Fytili, A. Zabaniotou, Utilization of sewage sludge in EU application of old and new methods-a review, Renewable and Sustainable Energy Reviews 12 (2008) 116-140.

[45] MC, Metro council: Metropolitan Wastewater Treatment Plant: Renewable energy resources, 2013.

[46] F.C. Jorge, M.A.P. Dinis, Sewage sludge disposal with energy recovery: A review, Proceedings of the Institution of Civil Engineers-Waste and Resource Management, ICE Publishing, 2013, pp. 14-28.

[47] J. Hong, C. Xu, J. Hong, X. Tan, W. Chen, Life cycle assessment of sewage sludge coincineration in a coal-based power station, Waste management 33 (2013) 1843-1852. [48] J. Morais, R. Barbosa, N. Lapa, B. Mendes, I. Gulyurtlu, Environmental and socio-economic assessment of co-combustion of coal, biomass and non-hazardous wastes in a Power Plant, Resources, Conservation and Recycling 55 (2011) 1109-1118.

[49] Y. Han, G. Hwang, D. Kim, S. Park, H. Kim, Porous Ca-based bead sorbents for simultaneous removal of SO 2, fine particulate matters, and heavy metals from pilot plant sewage sludge incineration, Journal of hazardous materials 283 (2015) 44-52. 
[50] J.-g. Zhu, Y. Yao, Q.-g. Lu, M. Gao, Z.-q. Ouyang, Experimental investigation of gasification and incineration characteristics of dried sewage sludge in a circulating fluidized bed, Fuel 150 (2015) 441-447.

[51] Y. Tian, J. Zhang, W. Zuo, L. Chen, Y. Cui, T. Tan, Nitrogen conversion in relation to NH3 and $\mathrm{HCN}$ during microwave pyrolysis of sewage sludge, Environmental science \& technology 47 (2013) 3498-3505.

[52] G. Yang, G. Zhang, H. Wang, Current state of sludge production, management, treatment and disposal in China, Water research 78 (2015) 60-73.

[53] H. Ni, X.-M. Fan, H.-N. Guo, J.-H. Liang, Q.-R. Li, L. Yang, H. Li, H.-H. Li, Comprehensive Utilization of Activated Sludge for Preparation of Hydrolytic Enzymes, Polyhydroxyalkanoates and Water-Retaining Organic Fertilizer, Preparative Biochemistry and Biotechnology (2017). [54] S. Werle, R.K. Wilk, A review of methods for the thermal utilization of sewage sludge: The Polish perspective, Renewable Energy 35 (2010) 1914-1919.

[55] B. Khiari, F. Marias, F. Zagrouba, J. Vaxelaire, Analytical study of the pyrolysis process in a wastewater treatment pilot station, Desalination 167 (2004) 39-47.

[56] N. Gao, C. Quan, B. Liu, Z. Li, C. Wu, A. Li, Continuous pyrolysis of sewage sludge in a screwfeeding reactor: products characterization and ecological risk assessment of heavy metals, Energy \& Fuels 31 (2017) 5063-5072.

[57] M. Atienza-Martínez, I. Fonts, L. Lázaro, J. Ceamanos, G. Gea, Fast pyrolysis of torrefied sewage sludge in a fluidized bed reactor, Chemical Engineering Journal 259 (2015) 467-480.

[58] M. Atienza-Martínez, I. Rubio, I. Fonts, J. Ceamanos, G. Gea, Effect of torrefaction on the catalytic post-treatment of sewage sludge pyrolysis vapors using $\mathrm{\gamma}$-Al $2 \mathrm{O} 3$, Chemical Engineering Journal 308 (2017) 264-274.

[59] K.-H. Lin, N. Lai, J.-Y. Zeng, H.-L. Chiang, Temperature influence on product distribution and characteristics of derived residue and oil in wet sludge pyrolysis using microwave heating, Science of The Total Environment 584 (2017) 1248-1255.

[60] N. Gao, J. Li, B. Qi, A. Li, Y. Duan, Z. Wang, Thermal analysis and products distribution of dried sewage sludge pyrolysis, Journal of Analytical and Applied Pyrolysis 105 (2014) 43-48. [61] E.J. Leijenhorst, W. Wolters, L. van de Beld, W. Prins, Inorganic element transfer from biomass to fast pyrolysis oil: Review and experiments, Fuel Processing Technology 149 (2016) 96-111.

[62] J. Menendez, M. Inguanzo, J. Pis, Microwave-induced pyrolysis of sewage sludge, Water research 36 (2002) 3261-3264.

[63] E.-S. Park, B.-S. Kang, J.-S. Kim, Recovery of oils with high caloric value and low contaminant content by pyrolysis of digested and dried sewage sludge containing polymer flocculants, Energy \& Fuels 22 (2008) 1335-1340.

[64] H. Chen, D. Chen, L. Hong, Influences of activation agent impregnated sewage sludge pyrolysis on emission characteristics of volatile combustion and De-NOx performance of activated char, Applied Energy 156 (2015) 767-775.

[65] Y. Shen, Chars as carbonaceous adsorbents/catalysts for tar elimination during biomass pyrolysis or gasification, Renewable and Sustainable Energy Reviews 43 (2015) 281-295.

[66] T.N. Trinh, P.A. Jensen, K. Dam-Johansen, N.O. Knudsen, H.R. Sørensen, Influence of the pyrolysis temperature on sewage sludge product distribution, bio-oil, and char properties, Energy \& Fuels 27 (2013) 1419-1427.

[67] J. Jin, Y. Li, J. Zhang, S. Wu, Y. Cao, P. Liang, J. Zhang, M.H. Wong, M. Wang, S. Shan, Influence of pyrolysis temperature on properties and environmental safety of heavy metals in biochars derived from municipal sewage sludge, Journal of hazardous materials 320 (2016) 417426. 
[68] P. Devi, A.K. Saroha, Risk analysis of pyrolyzed biochar made from paper mill effluent treatment plant sludge for bioavailability and eco-toxicity of heavy metals, Bioresource technology 162 (2014) 308-315.

[69] T. Chen, Y. Zhang, H. Wang, W. Lu, Z. Zhou, Y. Zhang, L. Ren, Influence of pyrolysis temperature on characteristics and heavy metal adsorptive performance of biochar derived from municipal sewage sludge, Bioresource technology 164 (2014) 47-54.

[70] M.C. Samolada, A.A. Zabaniotou, Comparative assessment of municipal sewage sludge incineration, gasification and pyrolysis for a sustainable sludge-to-energy management in Greece, Waste Management 34 (2014) 411-420.

[71] X. Wang, C. Li, B. Zhang, J. Lin, Q. Chi, Y. Wang, Migration and risk assessment of heavy metals in sewage sludge during hydrothermal treatment combined with pyrolysis, Bioresource technology 221 (2016) 560-567.

[72] E. Roche, J.M. de Andrés, A. Narros, M.E. Rodríguez, Air and air-steam gasification of sewage sludge. The influence of dolomite and throughput in tar production and composition, Fuel 115 (2014) 54-61.

[73] L. Peng, Y. Wang, Z. Lei, G. Cheng, Co-gasification of wet sewage sludge and forestry waste in situ steam agent, Bioresource technology 114 (2012) 698-702.

[74] V.S. Sikarwar, M. Zhao, P. Clough, J. Yao, X. Zhong, M.Z. Memon, N. Shah, E.J. Anthony, P.S. Fennell, An overview of advances in biomass gasification, Energy \& Environmental Science 9 (2016) 2939-2977.

[75] S. Werle, Gasification of a Dried Sewage Sludge in a Laboratory Scale Fixed Bed Reactor, Energies 8 (2015) 8562-8572.

[76] E. Afif, P. Azadi, R. Farnood, Catalytic hydrothermal gasification of activated sludge, Applied Catalysis B: Environmental 105 (2011) 136-143.

[77] F. Kokalj, B. Arbiter, N. Samec, Sewage sludge gasification as an alternative energy storage model, Energy Conversion and Management (2017).

[78] A. Łamacz, A. Krztoń, A. Musi, P. Da Costa, Reforming of model gasification tar compounds, Catalysis letters 128 (2009) 40-48.

[79] A.K. Sharma, Experimental investigations on a $20 \mathrm{kWe}$, solid biomass gasification system, biomass and bioenergy 35 (2011) 421-428.

[80] Y.-K. Choi, J.-H. Ko, J.-S. Kim, A new type three-stage gasification of dried sewage sludge:

Effects of equivalence ratio, weight ratio of activated carbon to feed, and feed rate on gas composition and tar, $\mathrm{NH} 3$, and $\mathrm{H} 2 \mathrm{~S}$ removal and results of approximately $5 \mathrm{~h}$ gasification, Energy 118 (2017) 139-146.

[81] N. Gil-Lalaguna, J. Sánchez, M. Murillo, E. Rodríguez, G. Gea, Air-steam gasification of sewage sludge in a fluidized bed. Influence of some operating conditions, Chemical Engineering Journal 248 (2014) 373-382.

[82] N. Nipattummakul, I.I. Ahmed, S. Kerdsuwan, A.K. Gupta, Hydrogen and syngas production from sewage sludge via steam gasification, International Journal of Hydrogen Energy 35 (2010) 11738-11745.

[83] Y. Chen, L. Guo, W. Cao, H. Jin, S. Guo, X. Zhang, Hydrogen production by sewage sludge gasification in supercritical water with a fluidized bed reactor, International Journal of Hydrogen Energy 38 (2013) 12991-12999.

[84] B. Zhang, S. Xiong, B. Xiao, D. Yu, X. Jia, Mechanism of wet sewage sludge pyrolysis in a tubular furnace, International Journal of Hydrogen Energy 36 (2011) 355-363.

[85] J.M. de Andrés, E. Roche, A. Narros, M.E. Rodríguez, Characterisation of tar from sewage sludge gasification. Influence of gasifying conditions: Temperature, throughput, steam and use of primary catalysts, Fuel 180 (2016) 116-126. 
[86] M. Campoy, A. Gómez-Barea, D. Fuentes-Cano, P. Ollero, Tar reduction by primary measures in an autothermal air-blown fluidized bed biomass gasifier, Industrial \& Engineering Chemistry Research 49 (2010) 11294-11301.

[87] T.-Y. Mun, J.-O. Kim, J.-W. Kim, J.-S. Kim, Influence of operation conditions and additives on the development of producer gas and tar reduction in air gasification of construction woody wastes using a two-stage gasifier, Bioresource technology 102 (2011) 7196-7203.

[88] A. Molino, S. Chianese, D. Musmarra, Biomass gasification technology: The state of the art overview, Journal of Energy Chemistry 25 (2016) 10-25.

[89] Y.-K. Choi, T.-Y. Mun, M.-H. Cho, J.-S. Kim, Gasification of dried sewage sludge in a newly developed three-stage gasifier: Effect of each reactor temperature on the producer gas composition and impurity removal, Energy 114 (2016) 121-128.

[90] S. Heidenreich, P.U. Foscolo, New concepts in biomass gasification, Progress in energy and combustion science 46 (2015) 72-95.

[91] I. Aigner, C. Pfeifer, H. Hofbauer, Co-gasification of coal and wood in a dual fluidized bed gasifier, Fuel 90 (2011) 2404-2412.

[92] N. Howaniec, A. Smoliński, K. Stańczyk, M. Pichlak, Steam co-gasification of coal and biomass derived chars with synergy effect as an innovative way of hydrogen-rich gas production, international journal of hydrogen energy 36 (2011) 14455-14463.

[93] M. Seggiani, M. Puccini, G. Raggio, S. Vitolo, Effect of sewage sludge content on gas quality and solid residues produced by cogasification in an updraft gasifier, Waste management 32 (2012) 1826-1834.

[94] Z. Ong, Y. Cheng, T. Maneerung, Z. Yao, Y.W. Tong, C.H. Wang, Y. Dai, Co - gasification of woody biomass and sewage sludge in a fixed - bed downdraft gasifier, AIChE Journal 61 (2015) 2508-2521.

[95] K.-W. Lee, W.C. Lee, H.J. Lee, J.I. Dong, Gasification characteristics of sewage sludge combined with wood biomass, Journal of Material Cycles and Waste Management 16 (2014) 642-649.

[96] I. Ahmed, A. Gupta, Hydrogen production from polystyrene pyrolysis and gasification: characteristics and kinetics, International journal of hydrogen energy 34 (2009) 6253-6264.

[97] I. Ahmed, A. Gupta, Syngas yield during pyrolysis and steam gasification of paper, Applied energy 86 (2009) 1813-1821.

[98] A. Midilli, M. Dogru, G. Akay, C.R. Howarth, Hydrogen production from sewage sludge via a fixed bed gasifier product gas, International Journal of Hydrogen Energy 27 (2002) 1035-1041.

[99] D. Suor, J. Ma, Z. Wang, Y. Li, J. Tang, Z. Wu, Enhanced power production from waste activated sludge in rotating-cathode microbial fuel cells: the effects of aquatic worm predation, Chemical Engineering Journal 248 (2014) 415-421.

[100] A. Rinaldi, B. Mecheri, V. Garavaglia, S. Licoccia, P. Di Nardo, E. Traversa, Engineering materials and biology to boost performance of microbial fuel cells: a critical review, Energy \& Environmental Science 1 (2008) 417-429.

[101] B.E. Logan, B. Hamelers, R. Rozendal, U. Schröder, J. Keller, S. Freguia, P. Aelterman, W. Verstraete, K. Rabaey, Microbial fuel cells: methodology and technology, Environmental science \& technology 40 (2006) 5181-5192.

[102] G. Zhang, Q. Zhao, Y. Jiao, K. Wang, D.-J. Lee, N. Ren, Efficient electricity generation from sewage sludge usingbiocathode microbial fuel cell, Water research 46 (2012) 43-52.

[103] J. Jiang, Q. Zhao, J. Zhang, G. Zhang, D.-J. Lee, Electricity generation from bio-treatment of sewage sludge with microbial fuel cell, Bioresource Technology 100 (2009) 5808-5812. 
[104] L. Borea, S. Puig, H. Monclús, V. Naddeo, J. Colprim, V. Belgiorno, Microbial fuel cell technology as a downstream process of a membrane bioreactor for sludge reduction, Chemical Engineering Journal (2017).

[105] Z. Wang, X. Mei, J. Ma, Z. Wu, Recent advances in microbial fuel cells integrated with sludge treatment, Chemical Engineering \& Technology 35 (2012) 1733-1743.

[106] S. Dentel, B. Strogen, P. Chiu, Direct generation of electricity from sludges and other liquid wastes, Water Science and Technology 50 (2004) 161-168.

[107] B. Xiao, F. Yang, J. Liu, Enhancing simultaneous electricity production and reduction of sewage sludge in two-chamber MFC by aerobic sludge digestion and sludge pretreatments, Journal of hazardous materials 189 (2011) 444-449.

[108] B. Xiao, M. Luo, X. Wang, Z. Li, H. Chen, J. Liu, X. Guo, Electricity production and sludge reduction by integrating microbial fuel cells in anoxic-oxic process, Waste Management 69 (2017) 346-352.

[109] A.N. Ghadge, D.A. Jadhav, H. Pradhan, M.M. Ghangrekar, Enhancing waste activated sludge digestion and power production using hypochlorite as catholyte in clayware microbial fuel cell, Bioresource technology 182 (2015) 225-231.

[110] G. Zhen, X. Lu, Y.-Y. Li, Y. Liu, Y. Zhao, Influence of zero valent scrap iron (ZVSI) supply on methane production from waste activated sludge, Chemical Engineering Journal 263 (2015) 461470.

[111] J. Jiang, Q. Zhao, L. Wei, K. Wang, D.-J. Lee, Degradation and characteristic changes of organic matter in sewage sludge using microbial fuel cell with ultrasound pretreatment, Bioresource technology 102 (2011) 272-277.

[112] J.-G. Lin, C.-N. Chang, S.-C. Chang, Enhancement of anaerobic digestion of waste activated sludge by alkaline solubilization, Bioresource Technology 62 (1997) 85-90.

[113] J. Jiang, Q. Zhao, K. Wang, L. Wei, G. Zhang, J. Zhang, Effect of ultrasonic and alkaline pretreatment on sludge degradation and electricity generation by microbial fuel cell, Water Science and Technology 61 (2010) 2915-2921.

[114] B. Xiao, F. Yang, J. Liu, Evaluation of electricity production from alkaline pretreated sludge using two-chamber microbial fuel cell, Journal of hazardous materials 254 (2013) 57-63.

[115] M.Z.M. Yusoff, A. Hu, C. Feng, T. Maeda, Y. Shirai, M.A. Hassan, C.-P. Yu, Influence of pretreated activated sludge for electricity generation in microbial fuel cell application, Bioresource technology 145 (2013) 90-96.

[116] Y. Yuan, Q. Chen, S. Zhou, L. Zhuang, P. Hu, Improved electricity production from sewage sludge under alkaline conditions in an insert - type air - cathode microbial fuel cell, Journal of Chemical Technology and Biotechnology 87 (2012) 80-86.

[117] S.-E. Oh, J.Y. Yoon, A. Gurung, D.-J. Kim, Evaluation of electricity generation from ultrasonic and heat/alkaline pretreatment of different sludge types using microbial fuel cells, Bioresource technology 165 (2014) 21-26.

[118] L. Cai, H. Zhang, Y. Feng, Y. Wang, M. Yu, Sludge decrement and electricity generation of sludge microbial fuel cell enhanced by zero valent iron, Journal of Cleaner Production (2017). [119] J.W. Judex, M. Gaiffi, H.C. Burgbacher, Gasification of dried sewage sludge: status of the demonstration and the pilot plant, Waste management 32 (2012) 719-723.

[120] A. Mountouris, E. Voutsas, D. Tassios, Plasma gasification of sewage sludge: Process development and energy optimization, Energy Conversion and Management 49 (2008) 22642271.

[121] E. Pokorna, N. Postelmans, P. Jenicek, S. Schreurs, R. Carleer, J. Yperman, Study of bio-oils and solids from flash pyrolysis of sewage sludges, Fuel 88 (2009) 1344-1350. 
[122] S. Sansaniwal, K. Pal, M. Rosen, S. Tyagi, Recent advances in the development of biomass gasification technology: A comprehensive review, Renewable and Sustainable Energy Reviews 72 (2017) 363-384.

[123] S. Ramachandran, Z. Yao, S. You, T. Massier, U. Stimming, C.-H. Wang, Life cycle assessment of a sewage sludge and woody biomass co-gasification system, Energy (2017). [124] X. Wang, Y. Feng, N. Ren, H. Wang, H. Lee, N. Li, Q. Zhao, Accelerated start-up of twochambered microbial fuel cells: effect of anodic positive poised potential, Electrochimica Acta 54 (2009) 1109-1114.

[125] D. Pant, G. Van Bogaert, L. Diels, K. Vanbroekhoven, A review of the substrates used in microbial fuel cells (MFCs) for sustainable energy production, Bioresource technology 101 (2010) 1533-1543.

[126] D. Nabarlatz, J. Vondrysova, P. Jenicek, F. Stüber, J. Font, A. Fortuny, A. Fabregat, C. Bengoa, Hydrolytic enzymes in activated sludge: extraction of protease and lipase by stirring and ultrasonication, Ultrasonics sonochemistry 17 (2010) 923-931.

[127] Y. Guanghui, H. Pinjing, S. Liming, Z. Yishu, Enzyme extraction by ultrasound from sludge flocs, Journal of Environmental Sciences 21 (2009) 204-210.

[128] A.D. Juwon, O.F. Emmanuel, Experimental investigations on the effects of carbon and nitrogen sources on concomitant amylase and polygalacturonase production by Trichoderma viride BITRS-1001 in submerged fermentation, Biotechnology research international 2012 (2012). [129] E. Bluemink, A. van Nieuwenhuijzen, E. Wypkema, C. Uijterlinde, Bio-plastic (poly-hydroxyalkanoate) production from municipal sewage sludge in the Netherlands: a technology push or a demand driven process?, Water Science and Technology 74 (2016) 353-358.

[130] S. Yan, S.B. Subramanian, R. Tyagi, R. Surampalli, Bioplastics from waste activated sludgebatch process, Practice periodical of hazardous, toxic, and radioactive waste management 12 (2008) 239-248.

[131] D. Baetens, A.-M. Aurola, A. Foglia, D. Dionisi, M. Van Loosdrecht, Gas chromatographic analysis of polyhydroxybutyrate in activated sludge: a round-robin test, Water science and technology 46 (2002) 357-361.

[132] E. Akaraonye, T. Keshavarz, I. Roy, Production of polyhydroxyalkanoates: the future green materials of choice, Journal of Chemical Technology and Biotechnology 85 (2010) 732-743.

[133] M.S. Kumar, S. Mudliar, K. Reddy, T. Chakrabarti, Production of biodegradable plastics from activated sludge generated from a food processing industrial wastewater treatment plant, Bioresource technology 95 (2004) 327-330.

[134] S. Mudliar, A. Vaidya, M.S. Kumar, S. Dahikar, T. Chakrabarti, Techno-economic evaluation of PHB production from activated sludge, Clean Technologies and Environmental Policy 10 (2008) 255-262.

[135] T. Pittmann, H. Steinmetz, Polyhydroxyalkanoate production as a side stream process on a municipal waste water treatment plant, Bioresource technology 167 (2014) 297-302.

[136] S. Longo, E. Katsou, S. Malamis, N. Frison, D. Renzi, F. Fatone, Recovery of volatile fatty acids from fermentation of sewage sludge in municipal wastewater treatment plants, Bioresource technology 175 (2015) 436-444.

[137] N. Frison, E. Katsou, S. Malamis, A. Oehmen, F. Fatone, Development of a novel process integrating the treatment of sludge reject water and the production of polyhydroxyalkanoates (PHAs), Environmental science \& technology 49 (2015) 10877-10885.

[138] Y. Jiang, Y. Chen, X. Zheng, Efficient polyhydroxyalkanoates production from a wasteactivated sludge alkaline fermentation liquid by activated sludge submitted to the aerobic feeding and discharge process, Environmental science \& technology 43 (2009) 7734-7741. 
[139] F. Morgan-Sagastume, A. Karlsson, P. Johansson, S. Pratt, N. Boon, P. Lant, A. Werker, Production of polyhydroxyalkanoates in open, mixed cultures from a waste sludge stream containing high levels of soluble organics, nitrogen and phosphorus, water research 44 (2010) 5196-5211.

[140] S. Bengtsson, A. Karlsson, T. Alexandersson, L. Quadri, M. Hjort, P. Johansson, F. MorganSagastume, S. Anterrieu, M. Arcos-Hernandez, L. Karabegovic, A process for polyhydroxyalkanoate ( $\mathrm{PHA}$ ) production from municipal wastewater treatment with biological carbon and nitrogen removal demonstrated at pilot-scale, New biotechnology 35 (2017) 42-53. [141] F. Morgan-Sagastume, M. Hjort, D. Cirne, F. Gerardin, S. Lacroix, G. Gaval, L. Karabegovic, T. Alexandersson, P. Johansson, A. Karlsson, Integrated production of polyhydroxyalkanoates (PHAs) with municipal wastewater and sludge treatment at pilot scale, Bioresource technology 181 (2015) 78-89.

[142] K. Sakai, S. Miyake, K. Iwama, D. Inoue, S. Soda, M. Ike, Polyhydroxyalkanoate (PHA) accumulation potential and PHA - accumulating microbial communities in various activated sludge processes of municipal wastewater treatment plants, Journal of applied microbiology 118 (2015) 255-266.

[143] N. Basset, E. Katsou, N. Frison, S. Malamis, J. Dosta, F. Fatone, Integrating the selection of PHA storing biomass and nitrogen removal via nitrite in the main wastewater treatment line, Bioresource technology 200 (2016) 820-829.

[144] N. Frison, E. Katsou, S. Malamis, A. Oehmen, F. Fatone, Nutrient removal via nitrite from reject water and polyhydroxyalkanoate (PHA) storage during nitrifying conditions, Journal of chemical technology and biotechnology 90 (2015) 1802-1810.

[145] T. Pittmann, H. Steinmetz, Potential for polyhydroxyalkanoate production on German or European municipal waste water treatment plants, Bioresource technology 214 (2016) 9-15. [146] V. Sanchis, D. Bourguet, Bacillus thuringiensis: Applications in agriculture and insect resistance management-A review, Sustainable Agriculture, Springer2009, pp. 243-255.

[147] L. Zhuang, S. Zhou, Y. Wang, Z. Liu, R. Xu, Cost-effective production of Bacillus thuringiensis biopesticides by solid-state fermentation using wastewater sludge: Effects of heavy metals, Bioresource technology 102 (2011) 4820-4826.

[148] P.F. Stanbury, A. Whitaker, S.J. Hall, Principles of fermentation technology, Elsevier2013.

[149] C.-H. Zhou, X. Xia, C.-X. Lin, D.-S. Tong, J. Beltramini, Catalytic conversion of lignocellulosic biomass to fine chemicals and fuels, Chemical Society Reviews 40 (2011) 5588-5617.

[150] R. Tyagi, R.Y. Surampalli, S. Yan, T.C. Zhang, C. Kao, B. Lohani, Sustainable sludge management: production of value added products, American Society of Civil Engineers, 2009.

[151] S.K. Brar, M. Verma, R. Tyagi, J. Valéro, R. Surampalli, Entomotoxicity, protease and chitinase activity of Bacillus thuringiensis fermented wastewater sludge with a high solids content, Bioresource technology 100 (2009) 4317-4325.

[152] M.T. Montiel, R. Tyagi, J. Valero, R. Surampalli, Production of biopesticides using wastewater sludge as a raw material-effect of process parameters, Water Science and Technology 48 (2003) 239-246.

[153] T. Pham, S. Brar, R. Tyagi, R. Surampalli, Optimization of Fenton oxidation pre-treatment for $B$. thuringiensis-based production of value added products from wastewater sludge, Journal of environmental management 91 (2010) 1657-1664.

[154] M.d.L.T. Montiel, R. Tyagi, J. Valero, Wastewater treatment sludge as a raw material for the production of Bacillus thuringiensis based biopesticides, Water Research 35 (2001) 38073816. 
[155] A. Vidyarthi, R. Tyagi, J. Valero, R. Surampalli, Studies on the production of B. thuringiensis based biopesticides using wastewater sludge as a raw material, Water Research 36 (2002) 48504860.

[156] A. Yezza, R.D. Tyagi, J.R. Valéro, R.Y. Surampalli, Wastewater sludge pre-treatment for enhancing entomotoxicity produced by Bacillus thuringiensis var. kurstaki, World Journal of Microbiology and Biotechnology 21 (2005) 1165.

[157] J. Zhou, Parker, W., Laha, S.,, Biosolids and Sludge Management, Water

Environment Research 79 (2007) 1496e1527.

[158] T. Pham, S.K. Brar, R. Tyagi, R. Surampalli, Ultrasonication of wastewater sludgeconsequences on biodegradability and flowability, Journal of hazardous materials 163 (2009) 891-898.

[159] Y. Yan, H. Chen, Q. He, X. Tan, X. Dai, Q. Zhou, Effect of ultrasonic time on waste activated sludge hydrolysis and volatile fatty acids accumulation under alkaline condition, Fresenius Environmental Bulletin 20 (2011) 2861-2868.

[160] R. Su, A. Hussain, J. Guo, J. Guan, Q. He, X. Yan, D. Li, Z. Guo, Animal feeds extracted from excess sludge by enzyme, acid and base hydrolysis processes, ACS Sustainable Chemistry \& Engineering 3 (2015) 2084-2091.

[161] J. Jimenez, F. Vedrenne, C. Denis, A. Mottet, S. Déléris, J.-P. Steyer, J.A.C. Rivero, A statistical comparison of protein and carbohydrate characterisation methodology applied on sewage sludge samples, Water research 47 (2013) 1751-1762.

[162] Y. Chen, S. Jiang, H. Yuan, Q. Zhou, G. Gu, Hydrolysis and acidification of waste activated sludge at different pHs, Water Research 41 (2007) 683-689.

[163] J. Hwang, L. Zhang, S. Seo, Y.-W. Lee, D. Jahng, Protein recovery from excess sludge for its use as animal feed, Bioresource technology 99 (2008) 8949-8954.

[164] M. Ras, E. Girbal-Neuhauser, E. Paul, M. Sperandio, D. Lefebvre, Protein extraction from activated sludge: an analytical approach, Water research 42 (2008) 1867-1878.

[165] I. Ribarova, S. Dimitrova, R. Lambeva, T. Wintgens, J. Stemann, K. Remmen, Phosphorus recovery potential in Sofia WWTP in view of the national sludge management strategy,

Resources, Conservation and Recycling 116 (2017) 152-159.

[166] W. Wong, W. Chan, P. Liao, K. Lo, D.S. Mavinic, Exploring the role of hydrogen peroxide in the microwave advanced oxidation process: solubilization of ammonia and phosphates, Journal of Environmental Engineering and Science 5 (2006) 459-465.

[167] K. Gorazda, B. Tarko, Z. Wzorek, H. Kominko, A.K. Nowak, J. Kulczycka, A. Henclik, M. Smol, Fertilisers production from ashes after sewage sludge combustion-A strategy towards sustainable development, Environmental Research 154 (2017) 171-180.

[168] $\mathrm{H}$. Kroiss, What is the potential for utilizing the resources in sludge?, Water Science and Technology 49 (2004) 1-10.

[169] H. Weigand, M. Bertau, W. Hübner, F. Bohndick, A. Bruckert, RecoPhos: Full-scale fertilizer production from sewage sludge ash, Waste management 33 (2013) 540-544.

[170] Z. Yuan, S. Pratt, D.J. Batstone, Phosphorus recovery from wastewater through microbial processes, Current opinion in biotechnology 23 (2012) 878-883.

[171] Y.-J. Shih, R.R.M. Abarca, M.D.G. de Luna, Y.-H. Huang, M.-C. Lu, Recovery of phosphorus from synthetic wastewaters by struvite crystallization in a fluidized-bed reactor: Effects of $\mathrm{pH}$, phosphate concentration and coexisting ions, Chemosphere 173 (2017) 466-473.

[172] D. Cordell, A. Rosemarin, J. Schröder, A. Smit, Towards global phosphorus security: A systems framework for phosphorus recovery and reuse options, Chemosphere 84 (2011) 747758. 
[173] Y. Jaffer, T. Clark, P. Pearce, S. Parsons, Potential phosphorus recovery by struvite formation, Water Research 36 (2002) 1834-1842.

[174] B. Cieślik, P. Konieczka, A review of phosphorus recovery methods at various steps of wastewater treatment and sewage sludge management. The concept of "no solid waste generation" and analytical methods, Journal of Cleaner Production (2017).

[175] X. Tao, X. HUANG, Releasing characteristics of phosphorus and other substances during thermal treatment of excess sludge, Journal of Environmental Sciences 19 (2007) 1153-1158. [176] Y. Wang, T. Zhang, P. Westerhoff, R. Jiang, H. Ren, Y. Yang, Z. Li, Microwave-assisted digestion and $\mathrm{NaOH}$ treatment of waste-activated sludge to recover phosphorus by crystallizing struvite, Environmental technology 38 (2017) 1211-1222.

[177] Z. Wzorek, M. Jodko, K. Gorazda, T. Rzepecki, Extraction of phosphorus compounds from ashes from thermal processing of sewage sludge, Journal of loss prevention in the process industries 19 (2006) 39-50.

[178] S. Donatello, C.R. Cheeseman, Recycling and recovery routes for incinerated sewage sludge ash (ISSA): A review, Waste Management 33 (2013) 2328-2340.

[179] S. Petzet, B. Peplinski, S. Bodkhe, P. Cornel, Recovery of phosphorus and aluminium from sewage sludge ash by a new wet chemical elution process (SESAL-Phos-recovery process), Water Science and Technology 64 (2011) 693-699.

[180] R. Li, W. Teng, Y. Li, W. Wang, R. Cui, T. Yang, Potential recovery of phosphorus during the fluidized bed incineration of sewage sludge, Journal of Cleaner Production 140 (2017) 964-970.

[181] P. Guedes, N. Couto, L.M. Ottosen, A.B. Ribeiro, Phosphorus recovery from sewage sludge ash through an electrodialytic process, Waste Management 34 (2014) 886-892.

[182] W.I. Chan, W.T. Wong, P.H. Liao, K.V. Lo, Sewage sludge nutrient solubilization using a single-stage microwave treatment, Journal of Environmental Science and Health Part A 42 (2007) 59-63.

[183] W.T. Wong, K.V. Lo, P.H. Liao, Factors affecting nutrient solubilization from sewage sludge using microwave-enhanced advanced oxidation process, Journal of Environmental Science and Health Part A 42 (2007) 825-829.

[184] Q. Yu, H. Lei, Z. Li, H. Li, K. Chen, X. Zhang, R. Liang, Physical and chemical properties of waste-activated sludge after microwave treatment, Water research 44 (2010) 2841-2849.

[185] N. Couto, P. Guedes, A.R. Ferreira, M.R. Teixeira, E.P. Mateus, A.B. Ribeiro, Electrodialytic Process of Nanofiltration Concentrates-Phosphorus Recovery and Microcystins Removal, Electrochimica Acta 181 (2015) 200-207.

[186] K. Stendahl, S. Jäfverström, Phosphate recovery from sewage sludge in combination with supercritical water oxidation, Water Science and Technology 48 (2003) 185-190.

[187] Y. Kalogo, H. Monteith, P. Eng, State of science report: energy and resource recovery from sludge, WERF, Water Environment Research Foundation2008.

[188] R. Prasad, A. Britton, B. Balzer, G. Schafran, Nutrient recovery by crystallization process: Virginia experience, Proceedings of the 80th annual technical exhibition and conference of the Water Environment Federation, 2007, pp. 356-358.

[189] Y. Ueno, M. Fujii, 3 years operating experience selling recovered struvite from full-scale plant, 2 nd international conference on recovery of phosphates from sewage and animal wastes. Noordwijkerhout, Holland.

[190] P. Roeleveld, P. Loeffen, H. Temmink, B. Klapwijk, Dutch analysis for P-recovery from municipal wastewater, Water Science and Technology 49 (2004) 191-199.

[191] B.M. Cieślik, J. Namieśnik, P. Konieczka, Review of sewage sludge management: standards, regulations and analytical methods, Journal of Cleaner Production 90 (2015) 1-15. 
[192] J. Havukainen, M.T. Nguyen, L. Hermann, M. Horttanainen, M. Mikkilä, I. Deviatkin, L. Linnanen, Potential of phosphorus recovery from sewage sludge and manure ash by thermochemical treatment, Waste Management 49 (2016) 221-229.

[193] S. Kataki, H. West, M. Clarke, D.C. Baruah, Phosphorus recovery as struvite: Recent concerns for use of seed, alternative Mg source, nitrogen conservation and fertilizer potential, Resources, Conservation and Recycling 107 (2016) 142-156.

[194] K. Zhou, M. Barjenbruch, C. Kabbe, G. Inial, C. Remy, Phosphorus recovery from municipal and fertilizer wastewater: China's potential and perspective, Journal of Environmental Sciences 52 (2017) 151-159.

[195] B. Nowak, P. Aschenbrenner, F. Winter, Heavy metal removal from sewage sludge ash and municipal solid waste fly ash-a comparison, Fuel processing technology 105 (2013) 195-201.

[196] R.D. Tyagi, J.-F. Blais, J.-C. Auclair, N. Meunier, Bacterial leaching of toxic metals from municipal sludge: influence of sludge characteristics, Water environment research 65 (1993) 196-204.

[197] H. Saveyn, J. Ferrasse, A. Hernandez, J. Rose, P. Van Der Meeren, N. Roche, The distribution of heavy metals following sewage sludge gasification, Journal of Residuals Science \& Technology 8 (2011).

[198] Y. He, Y. Zhai, C. Li, F. Yang, L. Chen, X. Fan, W. Peng, Z. Fu, The fate of Cu, Zn, Pb and Cd during the pyrolysis of sewage sludge at different temperatures, Environmental technology 31 (2010) 567-574.

[199] A. Nzihou, B. Stanmore, The fate of heavy metals during combustion and gasification of contaminated biomass - a brief review, Journal of hazardous materials 256 (2013) 56-66.

[200] S. Werle, M. Dudziak, Analysis of organic and inorganic contaminants in dried sewage sludge and by-products of dried sewage sludge gasification, Energies 7 (2014) 462-476.

[201] I. Hwang, Y. Ouchi, T. Matsuto, Characteristics of leachate from pyrolysis residue of sewage sludge, Chemosphere 68 (2007) 1913-1919.

[202] R.C. Kistler, F. Widmer, P.H. Brunner, Behavior of chromium, nickel, copper, zinc, cadmium, mercury, and lead during the pyrolysis of sewage sludge, Environmental science \& technology 21 (1987) 704-708.

[203] T. Lu, H. Yuan, Y. Wang, H. Huang, Y. Chen, Characteristic of heavy metals in biochar derived from sewage sludge, Journal of Material Cycles and Waste Management 18 (2016) 725733.

[204] H. Wu, P. Glarborg, F.J. Frandsen, K. Dam-Johansen, P.A. Jensen, B. Sander, Trace elements in co-combustion of solid recovered fuel and coal, Fuel processing technology 105 (2013) 212221.

[205] L. Li, Z. Xu, C. Zhang, J. Bao, X. Dai, Quantitative evaluation of heavy metals in solid residues from sub-and super-critical water gasification of sewage sludge, Bioresource technology 121 (2012) 169-175.

[206] Y. Hu, G. Chen, W. Ma, M. Yan, L. Han, Distribution and Contamination Hazards of Heavy Metals in Solid Residues from the Pyrolysis and Gasification of Wastewater Sewage Sludge, Journal of Residuals Science \& Technology 13 (2016).

[207] T. Wang, Y. Xue, M. Zhou, Y. Yuan, S. Zhao, G. Tan, X. Zhou, J. Geng, S. Wu, H. Hou, Comparative study on the mobility and speciation of heavy metals in ashes from co-combustion of sewage sludge/dredged sludge and rice husk, Chemosphere 169 (2017) 162-170.

[208] M. Stals, E. Thijssen, J. Vangronsveld, R. Carleer, S. Schreurs, J. Yperman, Flash pyrolysis of heavy metal contaminated biomass from phytoremediation: influence of temperature, entrained flow and wood/leaves blended pyrolysis on the behaviour of heavy metals, Journal of Analytical and Applied Pyrolysis 87 (2010) 1-7. 
[209] H. Cui, S.Q. Turn, V. Keffer, D. Evans, T. Tran, M. Foley, Study on the fate of metal elements from biomass in a bench-scale fluidized bed gasifier, Fuel 108 (2013) 1-12.

[210] J.A. Tafur-Marinos, M. Ginepro, L. Pastero, A. Torazzo, E. Paschetta, D. Fabbri, V. Zelano, Comparison of inorganic constituents in bottom and fly residues from pelletised wood pyrogasification, Fuel 119 (2014) 157-162.

[211] M. Šyc, M. Pohořelý, M. Jeremiáš, M. Vosecký, P. Kameníková, S. Skoblia, K. Svoboda, M. Punčochár̆, Behavior of heavy metals in steam fluidized bed gasification of contaminated biomass, Energy \& Fuels 25 (2011) 2284-2291.

[212] J. Shao, X. Yuan, L. Leng, H. Huang, L. Jiang, H. Wang, X. Chen, G. Zeng, The comparison of the migration and transformation behavior of heavy metals during pyrolysis and liquefaction of municipal sewage sludge, paper mill sludge, and slaughterhouse sludge, Bioresource technology 198 (2015) 16-22.

[213] R. Mailler, J. Gasperi, D. Patureau, E. Vulliet, N. Delgenes, A. Danel, S. Deshayes, V. Eudes, S. Guerin, R. Moilleron, Fate of emerging and priority micropollutants during the sewage sludge treatment: Case study of Paris conurbation. Part 1: Contamination of the different types of sewage sludge, Waste Management 59 (2017) 379-393.

[214] V.G. Samaras, A.S. Stasinakis, N.S. Thomaidis, D. Mamais, T.D. Lekkas, Fate of selected emerging micropollutants during mesophilic, thermophilic and temperature co-phased anaerobic digestion of sewage sludge, Bioresource technology 162 (2014) 365-372.

[215] B.O. Clarke, S.R. Smith, Review of 'emerging'organic contaminants in biosolids and assessment of international research priorities for the agricultural use of biosolids, Environment international 37 (2011) 226-247.

[216] F. Chen, G.-G. Ying, Y.-B. Ma, Z.-F. Chen, H.-J. Lai, F.-J. Peng, Field dissipation and risk assessment of typical personal care products TCC, TCS, AHTN and HHCB in biosolid-amended soils, Science of the Total Environment 470 (2014) 1078-1086.

[217] L. Barron, E. Nesterenko, K. Hart, E. Power, B. Quinn, B. Kelleher, B. Paull, Holistic visualisation of the multimodal transport and fate of twelve pharmaceuticals in biosolid enriched topsoils, Analytical and bioanalytical chemistry 397 (2010) 287-296.

[218] N. Paterakis, T. Chiu, Y. Koh, J. Lester, E. McAdam, M. Scrimshaw, A. Soares, E. Cartmell, The effectiveness of anaerobic digestion in removing estrogens and nonylphenol ethoxylates, Journal of hazardous materials 199 (2012) 88-95.

[219] J. Malmborg, J. Magnér, Pharmaceutical residues in sewage sludge: effect of sanitization and anaerobic digestion, Journal of environmental management 153 (2015) 1-10.

[220] T. De Mes, K. Kujawa-Roeleveld, G. Zeeman, G. Lettinga, Anaerobic biodegradation of estrogens-hard to digest, Water Science and Technology 57 (2008) 1177-1182.

[221] T. Alvarino, S. Suarez, J. Lema, F. Omil, Understanding the removal mechanisms of PPCPs and the influence of main technological parameters in anaerobic UASB and aerobic CAS reactors, Journal of hazardous materials 278 (2014) 506-513.

[222] M. Clara, O. Gans, G. Windhofer, U. Krenn, W. Hartl, K. Braun, S. Scharf, C. Scheffknecht, Occurrence of polycyclic musks in wastewater and receiving water bodies and fate during wastewater treatment, Chemosphere 82 (2011) 1116-1123.

[223] M. Narumiya, N. Nakada, N. Yamashita, H. Tanaka, Phase distribution and removal of pharmaceuticals and personal care products during anaerobic sludge digestion, Journal of hazardous materials 260 (2013) 305-312.

[224] M. Carballa, F. Omil, T. Ternes, J.M. Lema, Fate of pharmaceutical and personal care products (PPCPs) during anaerobic digestion of sewage sludge, Water Research 41 (2007) 21392150. 
[225] W. Huang, F. Gong, M. Fan, Q. Zhai, C. Hong, Q. Li, Production of light olefins by catalytic conversion of lignocellulosic biomass with HZSM-5 zeolite impregnated with 6wt.\% lanthanum, Bioresource technology 121 (2012) 248-255.

[226] S. Xia, G.A. Baker, H. Li, S. Ravula, H. Zhao, Aqueous ionic liquids and deep eutectic solvents for cellulosic biomass pretreatment and saccharification, RSC advances 4 (2014) 1058610596.

[227] I. Adeyemi, I. Janajreh, T. Arink, C. Ghenai, Gasification behavior of coal and woody biomass: Validation and parametrical study, Applied Energy 185 (2017) 1007-1018.

[228] S.-W. Park, C.-H. Jang, K.-R. Baek, J.-K. Yang, Torrefaction and low-temperature carbonization of woody biomass: evaluation of fuel characteristics of the products, Energy 45 (2012) 676-685.

[229] T. Wang, Y. Zhai, Y. Zhu, C. Peng, B. Xu, T. Wang, C. Li, G. Zeng, Acetic Acid and Sodium Hydroxide-Aided Hydrothermal Carbonization of Woody Biomass for Enhanced Pelletization and Fuel Properties, Energy \& Fuels 31 (2017) 12200-12208.

[230] F. Xu, J. Sun, N.M. Konda, J. Shi, T. Dutta, C.D. Scown, B.A. Simmons, S. Singh, Transforming biomass conversion with ionic liquids: process intensification and the development of a highgravity, one-pot process for the production of cellulosic ethanol, Energy \& Environmental Science 9 (2016) 1042-1049.

[231] S.M. Kim, B.S. Dien, V. Singh, Promise of combined hydrothermal/chemical and mechanical refining for pretreatment of woody and herbaceous biomass, Biotechnology for biofuels 9 (2016) 97.

[232] D.C. Kalyani, T. Fakin, S.J. Horn, R. Tschentscher, Valorisation of woody biomass by combining enzymatic saccharification and pyrolysis, Green Chemistry (2017).

[233] C. Lorenzetti, R. Conti, D. Fabbri, J. Yanik, A comparative study on the catalytic effect of HZSM5 on upgrading of pyrolysis vapors derived from lignocellulosic and proteinaceous biomass, Fuel 166 (2016) 446-452.

[234] K. Servaes, A. Varhimo, M. Dubreuil, M. Bulut, P. Vandezande, M. Siika-aho, J. Sirviö, K. Kruus, W. Porto-Carrero, B. Bongers, Purification and concentration of lignin from the spent liquor of the alkaline oxidation of woody biomass through membrane separation technology, Industrial Crops and Products (2016).

[235] G. Yildiz, F. Ronsse, R. van Duren, W. Prins, Challenges in the design and operation of processes for catalytic fast pyrolysis of woody biomass, Renewable and Sustainable Energy Reviews 57 (2016) 1596-1610.

[236] K. Zhang, Z. Pei, D. Wang, Organic solvent pretreatment of lignocellulosic biomass for biofuels and biochemicals: a review, Bioresource technology 199 (2016) 21-33.

[237] J. Singh, M. Suhag, A. Dhaka, Augmented digestion of lignocellulose by steam explosion, acid and alkaline pretreatment methods: a review, Carbohydrate Polymers 117 (2015) 624-631. [238] J. Yoder, S. Galinato, D. Granatstein, M. Garcia-Pérez, Economic tradeoff between biochar and bio-oil production via pyrolysis, biomass and bioenergy 35 (2011) 1851-1862.

[239] L. Yang, F. Xu, X. Ge, Y. Li, Challenges and strategies for solid-state anaerobic digestion of lignocellulosic biomass, Renewable and Sustainable Energy Reviews 44 (2015) 824-834.

[240] M. FitzPatrick, P. Champagne, M.F. Cunningham, R.A. Whitney, A biorefinery processing perspective: treatment of lignocellulosic materials for the production of value-added products, Bioresource technology 101 (2010) 8915-8922.

[241] Y.-X. An, M.-H. Zong, H. Wu, N. Li, Pretreatment of lignocellulosic biomass with renewable cholinium ionic liquids: Biomass fractionation, enzymatic digestion and ionic liquid reuse, Bioresource technology 192 (2015) 165-171. 
[242] Z. Pavlík, J. Fořt, M. Záleská, M. Pavlíková, A. Trník, I. Medved, M. Keppert, P.G.

Koutsoukos, R. Černý, Energy-efficient thermal treatment of sewage sludge for its application in blended cements, Journal of Cleaner Production 112 (2016) 409-419.

[243] M. Smol, J. Kulczycka, A. Henclik, K. Gorazda, Z. Wzorek, The possible use of sewage sludge ash (SSA) in the construction industry as a way towards a circular economy, Journal of Cleaner Production 95 (2015) 45-54.

[244] S. Paul, A. Dutta, Challenges and opportunities of lignocellulosic biomass for anaerobic digestion, Resources, Conservation and Recycling 130 (2018) 164-174.

[245] K.-Y. Chiang, C.-H. Lu, C.-K. Liao, R.H.-R. Ger, Characteristics of hydrogen energy yield by co-gasified of sewage sludge and paper-mill sludge in a commercial scale plant, International Journal of Hydrogen Energy 41 (2016) 21641-21648.

[246] E. Taarning, C.M. Osmundsen, X. Yang, B. Voss, S.I. Andersen, C.H. Christensen, Zeolitecatalyzed biomass conversion to fuels and chemicals, Energy \& Environmental Science 4 (2011) 793-804.

[247] C. Lievens, R. Carleer, T. Cornelissen, J. Yperman, Fast pyrolysis of heavy metal contaminated willow: Influence of the plant part, Fuel 88 (2009) 1417-1425.

[248] X. Wang, S. Deng, H. Tan, A. Adeosun, M. Vujanović, F. Yang, N. Duić, Synergetic effect of sewage sludge and biomass co-pyrolysis: a combined study in thermogravimetric analyzer and a fixed bed reactor, Energy Conversion and Management 118 (2016) 399-405.

[249] S. Karlsson, L.-E. Åmand, J. Liske, Reducing high-temperature corrosion on high-alloyed stainless steel superheaters by co-combustion of municipal sewage sludge in a fluidised bed boiler, Fuel 139 (2015) 482-493.

[250] Z. Xiao, X. Yuan, L. Jiang, X. Chen, H. Li, G. Zeng, L. Leng, H. Wang, H. Huang, Energy recovery and secondary pollutant emission from the combustion of co-pelletized fuel from municipal sewage sludge and wood sawdust, Energy 91 (2015) 441-450.

[251] Y. Zhai, Z. Chen, H. Chen, B. Xu, P. Li, R. Qing, C. Li, G. Zeng, Co-liquefaction of sewage sludge and oil-tea-cake in supercritical methanol: yield of bio-oil, immobilization and risk assessment of heavy metals, Environmental technology 36 (2015) 2770-2777.

[252] A.C. Johnson, J.P. Sumpter, Improving the quality of wastewater to tackle trace organic contaminants: think before you act!, ACS Publications, 2015.

[253] EC, (European Commission): Economic and Social Impacts of the Use of Sewage Sludge on Land 2008.

[254] CEU, (Council of the European Union): Council Directive of 26 April 1999, on the landfill of waste (99/31/EC), Official Journal of the European Union 1999, pp. 1-19.

[255] A. Willén, C. Junestedt, L. Rodhe, M. Pell, H. Jönsson, Sewage sludge as fertiliserenvironmental assessment of storage and land application options, Water Science and Technology (2016) wst2016584.

[256] A. Christodoulou, K. Stamatelatou, Overview of legislation on sewage sludge management in developed countries worldwide, Water Science and Technology 73 (2016) 453-462.

[257] M. Van de Velden, R. Dewil, J. Baeyens, L. Josson, P. Lanssens, The distribution of heavy metals during fluidized bed combustion of sludge (FBSC), Journal of Hazardous Materials 151 (2008) 96-102.

[258] J. Lederer, H. Rechberger, Comparative goal-oriented assessment of conventional and alternative sewage sludge treatment options, Waste Management 30 (2010) 1043-1056.

[259] A.K. Venkatesan, H.Y. Done, R.U. Halden, United States National Sewage Sludge Repository at Arizona State University-a new resource and research tool for environmental scientists, engineers, and epidemiologists, Environmental Science and Pollution Research 22 (2015) 15771586. 
[260] N. Beecher, K. Crawford, N. Goldstein, G. Kester, M. Lono-Batura, E. Dziezyk, A national biosolids regulation, quality, end use and disposal survey, Tamworth, NH: North East Biosolids and Residuals Association (2007).

[261] USDA, Fertilizer Use and Price, (http://www.ers.usda.gov/dataproducts/fertilizer-use-andprice.aspx), U.S. Department of Agriculture

Economic Research Service, 2015.

[262] P.L. McCarty, J. Bae, J. Kim, Domestic wastewater treatment as a net energy producer-can this be achieved?, Environ. Sci. Technol. 45 (2011) 7100-7106.

[263] L. Feng, J. Luo, Y. Chen, Dilemma of sewage sludge treatment and disposal in China, ACS Publications, 2015.

[264] W. Wang, Y. Luo, W. Qiao, Possible solutions for sludge dewatering in China, Frontiers of Environmental Science \& Engineering in China 4 (2010) 102-107.

[265] Z. Wang, Zhang, Sha, The present situation and research progress of treatment of sludge from city sewage treatment plant., Tianjin Daxue Xuebao 30. (2015).

[266] L. Jin, G. Zhang, H. Tian, Current state of sewage treatment in China, Water research 66 (2014) 85-98.

[267] K. Zhou, M. Barjenbruch, C. Kabbe, G. Inial, C. Remy, Phosphorus recovery from municipal and fertilizer wastewater: China's potential and perspective, Journal of Environmental Sciences (2016). 